UNIVERSIDADE DE SÃO PAULO

FACULDADE DE MEDICINA DE RIBEIRÃO PRETO

DEPARTAMENTO DE GENÉTICA

\title{
As rotas de dispersão de Drosophila buzzatii na América do Sul
}

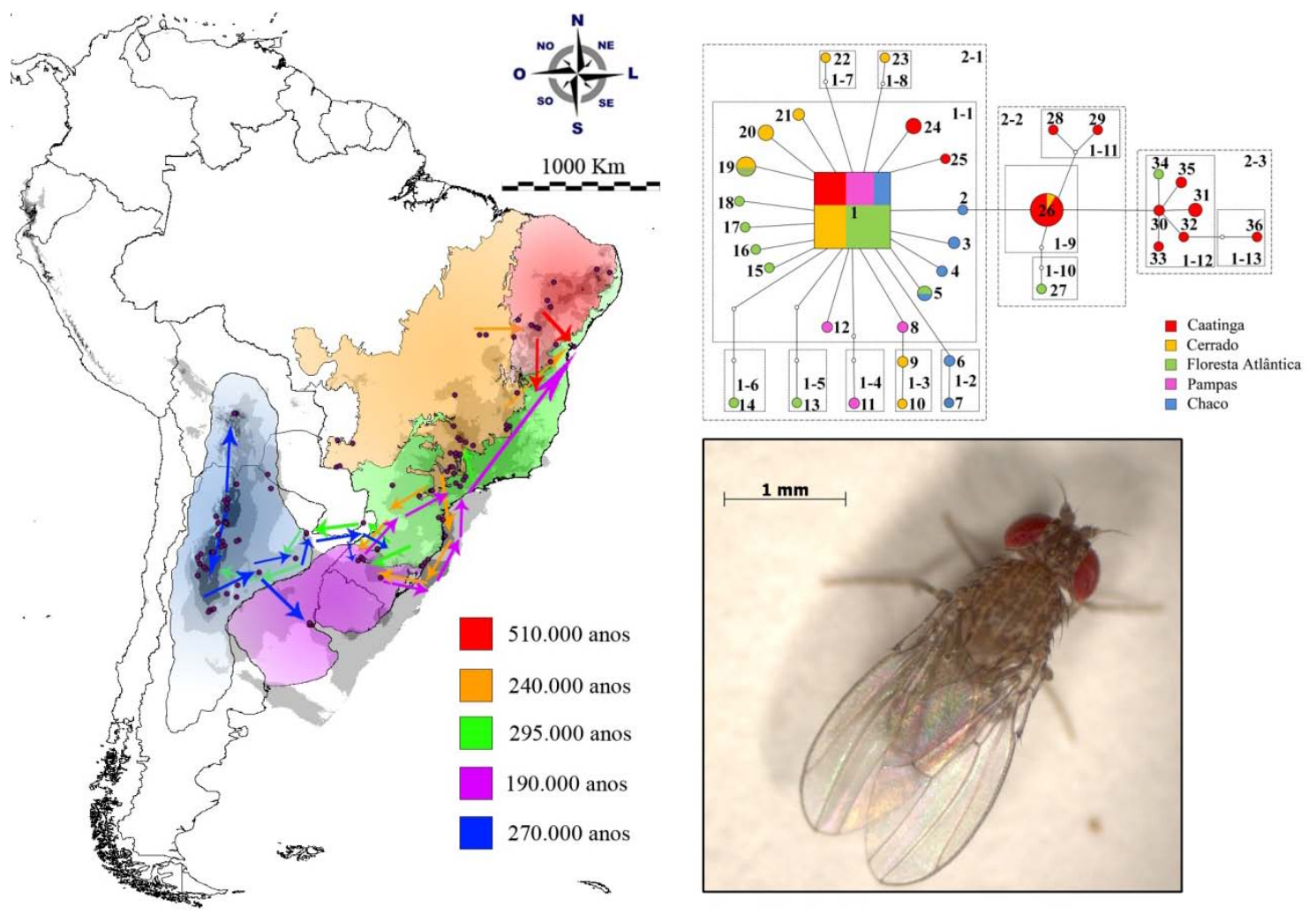

Movimentos migratórios, NCPA e foto de Drosophila buzzatii.

\section{MATEUS HENRIQUE SANTOS}




\title{
As rotas de dispersão de Drosophila buzzatii na América do Sul
}

\section{MATEUS HENRIQUE SANTOS}

\author{
Tese de Doutorado apresentada ao Departamento \\ de Genética da Faculdade de Medicina de \\ Ribeirão Preto-USP, como parte dos requisitos \\ para obtenção do título de Doutor em Ciências \\ Área de Concentração: Genética
}

Orientadora: $\operatorname{Prof}^{\mathrm{a}}$. Dr ${ }^{\mathrm{a}}$. Maura Helena Manfrin 
Autorizo a reprodução total ou parcial deste trabalho para fins de estudo didático e científico, desde que citada a fonte.

\section{FICHA CATALOGRÁFICA}

Santos, Mateus Henrique

As rotas de dispersão de Drosophila buzzatii na América do Sul.

Mateus Henrique Santos; orientador: Maura Helena Manfrin. Ribeirão Preto, 2011.

128p.: 28 il.

Tese de Doutorado, apresentada à Faculdade de Medicina de Ribeirão Preto/USP. Área de concentração: Genética.

1. Filogeografia. 2. Gene COI. 3. Drosophila buzzatii. 4. Modelagem de Nicho Ecológico. 5. Rotas de Dispersão. 6. Eventos de Glaciação. 
Este trabalho foi realizado com auxílio financeiro da CAPES - Coordenação de Aperfeiçoamento de Pessoal de Nível Superior através do Programa de Demanda Social do Departamento de Genética da FMRP-USP 


\section{FOLHA DE APROVAÇÃO}

Mateus Henrique Santos

Título da Tese: Filogeografia e genética de populações da espécie Drosophila buzzatii (Diptera, Drosophilidae).

Tese de Doutorado apresentada ao Departamento de Genética da Faculdade de Medicina de Ribeirão Preto-USP, como parte dos requisitos para obtenção do título de Doutor em Ciências

Área de Concentração: Genética

Aprovado em:

Banca Examinadora

Prof. Dr.

Instituição:

Assinatura:

Prof. Dr.

Instituição:

Assinatura:

Prof. Dr.

Instituição:

Assinatura:

Prof. Dr.

Instituição:

Assinatura:

Prof. Dr.

Instituição: Assinatura: 
Dedico à minha companheira Rafaela Lopes Falaschi e minha Mãe Maria Antonieta Marangon Santos. 


\section{AGRADECIMENTOS}

À Prof ${ }^{\mathrm{a}}$. Dr ${ }^{\mathrm{a}}$. Maura Helena Manfrin (FFCLRP/USP) pela oportunidade de poder trabalhar com um grupo tão interessante, pela amizade, confiança e paciência, não só pelas minhas eventuais cabeçadas e trapalhadas, mas por compartilhar com muito bom humor das minhas histórias bizarras.

Ao Prof. Dr. Fábio de Melo Sene (FMRP/USP) por todo o conhecimento adquirido em discussões, dentro e fora do laboratório, pela ajuda em muitos momentos e pelas maravilhosas histórias compartilhadas nos cafés do laboratório.

À Prof ${ }^{\mathrm{a}}$. Dr ${ }^{\mathrm{a}}$. Nilce Martinez Rossi (FMRP/USP) por ter disponibilizado os equipamentos do seu laboratório para realização de várias etapas práticas deste trabalho.

Ao Prof. Dr. Ademilson Espencer Egea Soares (FMRP/USP) pela atenção e pelo excelente trabalho que realiza na coordenação do Departamento de Genética, em especial, durante o Curso de Verão, o qual eu tive o privilégio de trabalhar em sua companhia.

Ao Prof. Dr. Esteban Ruben Hasson (UBA) pela orientação durante o estágio “sanduíche” realizado na Universidad de Buenos Aires em 2008.

Ao Prof. Dr. Reinaldo O. A. A. de Brito (UFSCar) por disponibilizar várias sequências utilizadas neste trabalho e por compartilhar momentos de discussão muito proveitosos.

Ao Prof. Dr. Iderval da Silva Junior Sobrinho(UFSCar), pelas discussões sobre estatística e evolução.

Ao Prof. Dr. Fernando de Faria Franco (UFSCar-Sorocaba), pelas discussões sobre genética, evolução e estatística, pela inspiração que sua tese me proporcionou, por disponibilizar sempre que necessário seu tempo e amostras, pelo companheirismo e auxílio na coleta pelos estados da Paraíba e Ceará em 2007, pela companhia durante nossos cursos na UFSCar e por compartilhar da minha admiração pela obra máxima de Senhor Jorge Lucas, “Que a força esteja com você!”.

À minha companheira Rafaela Lopes Falaschi, pelo amor compartilhado, não só um pelo outro, mas pela biologia e ensino de um modo geral, pela sua paciência, 
dedicação e ajuda sempre que necessário, pelas broncas na hora certa e por nunca “deixar a peteca cair” nas horas mais difíceis e por compartilhar dos momentos bons e ruins das nossas vidas.

À minha mãe Maria Antonieta Marangon Santos, que sempre me deu apoio e suporte em todos os momentos da minha vida, dos fáceis aos difíceis, sendo sempre essa pessoa maravilhosa e fora da curva normal a qual eu só tenho que agradecer.

À minha irmã, Anelisa Santos, pelas caronas e também por mostrar um lado da vida totalmente oposto ao meu, não me deixando ir para o lado negro da força.

Ao Prof. Dr. Dalton de Souza Amorim (FFCLRP/USP), por gentilmente ceder o espaço do seu laboratório sempre que foi preciso para a confecção desta tese e também pelas discussões sobre biogeografia e sistemática, por vezes calorosa, mas sempre muito proveitosas.

À minha segunda mãe, Maria Isabel Protti de Andrade Balbi, pelo apoio e suporte nos momentos mais difíceis, pelos ensinamentos que levarei para minha vida e por compartilhar seu carinho e trazer luz aos lugares mais escuros.

Aos amigos do Laboratório de Genética Evolutiva, Luis E. M. Bizzo, Camila K. B. Santos, Cintia G. Santos, Rafael F. Ferreira, Érica C. C. Silva, Fernando de F. Franco, Gislaine Angélica R. Silva, Carla Fernanda B. Cavallari, Thaís Lavagnini, Paulo R. Epifánio, Pedro R. R. Prado e Rogério P. Mateus pela convivência agradável, suporte, companheirismo e ótimos momentos que passamos juntos, por vezes rindo ou discutindo biologia, política e outros temas.

Ao Técnico Mendelson Mazucato (FMRP/USP) pela ajuda indispensável durante o processo de seqüenciamento, pela amizade e excelente convivência.

Aos meus amigos Renato S. Capellari (Lazarento), Paula R. Riccardi (Íngua), Diego A. Fachin (Garfo), Danilo C. Ament (Joel), Marcella F. Amorim (Tuiu), Vanessa N. Roma, Felipe A. Ribeiro (Lixa), Priscila B. Okano (Xaxinha), André F. D. Micas (Dedé), Melíssa Bars (Mel), Eduardo Ledvinka Filho (Nikito), Agnes A. S. Takeda (Nhanhes), Renato N. Soriano (Gorfo), Mariana Galera Soler (Má Galera), Ana Durvalina Bomtorin (Tita) pela convivência, amizade, companheirismo, discussões 
sobre os mais variados temas, por muitas vezes compartilhado nas mesas de bar, no Restaurante Universitário da USP, na cantina do “Seu Zé” ou outros lugares.

À minha sogra Raquel Lopes da Silva Falaschi, meu sogro Luiz Falaschi, meu cunhado Caio César Lopes Falaschi, pela amizade e apoio em todos os momentos da minha vida.

À todos os demais amigos, colegas e familiares que me esqueci de mencionar, não por maldade ou descuido, mas pela minha incapacidade de me lembrar do nome de todas as pessoas que estiveram presentes nesta fase da minha vida, sei que aqueles que me conhecem bem me perdoarão por este deslize, pois sabem muito bem que eu memorizo muito bem trechos enormes dos livros do J. R. R. Tolkien, Douglas N. Adams e até as regras necessárias a sobrevivência em caso do mundo ser tomado por Zumbis, mas sou incapaz de lembrar qual o número de telefone da casa da minha sogra, a todos vocês minhas mais sinceras desculpas.

À CAPES, pela concessão da bolsa de doutorado.

Ao Departamento de Genética da FMRP/USP, seus funcionários e secretárias que estão sempre disponíveis para nos ajudar com as pendências burocráticas existentes no mundo acadêmico, pela disponibilização dos recursos e espaço físico para a realização deste trabalho.

À CAPES, FINEP, FAPESP, CNPq e USP, cujas verbas mantêm o Laboratório de Genética Evolutiva.

À todos meu muito obrigado. 


\section{Sumário}

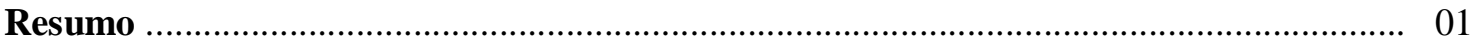

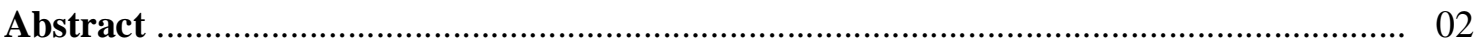

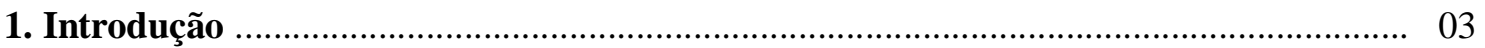

1.1 Estrutura de populações e filogeografia .......................................................................... 03

1.2 O “Cluster” Drosophila buzzatii e a espécie Drosophila buzzatii ................................... 04

1.3 Flutuações climáticas e rotas de dispersão da vegetação na América do Sul ................. 09

1.4 Domínios fitogeográficos .......................................................................................... 12

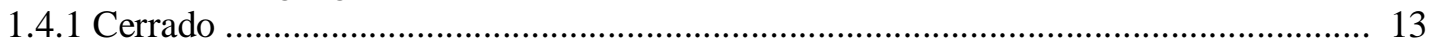

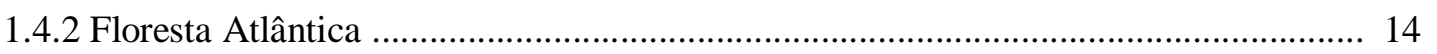

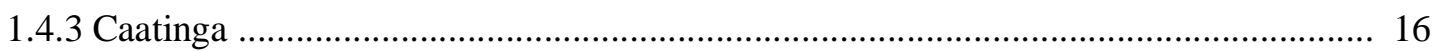

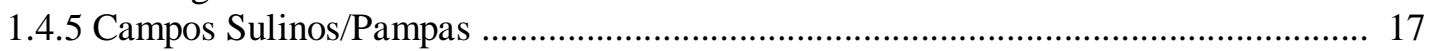

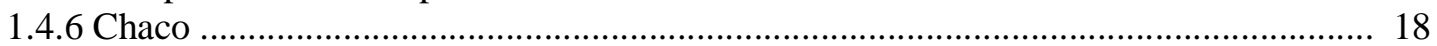

1.5 Disjunções dos Domínios Fitogeográficos ............................................................... 19

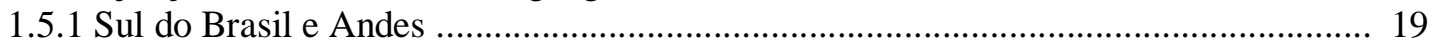

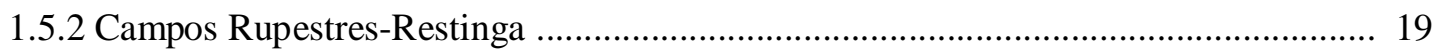

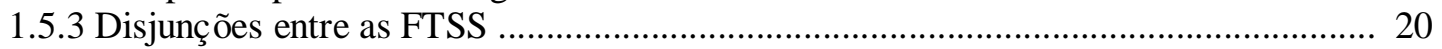

1.5.4 Disjunção entre afloramentos rochosos na Floresta Atântica e montanhas no

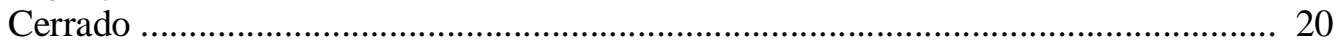

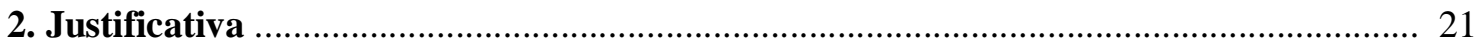

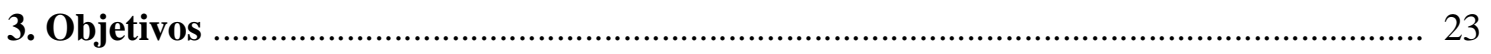

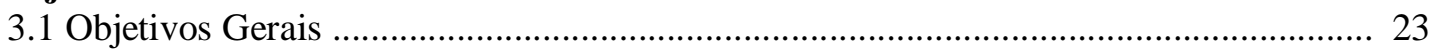

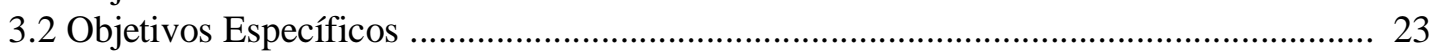

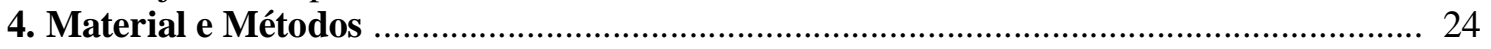

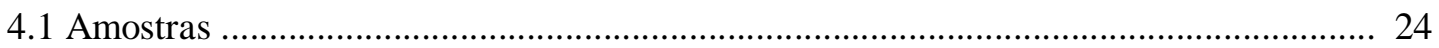

4.2 Extração de DNA ....................................................................................................... 24

4.3 Amplificação e isolamento do Gene Mitocondrial Citocromo Oxidase I (COI) ........... 27

4.4 Purificação dos Produtos de PCR ............................................................................... 27

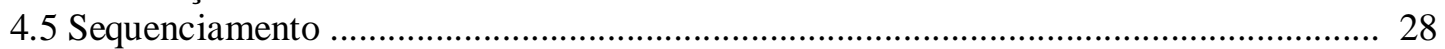

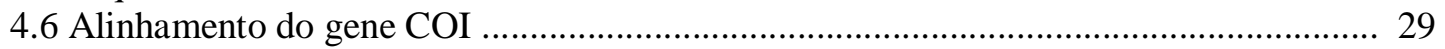

4.7 Análises estatísticas do gene COI ................................................................................. 29

4.8 Índices de diversidade, testes de neutralidade e estimativa do tempo de

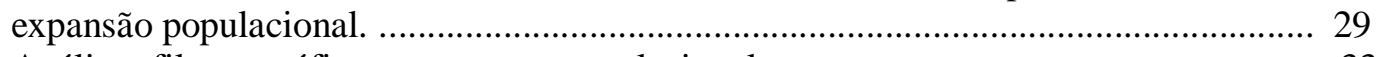

4.9 Análises filogeográficas e estrutura populacional ........................................................... 33

4.10 Modelagem de nicho ecológico e Paleomodelagem .................................................. 36

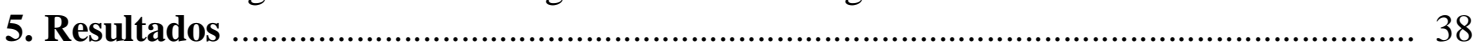

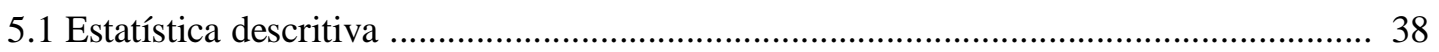

5.2 Rede de haplótipos e Nested Clade Phylogeographic Analysis (NCPA) ........................ 39

5.3 Estruturação populacional AMOVA e Fst ................................................................. 40

5.4 Testes de Neutralidade e Mismatch Distribution ............................................................ 44

5.5 Estimativas do tempo de expansão populacional ............................................................ 48

5.5.1 Mismatch Distribution e Inferência Bayesiana ........................................................... 48

5.5.2 Estimativas do sentido dos movimentos de expansão populacional ........................... 49

5.6 Resultados da modelagem de nicho ecológico .............................................................. 50

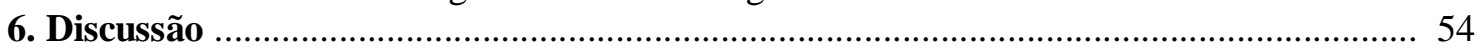

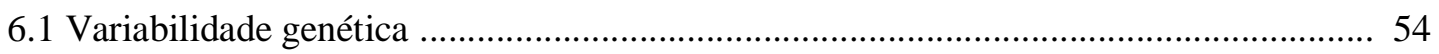

6.2 Estruturação populacional, NCPA e teste de Mantel .................................................... 56

6.3 Modelagem de Nicho Ecológico e paleomodelagem .................................................... 59

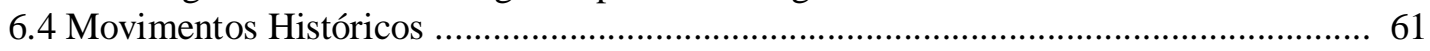

6.4.1 Movimentos a partir do domínio da Caatinga .......................................................... 62

6.4.2 Movimentos a partir do domínio da Floresta Atlântica ................................................. 67 
6.4.3 Movimentos a partir do domínio do Chaco .................................................................... 69

6.4.4 Movimentos a partir do domínio do Cerrado ............................................................... 71

6.4.5 Movimentos a partir do domínio dos Pampas ............................................................. 74

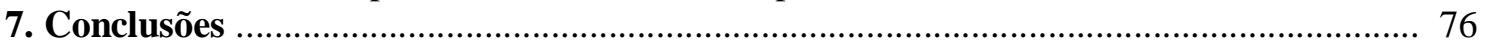

8. Referências Bibliográficas ...................................................................................... 77

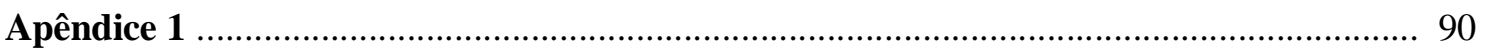

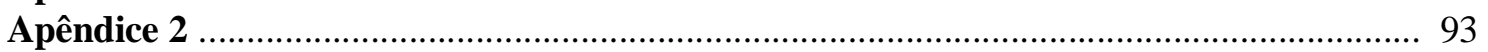

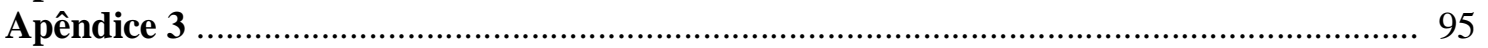

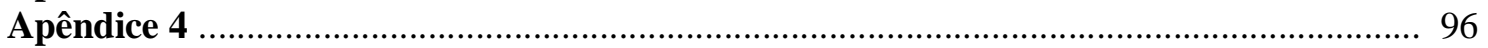




\title{
As rotas de dispersão de Drosophila buzzatii na América do Sul
}

\author{
Santos, M. H.
}

\section{Resumo}

Drosophila buzzatii é uma espécie cactófila associada a diferentes espécies de cactos e distribuída nos diferentes Domínios fitogeográficos da América do Sul. Baseado na diversidade de inversões cromossômicas e densidade populacional, o Chaco foi considerado por alguns autores como o “centro de origem” da espécie. Entretanto, trabalhos recentes, utilizando aloenzimas e DNA mitocondrial, apontaram para uma possível origem na Caatinga. Os objetivos deste trabalho foram delinear rotas de dispersão da espécie para explicar sua distribuição atual e possível distribuição durante o último período glacial, na América do Sul. Foram obtidas seqüências de 714 pb da COI do mtDNA de 132 indivíduos em 44 localidades, gerando 36 haplótipos. Foram calculados os índices de diversidade nucleotídica, o teste "AMOVA", testes de neutralidade, a "Mismatch Distribution”, "Baesyan Skyline Plot", "NCPA" e o sentido dos movimentos migratórios (Migrate N) a fim de determinar parte da história evolutiva da espécie. As diversidades nucleotídicas encontradas por Domínio foram de 0,0030 - Caatinga; 0,0019 - Mata Atlântica; 0,0020 - Cerrado; 0,0011 - Pampas e 0,0004 Chaco. A AMOVA mostrou que 68,33\% da variação é intra-populacional e que uma porção significativa da variação é devido a diferenças inter-regionais ( $\Phi c t=0,07124 \mathrm{p}=0,00196)$. Os testes de Neutralidade (D de Tajima = -2,4150, p = 0,0317 e Fs de Fu = -28,6719, p = 0,00001), a forma em estrela da rede e haplótipos, e a "Mismatch Distribution" confirmam um evento de expansão populacional estimado em aproximadamente 494.257,3 anos atrás, segundo modelo de Rogers e Harpending (1992). Entretanto, a "Baesyan Skiline Plot” demonstrou que esse movimento de expansão parece ser mais antigo, cerca de 550.000 - 650.000 anos atrás. A NCPA demonstrou que há fluxo gênico restrito com isolamento por distância, confirmado pelo teste de Mantel e alguma dispersão a longa distância em alguns dos clados analisados. O resultado do programa "Migrate N" indicou um padrão complexo migratório entre os domínios, porém um padrão norte/sul pôde ser verificado. A estruturação genética pode ser explicada devido à grande área de distribuição da espécie, gerando isolamento por distância e pela presença de barreiras geográficas e climáticas (entre o Cerrado e a Caatinga) e no estado do Rio de Janeiro e Espírito Santo (ao longo da Mata Atlântica) onde há pouco ou nenhum indivíduo da espécie. Os eventos de expansão ocorreram no Quaternário durante o período glacial conhecido como Ilinioian e suas subdivisões. A partir dos resultados deste trabalho foi possível traçar diversas rotas de migração possíveis entre os domínios utilizados, sendo que o movimento mais antigo partiu da Caatinga o que vai contra a hipótese de que o “Centro de Origem” seja o Chaco. 


\title{
The dispersion routes of Drosophila buzzatii in South America
}

\section{Santos, M. H.}

\begin{abstract}
The fruit-fly Drosophila buzzatii is a cactophilic species in association with cactus species distributed along the Phytogeographic Domains of Caatinga, Cerrado, Atlantic Forest, Pampas and Chaco. Based in the diversity of chromosomal inversion and populational density of the species, the Chaco Domain was considered the "Center of Origin" of the D. buzzatii. However, recent works, using allozymes and DNAmt, showed a possible origin of the $D$. buzzatii in the Caatinga. The objectives of this work were trace historical dispersion routes of $D$. buzzatii, current and ancient areas of distribution in the South America. We obtained DNA sequences in 132 samples in 44 localities with 714 bp length from the COI mtDNA gene, generating 36 haplotypes. The diversity indexes, AMOVA, neutrality tests, Mismatch Distribution, Baesyan Skyline Plot, NCPA and sense of migration movements was calculated, to describe part of the evolutionary history of the species. The nucleotide diversity was 0,0030 Caatinga, 0,0019 - Mata Atlântica, 0,0020 - Cerrado, 0,0011 - Pampas and 0,0004 - Chaco. The AMOVA results, grouped by Domain showed that $68,33 \%$ of the variation is intra-population and a significant portion of the variation is due to inter-regional differences $(\Phi c t=0,07124 \mathrm{p}=$ 0,00196). The Neutrality tests (Tajima's $\mathrm{D}=-2,4150, \mathrm{p}=0,0317$ and Fu's Fs $=-28,6719, \mathrm{p}=$ 0,00001), the star-shape of the haplotype network, and Mismatch Distribution showed population expansion signs, estimated in 494.257,3 ybp, according Rogers and Harpending model (1992). However, the BSP showed that the movement is ancient, estimated in 550.000 650.000 ybp. The NCPA showed restricted gene flow with isolation by distance, confirmed by the Mantel Test and some long distance dispersion. The results of the program Migrate $\mathrm{N}$ showed a complex pattern of migration between the domains, but a north/south pattern could be identified. The genetic structure can be explained to the widespread distribution of the species, that could generate isolation by distance and by the presence of geographic and climatic barriers (between Cerrado and Caatinga domains) and in the States of Rio de Janeiro and Espírito Santo (along the Atlantic Forest) when there is none or few individuals of the species D. buzzatii. The expansion movements occurred in the Quaternary Period during glaciations events in the Illinoian and their subdivisions, due to the decrease of the global moisture that generated favorable conditions to the expansion of the dry vegetation and associated species. Based on the results of this work it was possible to delineate many migration routes between the phytogeographic domains, and the more ancient movement started in the Caatinga and this result not support the hypothesis that Chaco was the "Center of Origin" from $D$. buzzatii.
\end{abstract}




\section{Introdução}

\subsection{Estrutura de populações e filogeografia}

A estrutura populacional é observada em praticamente todos os grupos de organismos. Inclusive a enguia européia Anguilla anguilla, considerada um exemplo clássico de população panmítica - porque todos os indivíduos migram para o mesmo local para se reproduzir - exibe certo grau de estrutura genética populacional (Wirth e Bernatchez 2001). Isso mostra que populações de uma mesma espécie, ao serem comparadas, em geral, apresentam algum tipo de diferença geográfica em relação a suas características genéticas e morfológicas (Mayr 1977). Esta estrutura pode ser verificada ao longo das distribuições geográfica e da variabilidade genética de uma espécie, e é determinada por diversos fatores geográficos, ecológicos e comportamentais, além das potencialidades genéticas de cada espécie e sua história biológica.

A estruturação populacional é resultado de processos evolutivos que atuam sobre a variabilidade presente nas populações, que surge através de mutações aleatórias, gerando novos alelos ou recombinações cromossômicas e fluxo gênico entre populações. Uma forma de descrever essa estruturação é utilizar uma abordagem filogeográfica. A filogeografia estuda os princípios e processos que regem a distribuição geográfica de linhagens genealógicas, no nível intra-específico (Avise 2000). Essa abordagem gera informações importantes sobre os processos evolutivos envolvidos na determinação dos padrões atuais de distribuição e diversificação entre populações e espécies. Os padrões atuais da distribuição geográfica da variação genética populacional de uma espécie é o resultado de eventos históricos, como vicariância e migração, ou recorrentes, como o fluxo gênico atual e variações ambientais recentes. A definição de tais eventos fornece informações para desvendar os processos evolutivos que podem ter levado populações a se diferenciar em espécies ao longo do tempo. Cada evento responsável pela diferenciação deve gerar uma marca genética e um padrão filogeográfico distinto (Templeton 1998; Avise 2000). Por exemplo, se as populações apresentarem um fluxo gênico espacialmente restrito, a estrutura será relacionada com populações geograficamente próximas, onde o aumento da distância entre as populações aumentará a diferenciação.

As inferências filogeográficas são fundamentadas na Teoria da Coalescência, a qual se baseia na identificação do processo genealógico de uma amostra de genes em 
uma população, capaz de identificar eventos que ocorreram com os genes desde o ancestral comum mais recente da amostra (Kingman 1982). Essa teoria é um tópico alvo nos estudos de populações, sendo reconhecida como premissa teórica em várias análises estatísticas no campo da filogeografia (Fu e Li 1999).

A grande diferença da abordagem filogeográfica para a abordagem puramente populacional reside no fato de que a filogeografia apresenta um enfoque na história da espécie, principalmente no passado biogeográfico (Knowles e Maddison 2002). Com esse enfoque é possível realizar estudos de processos micro e macro-evolutivos, além da descrição das distribuições geográficas das espécies, suas relações filogenéticas e distâncias genéticas entre linhagens evolutivas dos organismos, o que possibilita uma melhor compreensão da biogeografia regional e áreas de endemismo das espécies (Bermingham e Moritz 1998).

\subsection{0 “Cluster” Drosophila buzzatii e a espécie Drosophila buzzatii}

O “cluster” Drosophila buzzatii é composto por sete espécies nominais, $D$. buzzatii, D. serido, D. antonietae, D. seriema, D. gouveai, D. borborema e D. koepferae, endêmicas do continente americano, com exceção de $D$. buzzatii, que foi introduzida em outros continentes via uma de suas plantas hospedeiras, o cacto Opuntia fícus-indica, utilizado pelo homem para diversos fins (Barker et al. 1985). As espécies desse “cluster” são crípticas e cactófilas, ou seja, utilizam tecidos de cactos em decomposição durante o desenvolvimento larval (Pereira et al. 1983). Além disso, formas imaturas e adultas, também utilizam como fonte de alimentação leveduras presentes nos cactos em decomposição formando um modelo ecológico Drosophilaleveduras-cacto (Starmer et al. 1990). Esta restrição ecológica tem pelo menos duas conseqüências. A primeira é que a distribuição atual de suas populações é determinada pela ocorrência de cactáceas na América do Sul, o que inclui os Domínios do Chaco e Caatinga, e inúmeras populações isoladas em diferentes domínios fitogeográficos, as quais são restritas em tamanho. A segunda conseqüência é que os processos de diferenciação dentro do "cluster” podem ser relacionados com a expansão e retração da vegetação aberta na América do Sul, durante alterações paleoclimáticas, como aquelas promovidas por períodos glaciais (Sene et al. 1982).

As relações filogenéticas para o "cluster” são definidas, principalmente, com base em inversões cromossômicas (Ruiz e Wasserman 1993), seqüências de DNA 
mitocondrial e nuclear (Manfrin et al. 2001; Franco et al. 2006; Franco et al. 2010). Estes dados sugerem que este “cluster” é um grupo monofilético, formado por duas linhagens filéticas principais. Uma compreende a espécie D. buzzatii e a segunda as outras seis espécies que compõe o “cluster”, sendo esta linhagem denominada $D$. serido “sibling set” (Tidon-Sklorz e Sene 2001; Manfrin e Sene 2006) (Figura 1). Segundo datações moleculares a divergência das espécies do “cluster” D. buzzatii ocorreu no Período Terciário, desta maneira, a separação do clado composto por $D$. buzzatii e $D$. koepferae teria ocorrido há cerca de 6-12 milhões de anos, enquanto que a divergência do clado composto por $D$. antonietae (Clado D) do clado formado pelas espécies $D$. seriema, $D$. serido, $D$. borborema e $D$. gouveai (Clado AB), teria ocorrido entre 3-6 milhões de anos atrás (Figura 6c; Manfrin et al. 2001). Porém, trabalhos mais recentes utilizando o gene mitocondrial CO-I tem sugerido que o tempo para o ancestral comum mais recente do clado AB seria de aproximadamente 843 mil anos (HPD1 95\%: 0,343 até 1,413), incluindo essa divergência no período do Pleistoceno (Franco 2010).

Com relação à distribuição geográfica, D. buzzatii tem uma ampla distribuição, ocorrendo em toda a área conhecida de ocorrência do “cluster”, inclusive em simpatria com as demais espécies. As outras espécies do "cluster” têm distribuições geográficas restritas e menores densidades populacionais quando comparadas a $D$. buzzatii (Manfrin e Sene 2006).

As análises filogeográficas desenvolvidas para espécies deste grupo (De Brito et al. 2002, 2002; Morales 2005; Franco 2009; Moraes et al. 2009) têm identificado, como principal evento que explica a distribuição atual das populações, a expansão de área de ocorrência, muito provavelmente como conseqüência da associação com as cactáceas (Manfrin e Sene 2006).

Baimai, Sene e Pereira (1983) analisaram cromossomos metafásicos comparando populações brasileiras de $D$. buzzatii e populações argentinas, verificando que cariotipicamente as populações são idênticas. Resultados semelhantes foram obtidos com dados aloenzimáticos e do gene alfa-esterase 5, os quais não mostraram diferenciação entre as populações brasileiras e argentinas e entre as populações argentinas e australianas (Piccinali et al. 2007). Entretanto, no trabalho de (Barker et al. 1985), duas exceções foram apontadas. A primeira foi a descoberta de uma população no nordeste do Brasil (na região de Irecê, Bahia) monomórfica para três loci 
aloenzimáticos, polimórficos na maioria das outras populações analisadas, entretanto polimórfica para o lócus $M d h$ com dois alelos em freqüências intermediárias. A segunda consiste no fato de que uma população do Sul do Brasil (na região de Tramandaí, na costa do Rio Grande do Sul) apresentou polimorfismo em três loci (Hk-3, $\beta$-Hbdh e $X d h)$, sendo estes monomórficos em outras populações e esta localidade apresentou a maior heterozigosidade dentre todos os alelos. Análises de inversões cromossômicas mostraram que as populações do Domínio do Chaco possuíam 16 inversões polimórficas (Ruiz et al. 1984); destas, duas estão presentes nas populações do Sul do Brasil e nenhuma foi encontrada no nordeste brasileiro (Barker et al. 1985; Figueiredo e Sene 1992). As informações a cerca da variabilidade de inversões cromossômicas no Chaco e alta densidade populacional da espécie $D$. buzzatii nesta região foram a base para a formulação da hipótese de que a espécie $D$. buzzatii tem como centro de origem o Chaco e que, posteriormente, expandiu sua área de ocorrência até o nordeste do Brasil (Carson e Wasserman 1965; Figueiredo e Sene 1992).

Partindo desta hipótese, duas possibilidades foram propostas para explicar a dispersão de $D$. buzzatii pelo território brasileiro. Na primeira, a dispersão seria passiva e a colonização do Brasil teria ocorrido recentemente, associada à planta hospedeira, levada pelo homem (Sene et al. 1988). A hipótese alternativa propõe um processo de expansão natural, seguindo a expansão dos cactos favorecida por alterações climáticas durante o Quaternário na América do Sul (Barker et al. 1985).

Uma análise filogeográfica utilizando seqüências do gene mitocondrial COI, analisando uma amostra pequena e, basicamente, de populações da área central de distribuição da espécie (De Brito, Manfrin e Sene 2002), mostrou que a espécie $D$. buzzatii apresenta baixa diversidade nucleotídica. Entretanto, as populações brasileiras apresentaram, em média, 50\% mais polimorfismo do que as populações argentinas (De Brito, Manfrin e Sene 2002). As populações do Chaco argentino apresentaram a menor diversidade nucleotídica, seguidas das populações do sul do Brasil e a região Nordeste apresentou-se duas vezes mais polimórfica do que a região sul. A análise filogeográfica sugeriu fluxo gênico restrito pela distância e isolamento por distância ou vicariância, separando as populações do nordeste do Brasil. 


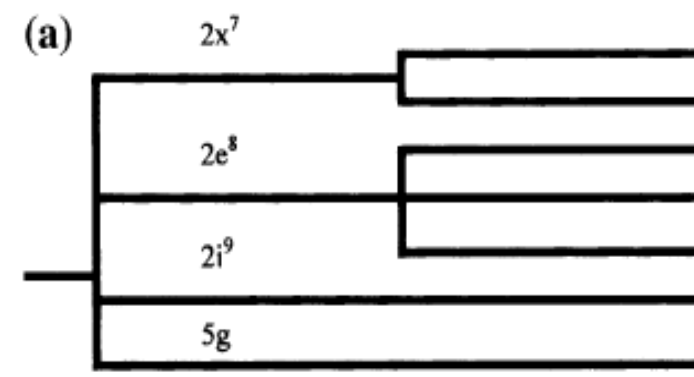

\section{D. serido}

D.antonietae

D.borborema

D.seriema

D.gouveai

D.koepferae

D.buzzatii

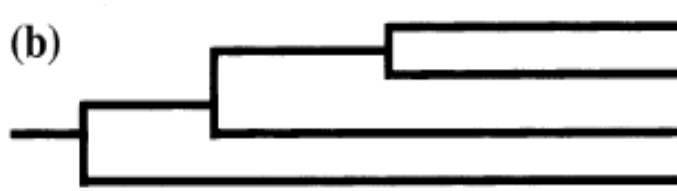

D. serido

D.borborema

D.koepferae

D.buzzatii

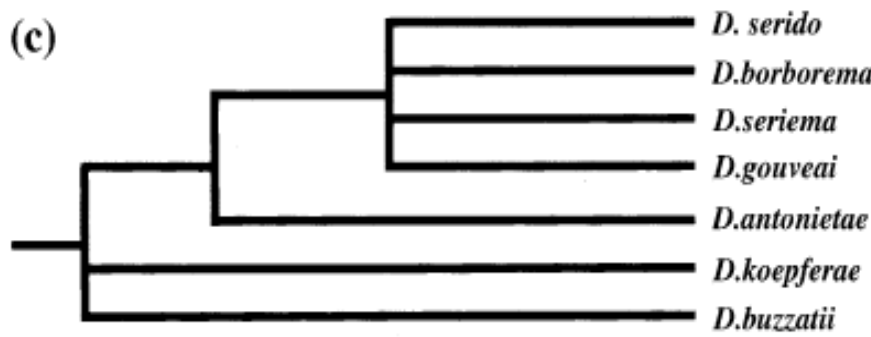

(d)

D.buzzati

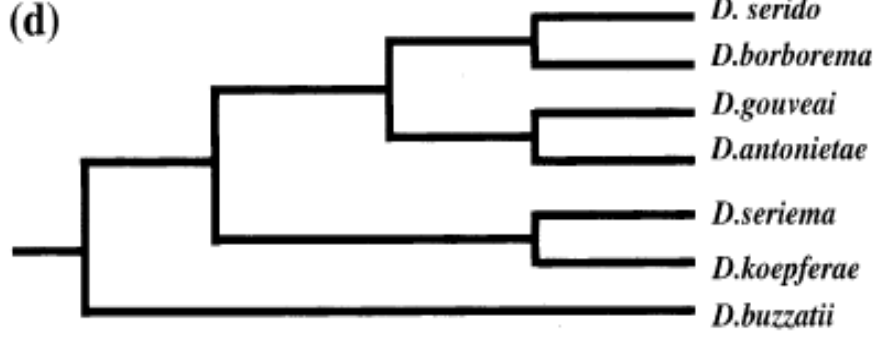

(e)

uzzati

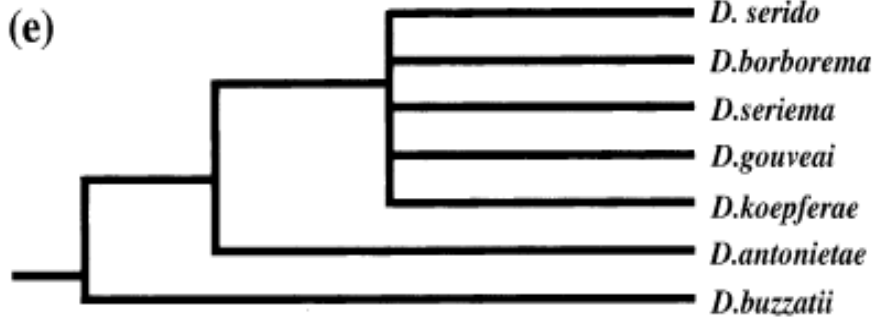

Figura 1. Relações filogenéticas das espécies do "cluster" Drosophila buzzatii baseada em diversos marcadores e modificado de Manfrin et al. (2006). Em (a) hipótese baseada em fixação de inversões cromossômicas (Ruiz et al. 2000), (b) hipótese baseada nas sequências do gene Xdh (RodriguezTrelles, Alarcon e Fontdevila 2000), (c) hipótese baseada em sequencias do gene mitocondrial COI (Manfrin, De Brito e Sene 2001), (d) hipótese baseada em distâncias morfológicas de 17 parâmetros de asas (Moraes et al. 2004), (e) hipótese baseada em amostras de DNA satélite (Kuhn 2003).

De fato, os dados de diversidade nucleotídica e de haplótipos mais divergentes, ocorrendo nas populações do nordeste, entram em conflito com a hipótese de expansão recente para o nordeste do Brasil, via populações do Chaco argentino. Os dados aloenzimáticos podem ser interpretados como uma antiga fragmentação entre as 
populações brasileiras de $D$. buzzatii, permitindo uma diferenciação e baixa variação das inversões cromossômicas (Barker et al. 1985; Figueiredo e Sene 1992). Os dados moleculares mostram ainda que a expansão da região Sudeste brasileira ocorreu há pelo menos 100.000 anos, indicando um evento pré-holocênico, antes da colonização humana (De Brito, Manfrin e Sene 2002). Portanto, esses resultados não apoiam a hipótese de dispersão passiva, mas sim de uma dispersão ativa da espécie $D$. buzzatii. Os altos níveis de polimorfismo do DNA mitocondrial (De Brito et al. 2002), encontrados na região nordeste do Brasil, assim como os alelos privados (Barker et al. 1985), sugerem que a hipótese do Chaco argentino como centro de origem deve ser revisada. Trabalhos de associação entre $D$. buzzatii e suas plantas hospedeiras tem demonstrado que há grande variação na viabilidade, tempo de desenvolvimento e tamanho do tórax de $D$. buzzatii dependendo do cacto hospedeiro e de qual inversão cromossômica no cromossomo dois a espécie carrega (Iriarte e Hasson 2000). O resultado do trabalho de Iriarte e Hasson (2000) demonstrou que indivíduos de $D$. buzzatii utilizando meio de cultura contendo o cacto Trichocereus terschekii (uma espécie de cacto colunar muito comum na Argentina) e o arranjo $2_{\text {st }}$ apresentaram uma viabilidade significativamente maior do que nos outros tratamentos, já os arranjos cromossômicos $2_{\mathrm{jq}}{ }^{7}$ aumentaram a viabilidade nos meios de cultura contendo Opuntia fícus-indica e Opuntia vulgaris, concluindo que a interação cacto/cariótipo é dependente do tipo de recurso alimentar que a espécie utiliza (Iriarte e Hasson 2000). Já o trabalho de (Fanara e Hasson 2001) demonstrou que D. buzzatii ovoposita mais em cactos do gênero Opuntia, entretanto a exploração de outras espécies de cactos ocorre, mas na natureza, $D$. buzzatii emerge principalmente da espécie $O$. sulphurea. Portanto, como características importantes a sobrevivência de $D$. buzzatii como a viabilidade e taxa de ovoposição são dependentes em parte, dos arranjos cromossômicos presentes nas populações (Iriarte e Hasson 2000; Fanara e Hasson 2001), é plausível supor que tenha ocorrido seleção natural forte nas populações de $D$. buzzatii no domínio do Chaco e que esse processo de seleção pode ter favorecido o aumento da freqüência de inversões cromossômicas favoráveis a sobrevivência da espécie neste domínio fitogeográfico.

Uma análise comparativa entre a história evolutiva proposta para as espécies do $D$. serido "sibling set" e $D$. buzzatii mostra diferenças marcantes, ou seja, espécies que são proximamente relacionadas, quando submetidas aos mesmos ambientes, reagem de forma distinta em um senso evolutivo. Isto é evidente quando se comparam a 
distribuição da variação entre populações da espécie $D$. buzzatii e as outras espécies do “cluster”. A espécie $D$. buzzatii tem uma distribuição geográfica ampla e é encontrada em simpatria com praticamente todas as espécies do D. serido "sibling set". Apesar disto, para esta espécie existe diferenciação significativa apenas para alguns marcadores, como a forma e tamanho, de asa e edeago, como sugerem as análises morfométrias, sendo que este resultado também sugere uma divisão das populações do domínio da Caatinga em um grupo em relação aos outros domínios formando outro grupo (Santos 2009; Santos e Manfrin 2010).

A espécie $D$. buzzatii é considerada a mais proximamente relacionada ao grupo externo dentro do “cluster” D. buzzatii (Manfrin, DeBrito e Sene 2001). Se sua distribuição atual é tão antiga quanto à das outras espécies do “cluster” (Manfrin e Sene 2006), a espécie $D$. buzzatii também deve ter sido influenciada pelos eventos de fragmentação históricos sugeridos para a outra linhagem evolutiva, como o $D$. serido “sibling set” do “cluster” D. buzzatii (Manfrin, DeBrito e Sene 2001), que apresenta seis espécies distintas com populações politípicas, porém, reagindo a estes eventos de uma forma distinta. Isso classifica $D$. buzzatii como uma espécie com forte coesão genômica, conforme hipótese elaborada por Carson e Wasserman (1965).

\subsection{Flutuações climáticas e rotas de dispersão da vegetação na América do}

\section{Sul}

Existem indícios de que o planeta Terra passou por flutuações climáticas que tornaram o clima global mais frio e seco, formando os chamados períodos glaciais. Santana-Neto et al. (2005) sugerem que na era Paleozóica ocorreram dois eventos de glaciação expressivos, um no início do Cambriano (há 570 milhões de anos) e outro no final do Permiano (há 250 milhões de anos). Porém, no Plioceno superior (entre 2,6 e 1,8 milhões de anos) e no Quaternário (há 1,8 milhões de anos) houve um aumento na frequencia desses períodos de resfriamento do planeta. Foram registrados pelo menos 16 eventos de glaciação durante o Pleistoceno, no período Quaternário, sendo que a média de duração desses eventos foi de 100 mil anos, intercalados por períodos de aumento da temperatura e umidade (interglaciações) (Salgado-Labouriau 1994; Suguio et al. 2005).

Os períodos glaciais foram notavelmente mais severos no hemisfério norte e em algumas áreas no extremo sul do hemisfério sul como a Patagônia argentina (Zeisset 
e Beebee 2008), por exemplo, pois ocorreu avanço das geleiras sobre os continentes, ocasionando a extinção de populações e espécies não adaptadas a essa nova condição. As populações das espécies sobreviventes ficaram restritas em locais de condições climáticas mais amenas, denominados refúgios. Por esse motivo, estudos filogeográficos no hemisfério norte, geralmente encontram padrões de isolamento geográfico durante os períodos glaciais e expansão populacional nos períodos interglaciais (Hewitt 2000; Alexandrino et al. 2002; Kotlik et al. 2004). Porém, no hemisfério sul não ocorreu aumento significativo das geleiras, com exceção de algumas partes da Patagônia argentina (Zeisset e Beebee 2008), mas alterações da temperatura e umidade podem ter causado alterações significativas nos ambientes neotropicais durante esses ciclos (Ab’Saber 1977; Clapperton 1993; Hewitt 2000; Ledru et al. 2005).

Segundo Haffer (1969) e Vanzolini e Williams (1970), durante os períodos glaciais, o clima no hemisfério sul tornou-se frio e seco e essa mudança favoreceu a expansão geográfica da flora adaptada (vegetação xerófita) e, por conseqüência, da fauna associada. Domínios fitogeográficos como o Cerrado e a Caatinga, substituíram áreas de vegetação mesófila, como a Amazônia e a Floresta Atlântica, que ficaram restritas a locais de maior umidade, os refúgios do Quaternário (Haffer 1969; Vanzolini e Williams 1970). Porém, durante os períodos interglaciais, de clima quente e úmido, esse cenário se inverteu (Ab’Saber 1977; Pennington et al. 2000). Uma série de estudos geomorfológicos (Ab’Saber 1977; Wang et al. 2004), palinológicos (Behling e Lichte 1997; Behling 1998; De Oliveira et al. 1999; 2002; Ledru et al. 2005; Ledru et al. 2006; Ledru 1991), com paleodunas (De Oliveira et al. 1999), espeleológicos (Auler e Smart 2001; Auler et al. 2004; Wang et al. 2004), de paleomodelagens (Mayle et al. 2004; Carnaval e Moritz 2008; Carnaval et al. 2009; Thomé et al. 2010; Werneck et al. 2010), fito e filogeográficos (Pennington et al. 2000; Taylor e Zappi 2004; Wüster et al. 2005; Carnaval e Bates 2007; Quijada-Mascareñas et al. 2007; Caetano et al. 2008; Moraes et al. 2009), apóiam a hipótese de flutuações cíclicas na temperatura e umidade na América do Sul, afetando a cobertura vegetal no Continente Americano.

Antigos solos pedregosos na atual área de distribuição do domínio do Cerrado, hoje soterrados, poderiam ter sido ocupados por espécies vegetais de Cerrado naturalmente degradadas ou da Caatinga (Ab’Saber 1977, 2003). Outras evidências da expansão do domínio da Caatinga são: minienclaves de cactáceas ao longo do domínio do Cerrado, no Brasil central (Ab'Sáber 2003), enclaves de vegetação xerófitas na 
região de Macaé-Cabo Frio/RJ e corredores de cerrado ligando o centro-oeste do Brasil ao norte da Floresta Amazônica (Ab’Saber 2003).

Alguns autores (Prado e Gibbs, 1993; Prado 2000, Pennington et al. 2000), estudando a distribuição atual de espécies vegetais das Florestas Tropicais Sazonalmente Secas (FTSS), que tem como característica espécies vegetais semidecíduas (que perdem as folhas durante períodos de seca), sugerem que essas formações vegetais foram mais difundidas nos períodos frios e secos do Pleistoceno. Essas informações levaram os autores (Prado e Gibbs 1993) a proporem a existência do arco Pleistocênico, relíquias formadas por vicariância de uma formação florestal pleistocênica de grandes dimensões que cobriam a América do Sul.

No Brasil existem dois grandes núcleos de FTSS: o domínio da Caatinga e regiões da Bacia do Paraná-Paraguai, conhecido como Núcleo Missiones (Morrone 2006; Prado e Gibbs, 1993; Prado, 2000). Prado e Gibbs (1993) propõem a conexão desses núcleos durante os períodos frios/secos do Pleistoceno, por dois caminhos principais, a rota norte e rota sul. A rota norte ligou o domínio da Caatinga ao estado de Goiás, atravessado por uma estreita faixa, áreas de Cerrado atuais, seguindo os vales do Rio Grande, até a região do Distrito Federal, desviando ao norte até a região da Ilha do Bananal, em Tocantins, e ao sul até o Pantanal mato-grossense (Prado e Gibbs, 1993; Prado, 2000). A rota sul estendeu-se pelos vales do Rio São Francisco e Jequitinhonha, e ao sul ao longo do Rio das Velhas, até a região da cidade de Belo Horizonte e seguindo a leste até o estado do Rio de Janeiro (Prado e Gibbs, 1993; Prado, 2000) (Apêndice 2). Rotas similares ligando o domínio da Caatinga e o centro-oeste do Brasil e o estado do Rio de Janeiro também foram propostas por Ab’Saber $(1977,2003)$.

A hipótese de rotas históricas de vegetação adaptada a climas secos é apoiada por trabalhos de fitogeografia de cactos neotropicais, por exemplo, Discocactus heptacanthus e D. bahiensis ocorrem em áreas da Caatinga, no nordeste brasileiro, e em campos rupestres no sudeste do Brasil (Taylor e Zappi, 2004). A distribuição de gêneros de cactos como Pereskia, Praecereus, Hilocereus, Pilosocereus, Cereus, entre outros, também apóiam as rotas históricas de migração da vegetação adaptada a climas secos (Taylor e Zappi, 2004). 


\subsection{Domínios fitogeográficos}

Muitos trabalhos utilizam o termo "bioma” como sinônimo de “domínios fitogeográficos”, entretanto isso é incorreto (Coutinho 2006). O termo "Bioma” referese a uma área que apresenta homogeneidade fisionômica sem levar em consideração a composição florística, já o termo “domínio fitogeográfico” implica em heterogeneidade fisionômica e leva em consideração a composição florística como componente importante para a sua distinção (Fiaschi e Pirani 2009). Baseado nessas informações foi adotado a divisão em cinco domínios fitogeográficos propostos por (Fiaschi e Pirani 2009): Caatinga, Cerrado, Floresta Atlântica (a qual inclui as Florestas de Araucárias), Pampas/Campos Sulinos e o domínio do Chaco (Figura 2).

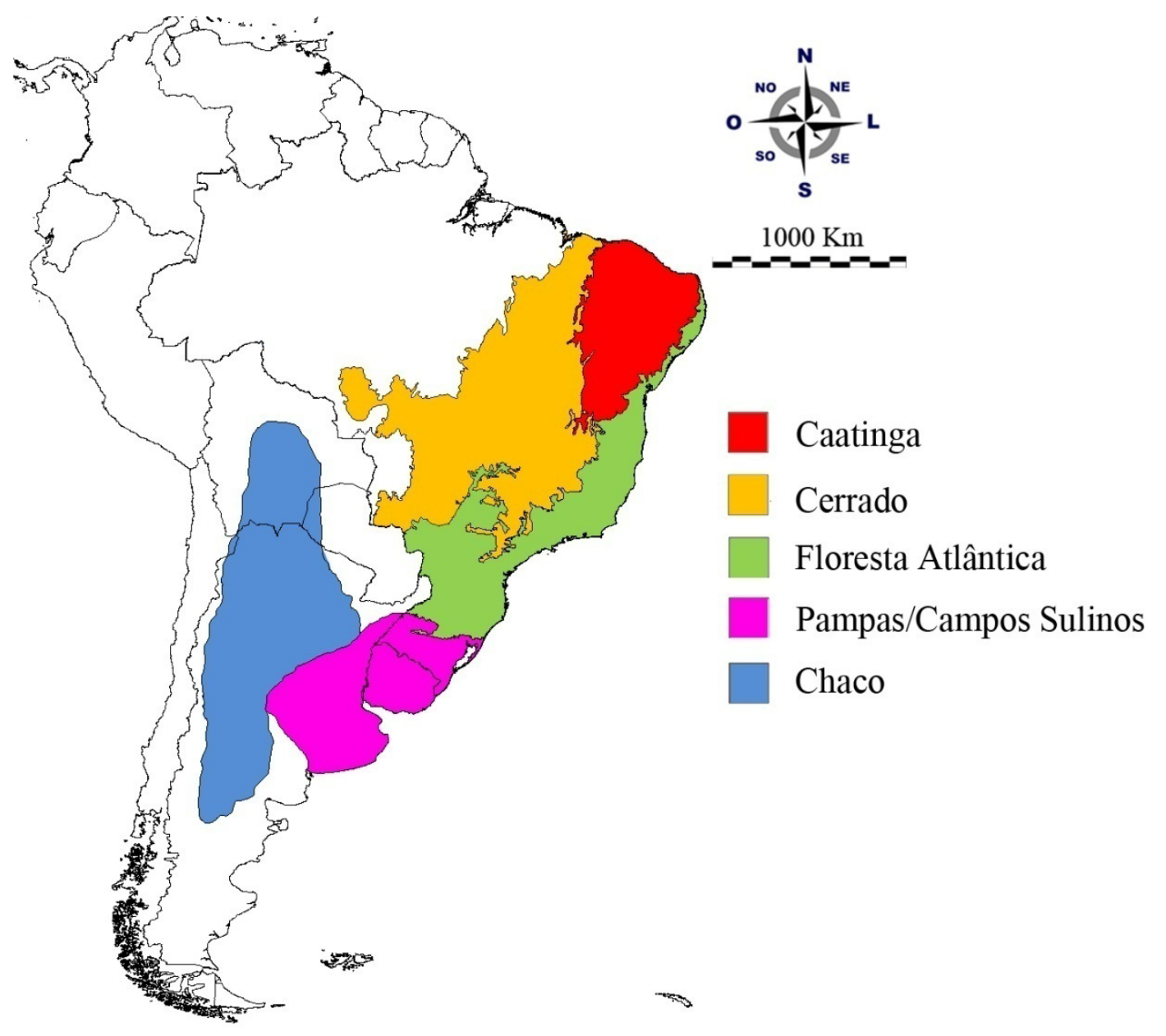

Figura 2. Mapa representando os domínios fitogeográficos utilizados neste trabalho, os domínos no Brasil são correspondentes à divisão proposta pelo Instituto Brasileiro de Geografia e Estatística. 


\subsubsection{Cerrado}

O domínio do Cerrado originalmente ocupa uma área de aproximadamente 2 milhões de $\mathrm{km}^{2}$ no Planalto Central do Brasil, o qual se estende a oeste até a Bolívia, sul do Paraguai e leste até a Caatinga. O cerrado possui ainda pedaços de vegetação no interior da Amazônia, Floresta Atlântica e Caatinga (Prance 1996; Daly e Mitchell 2000; Fiaschi e Pirani 2009). A maior parte da vegetação do cerrado é constituída por savanas e solo rico em gramíneas, mas pobre em nutrientes, apresentando altas concentrações de alumínio (Eiten 1972; Ratter et al. 1997; 2006; Fiaschi e Pirani 2009).

O cerrado apresenta grande riqueza de plantas vasculares variando de 6429 10500 espécies (Mendonça et al. 1998; Ratter et al. 2006), sendo que 35\% da vegetação arbustiva e $70 \%$ da vegetação arbórea é endêmica desse domínio fitogeográfico (Pennington et al. 2006; Ratter et al. 2006), enquanto que a maioria das espécies não endêmicas de plantas estão associadas com o domínio da Floresta Atlântica (Méio et al. 2003; Ratter et al. 2006). A maioria das espécies vive em uma altitude acima de 9001000 metros em formações rochosas conhecidas como campos rupestres (Giulietti e Pirani 1988; Harley e Stannard 1995; Alves et al. 2007).

No Cerrado, extensos planaltos de terreno sedimentar se formaram durante todo o terciário, em regiões com vegetação aberta sob climas secos (Zanella 2010). Gottsberger e Silberbauer-Gottsberger (2006) assumiram que o desenvolvimento inicial do cerrado se deu entre 28 e 25 m.a.a., no Oligoceno superior. Esse parece ter sido o momento de expansão de uma biota representativa de Cerrado para uma configuração próxima à atual, e a origem de seus vários componentes pode ser mais antiga (Zanella 2010).

Poucos estudos sugerem eventos de diversificação recentes (3-4.7 milhões de anos) em altas altitudes em clados vegetais que incluem Viguiera (Asteraceae), Microlicieae (Melastomataceae) e Minaria (Apocynaceae) (Schilling et al. 2000; Fritsch et al. 2004; Rapini et al. 2007, respectivamente). Eventos de expansão populacional mais recente foram relatados para Drosophila gouveai (450.000 anos atrás) (Moraes et al. 2009). Segundo Moraes et al. (2009), baseado em resultados de diversidade nucleotídica e análises filogeográficas, a espécie $D$. gouveae apresentou um movimento de expansão populacional no sentido norte/sul dividindo-se em dois grupos que acompanharam a expansão das suas plantas hospedeiras em topos de morros. Um desses 
grupos, chamado de subclado G1 passou por um processo de expansão das populações do norte/leste para o sul pelos topos das montanhas a leste do vale do Rio Paraná enquanto que o outro grupo, o subclado G2 passou por um processo de expansão populacional independente no sul do centro do Brasil, utilizando os topos a oeste do vale do Rio Paraná (Moraes et al. 2009).

\subsubsection{Floresta Atlântica}

A Floresta Atlântica originalmente ocupava uma área de aproximadamente 1,5 milhões de quilômetros quadrados do Rio Grande do Norte ao Rio Grande do Sul ao longo da costa brasileira (Fiaschi e Pirani 2009). A largura da floresta é muito variável, estendendo-se, por exemplo, em algumas áreas do sudeste do Brazil até o leste do Paraguai e na província de Missiones na Argentina (Galindo-Leal e Câmara 2003; Oliveira-Filho et al. 2006). A Floresta Atlântica é separada da Amazônia por uma faixa praticamente contínua de vegetação aberta que se estende no sentido Nordeste-Sudoeste (Prado e Gibbs 1993; Prado 2000; da Silva et al. 2004), embora existam evidências de conexões entre elas (Mori et al. 1981; Oliveira-Filho e Ratter 1995; Costa 2003). O domínio da Floresta Atlântica é caracterizado em sua maioria por floresta tropical sempre verde, mas formações do tipo Floresta Tropical Sazonalmente Seca (FTSS) (Oliveira-Filho et al. 2006) e Floresta Subtropical, incluindo a Floresta de Araucária (Cabrera e Willink 1973; Fiaschi e Pirani 2009) são usualmente consideradas partes desse domínio (Oliveira-Filho e Fontes 2000; Morrone 2006). As FTSS possuem porte, área basal e produtividade menor que as florestas tropicais úmidas, sendo compostas por vegetação decídua (Zanella 2010). Diferentemente do Cerrado, os solos das FTSS são férteis, existindo um gradiente de formações vegetacionais, incluindo florestas de porte grande nos locais mais úmidos e formações arbustivas com abundância de cactos nos locais mais secos, resultando em uma variedade de nomes locais (Zanella 2010). Baseado na distribuição atual das espécies encontradas nas FTSS há uma maior proximidade entre os núcleos da Caatinga e de Missiones, via sudeste do Brasil (Zanella 2010). Entretanto, Prado (2000) ressaltou a possibilidade de uma via alternativa de contato pelo Cerrado que segue do oeste da Bahia até os afloramentos de calcáreo do Distrito Federal, depois a leste de Goiânia, no Mato Grosso e áreas de Xavantina/Cachimbo, Ilha do Bananal até o norte de Cuiabá e elevações calcáreas de Corumbá e Urucum no Mato Grosso do Sul, próximos das florestas Chiquitanas na Bolívia (Zanella 2010). 
A Floresta Atlântica apresenta outras fisionomias como mangues e arbustos de restinga amplamente distribuídos nas áreas arenosas ao nível do mar (Scarano 2002) e porções em altas altitudes de afloramentos rochosos com gramíneas, usualmente acima dos $2000 \mathrm{~m}$ ao longo da Serra do Mar e da Mantiqueira (Safford 1999, 2007). A vegetação Montana apresenta uma flora altamente endêmica (mais de 20\%) apresentando fortes conexões florísticas com outras áreas montanas da América do Sul como os Andes (Safford 2007) e campos rupestres da Cadeia do Espinhaço (Giulietti e Pirani 1988; Di Maio 1996; Safford 1999; Calió et al. 2008).

Múltiplos centros de endemismo foram propostos para grupos de organismos na Floresta Atlântica (Prance 1982; Cracraft 1985; Soderstrom et al. 1988; Costa et al. 2000; da Silva et al. 2004; Melo Santos et al. 2007), porém o número desses é variável dependendo do organismo considerado (Fiaschi e Pirani 2009). Deste modo, embora muitos estudos apontem para a existência de dois blocos, separados no sentido norte/sul (Cracraft 1985; Soderstrom et al. 1988), estudos em escalas mais finas utilizando organismos com baixa vagilidade sugerem áreas menores a mais numerosas (Pinto-daRocha et al. 2005). Tomados os devidos cuidados quanto ao organismo estudado e o método utilizado, muitos estudos concordam que há uma separação histórica entre a parte norte e sul do domínio, sendo que esse limite coincide com vale do Rio Doce (norte do estado do Espírito Santo) (Cracraft e Prum 1988; Amorim e Pires 1996; Costa 2003; da Silva et al.2004; Pinto-da-Rocha et al. 2005; Perret et al. 2006).

Considerando essa divisão, a Floresta Atlântica do Norte abrange do Rio Grande do Norte ( $5^{\circ} \mathrm{S}$ ) ao extremo norte do Espírito Santo (19 S) e compreende uma estreita faixa de vegetação com o domínio da Caatinga a oeste na porção norte (Thomas e Barbosa 2008), como também áreas no interior conhecidas como "brejos nordestinos" (Rodal e Sales 2008) e a floresta da Chapada Diamantina (Funch et al. 2008).

A parte sul do domínio (Floresta Atlântica Sul) abrange do Espírito Santo (19 S) até o extremo sul de Santa Catarina ( $\left.29^{\circ} \mathrm{S}\right)$ e inclui grandes extensões de FTSS na sua porção oeste no extremo sul do Brasil, leste do Paraguai, e Missiones na Argentina (Oliveira-Filho e Fontes 2000; Oliveira-Filho et al. 2006), e a Floresta de Araucária (Morrone 2006). A FTSS da bacia Paranaense e o núcleo de Missiones, atualmente, são considerados unidades fitogeográficas distintas (Prado 2000; Pennington et al. 2006). 


\subsubsection{Caatinga}

O domínio da Caatinga encontra-se no nordeste do Brasil e é a maior área contínua de FTSS da América do Sul, originalmente cobrindo uma área de aproximadamente $850.000 \mathrm{~km}^{2}$ (de Queiroz 2006). A vegetação varia de áreas abertas com arbustos espinhosos a florestas secas baixas, condicionada pela prevalência do clima semi-árido, com alto potencial de evapotranspiração (1.500-2.000 mm/ano) e baixa precipitação (300-1000 mm/ano) concentrada durante um curto período de 3-5 meses (Sampaio 1995; de Queiroz 2006). A diversidade florística da Caatinga é relativamente pouco conhecida e estudada (Sampaio 1995), especialmente quando comparada com a Floresta Atlântica e Cerrado (Castro et al. 1999; Myers et al. 2000; Fiaschi e Pirani 2009), entretanto, $46 \%$ das espécies vegetais são endêmicas (Pennington et al. 2006).

Segundo Gottsberger e Silberbauer-Gottsberger (2006), a formação da Caatinga foi concomitante ao Cerrado, entretanto, a Caatinga em áreas de maior aridez que o Cerrado, em parte devido ao soerguimento dos Andes.

A composição florística da Caatinga apresenta forte ligação com outros núcleos de FTSS da América do Sul, como Missiones, Piedmont, da Costa Caribenha da Colômbia e Venezuela, e dos vales secos inter-Andinos, mas não com o domínio do Chaco (Prado e Gibbs 1993; Pennington et al. 2000; Prado 2000; Pennington et al. 2006). O reconhecimento recente de que as FTSS representam unidades biogeográficas em forma de arquipélagos (Prado 2000) estimularam o interesse no descobrimento dos processos históricos que moldaram a distribuição atual dos táxons centrais das FTSS (Pennington et al. 2000; 2004; Lavin 2006; Ritz et al. 2007). Poucos estudos têm focado especificamente na Caatinga (Pennington et al. 2006).

Devido à distribuição geográfica conhecida de 274 espécies vegetais da Caatinga, a flora deste domínio pode ser dividida em dois blocos distintos (Fiaschi e Pirani 2009). Um desses blocos está associado a solos derivados de bases cristalinas e apontam para uma ligação florística da Caatinga com áreas remanescentes das FTSS (Prado 2000). Já o segundo bloco corresponde a plantas que crescem em sedimentos arenosos ao longo do domínio e que parecem ser a maioria das espécies endêmicas de Leguminosas encontradas na Caatinga (Fiaschi e Pirani 2009). 
O desenvolvimento histórico desse cenário foi proposto como o resultado de um amplo processo de pediplanação durante o Quaternário recente que descobriu as rochas cristalinas do Pré-cambriano da região (Fiaschi e Pirani 2009). De acordo com esta hipótese, as recentes e contínuas superfícies sedimentares se tornaram ressecadas, conduzindo a diferenciação alopátrica dos táxons vegetais. As áreas expostas derivadas das formações cristalinas são ocupadas por elementos típicos da flora das FTSS (de Queiroz 2006), que se desenvolveram durante o Mioceno-Plioceno (Pennington e Dick 2004; Saslis-Lagoudakis et al. 2008) e devem ter migrado tardiamente para a Caatinga.

\subsubsection{Campos Sulinos/Pampas}

Grandes áreas do extremo sul do Brasil são cobertas por gramíneas em formações chamadas campos, que são pastagens naturais (Overbeck et al. 2006). É possível distinguir os campos do Planalto Meridional, o qual ocorre no domínio da Floresta Atlântica e vai do Paraná até o norte do estado do Rio Grande do Sul dos contínuos pampas ou campos da Campanha Gaúcha, os quais cobrem grandes áreas no estado do Rio Grande do Sul e áreas vizinhas como o Uruguai e Argentina (Província do Pampa, segundo Morrone (2006). Essa distribuição desigual dos campos do planalto é uma consequência da sua dinâmica com a Floresta de Araucária, a qual tende a avançar sobre os campos (Klein 1960; Behling et al. 2004; Overbeck et al. 2007).

Baseados nas diferenças na composição florística, alguns autores separam a vegetação de gramíneas no extremo sul do Brasil e Uruguai (norte do Rio da Prata) dos pampas Argentinos (Soriano 1992). A palavra "pampa" tem origem Quechua e significa "região plana", neste sentido, ela inclui todas as áreas baixas e planas da bacia do Rio da Prata até o norte da Serra Geral (Fiaschi e Pirani 2009). Neste trabalho o termo Pampa foi utilizado em um sentido amplo, concordando com a Província do Pampa proposta por Morrone (2006) e utilizada por Fiaschi e Pirani (2009), abrangendo os campos sulinos e também os pampas propriamente ditos.

A diversidade vegetal dos Pampas foi estimada entre 3.000 e 4.000 espécies (Overbeck et al. 2007), e alguns estudos apontam que a região pode ser a mais rica em espécies de gramíneas no mundo (Overbeck et al. 2006). O domínio praticamente é composto por gramíneas, mas também apresentam arbustos de várias famílias (Fiaschi e Pirani 2009). A flora do domínio dos Pampas em geral apresenta conexões com outras formações vegetais de áreas abertas da América do Sul e muitos elementos da flora 
herbácea do domínio do Cerrado têm seus limites de distribuição nos Pampas (Boechat e Longhi-Wagner 2000), onde muitos dos elementos da flora temperada/subtropical são razoavelmente comuns (Fiaschi e Pirani 2009). A aparente natureza transicional da flora dos Pampas é mais evidente no estado do Rio Grande do Sul, onde os campos de planalto são substituídos pelos pampas na latitude 30 S (Smith 1962; Burkart 1975; Waechter 2002; Ritter e Waechter 2004; Overbeck et al. 2007).

Muitos exemplos de táxons derivados dos Andes são conhecidos no sul do Brasil (Rambo 1956; Smith 1962). Um bom exemplo dessa conexão é a presença da espécie Gunnera manicata (Gunneraceae) nas colinas úmidas e pântanos nas áreas de planalto do extremo oriental de Santa Catarina e Rio Grande do Sul (Fiaschi e Pirani 2009). Dispersão de gêneros tipicamente andinos pela Argentina para o sul do Brasil (Klein 1960; Leite 2002) e das pastagens de bacia do Paraná para os Andes (Katinas e Crisci 2008) foram reportadas. Os padrões de disjunção resultantes são apoiados não somente por similaridade das condições climáticas, mas também por conexões do Quaternário que poderiam ter tido lugar durante os períodos interglaciais mais úmidos (Ortiz-Jaureguizar e Cladera 2006; Fiaschi e Pirani 2009).

\subsubsection{Chaco}

O Domínio do Chaco apresenta vegetação semi-árida que ocorre na transição entre as regiões tropical e temperada (Morello e Adámoli 1967). O clima do Chaco é sazonal, com verões extremamente quentes e invernos severos, com a ocorrência de geadas. A precipitação média varia entre $500 \mathrm{~mm}$ e $1.000 \mathrm{~mm} / \mathrm{ano}$. A composição do Chaco é predominantemente arbórea, com plantas arbustivas e herbáceas espalhadas descontinuamente ao longo de seu território (Pennington et al. 2000).

A configuração espacial atual do Chaco é correlacionada à subsistência da sua extensa planície sedimentar associada ao intenso soerguimento dos Andes na transição entre o Plioceno e Pleistoceno, cerca de 3 a 2 m.a.a. (Zanella 2010).

De acordo com Ab’Saber (1977), os Domínios da Caatinga e do Chaco foram conectados durante os períodos glaciais, pela expansão desses dois domínios em detrimento de áreas de Cerrado do Brasil central. No entanto, análises fitossociológicas abrangendo áreas de vegetação aberta, da região Neotropical, indicam que a Caatinga e o Chaco não foram historicamente conectados, uma vez que o Chaco possui composição 
florística associada às vegetações temperadas secas do extremo sul dos Andes, enquanto a Caatinga possui conexão florística com áreas da região da bacia do Paraná-Paraguai (núcleos Missiones e Piemont, sensu Prado e Gibbs (1993)), da costa Caribenha e com pequenos isolados nos vales secos dos Andes na Bolívia, Peru e Equador.

\subsection{Disjunções dos Domínios Fitogeográficos}

Muitos padrões de disjunção foram descritos para a flora brasileira (Prance 1979; Giulietti e Pirani 1988, 1988; Pirani 1990; Granville 1992; Prado e Gibbs 1993). Em muitos casos esses padrões parecem ser mais o resultado de eventos de dispersão do que conseqüência da fragmentação de uma ampla distribuição ancestral, uma vez que distintas áreas de ocorrência possuem diversidade assimétrica de espécies (Givnish e Sytsma 2000; Lavin et al. 2000). Já em outros casos a distribuição disjunta pode ser adequadamente explicada pela vicariância (Fiaschi e Pirani 2009), por exemplo, estudos de paleoclima e paleovegetação do nordeste do Brasil apontam para a existência prévia de florestas úmidas em áreas hoje ocupadas pelo domínio da Caatinga. A presença atual de florestas de morros (“brejos nordestinos”) neste domínio representa relíquias desta vegetação de florestas úmidas com ampla distribuição na região (Andrade-Lima 1982; De Oliveira, Barreto, and Suguio 1999).

\subsubsection{Sul do Brasil e Andes}

A ocorrência no extremo sul do Brasil de algumas espécies pertencentes a gêneros melhor representados nos Andes tem sido apontada por muitos autores (Rambo 1956; Smith 1962; Waechter 2002; Berry et al. 2004), o que caracteriza uma conexão entre essas duas regiões.

\subsubsection{Campos Rupestres-Restinga}

O termo restinga se refere a vegetação arbustivas de porte baixo e florestas em áreas arenosas de origem recente na costa brasileira (Daly e Mitchell 2000; Thomas e Barbosa 2008). Alguns estudos têm sugerido uma conexão florística entre essas áreas de baixa altitude de restinga e a vegetação dos campos rupestres da Serra do Espinhaço (usualmente encontra-se acima dos 1.000 m) (Giulietti e Pirani 1988) Entre 56 táxons de plantas presumidamente representativas desse padrão de disjunção somente nove (16\%) foram confirmadas como verdadeiras (Alves et al. 2007). A maioria das espécies 
restantes também foi encontrada em planícies no Cerrado e na Floresta Atlântica (Fiaschi e Pirani 2009).

\subsubsection{Disjunções entre as FTSS}

Este padrão de disjunção é característico de espécies vegetais associadas com dois ou mais núcleos de FTSS (Pennington et al. 2000; Prado 2000; de Queiroz 2006; Pennington et al. 2006), entre os quais a Caatinga, a Bacia Paranaense, Missiones e Piedmont respondem pela maioria das espécies encontradas no Brasil. Esse padrão encaixa-se na proposta do Arco-Pleistocênico proposta por Prado e Gibbs (1993).

\subsubsection{Disjunção entre afloramentos rochosos na Floresta Atlântica e montanhas no Cerrado.}

Muitos gêneros e espécies de plantas são trocados entre as “ilhas” de formações abertas de montanhas encontradas entre a Floresta Atlântica e o domínio do Cerrado (Giulietti e Pirani 1988; Di Maio 1996; Safford 1999; Calió et al. 2008). 


\section{Justificativa}

Tanto eventos históricos como ecológicos, assim como as características genéticas de um grupo, são responsáveis pelos padrões de distribuição atual, diversidade das espécies e variações populacionais. Entender esses eventos é possível por meio de uma descrição da quantidade e distribuição da variação genética dentro e entre populações, utilizando modelos da genética de populações e filogeografia. As espécies cactófilas do gênero Drosophila constituem um modelo biológico de interação inseto/planta/leveduras muito importante para estudos populacionais, de interação biológica, evolutivos, sistemáticos e biogeográficos que podem fornecer informações importantes para entender fatores que interferem na distribuição da variação biológica.

Entre as espécies cactófilas, utilizamos a espécie Drosophila buzzatii para entender melhor sua história evolutiva e também traçar rotas migratórias históricas. O interesse nesta espécie está no fato de que, devido as suas características biológicas (Manfrin e Sene 2006), ela tem demonstrado ser uma importante espécie nos mais diversos tipos de estudos genéticos e evolutivos e como um modelo para estudos genômicos (González et al. 2005; Negre et al. 2005; Manfrin e Sene 2006; Kuhn et al. 2007), sendo um representante de um ramo evolutivo distinto dentro do gênero Drosophila, em relação a D. melanogaster; e para estudos evolutivos, pois várias hipóteses, estabelecidas com base em informações de distintos caracteres, existem e podem ser testadas, com um potencial de gerar informações interessantes para compreender a dinâmica das populações e sua evolução (Carreira et al. 2006; Kuhn et al. 2007; Soto et al. 2007). Além destes fatos, decorrentes do acúmulo de conhecimento sobre a espécie, ela apresenta vantagens como modelo biológico para estudos evolutivos populacionais, tais como: a) a espécie é a mais diferenciada e basal dentro do "cluster"; b) apresenta uma dinâmica populacional distinta das outras espécies do grupo; c) ampla distribuição geográfica e em simpatria com várias espécies; d) fácil manutenção em laboratório, quando comparada com outras espécies; e) disponibilidade de marcadores moleculares para estudos populacionais.

Baseados na hipótese de De Brito et al (2002), de que a espécie $D$. buzzatii sofreu um processo natural de dispersão ativa na América do Sul e de que o "centro de origem” da espécie deveria ser revisto, utilizamos marcadores moleculares e os métodos estatísticos mais atuais para tentar delinear como foram esses movimentos de expansão 
populacional, possíveis rotas migratórias e também a área de distribuição da espécie no presente e durante o último período glacial. Desta maneira, este projeto pretendeu gerar informações históricas e recorrentes sobre as populações naturais de $D$. buzzatii, que poderão servir à discussão de dados, por exemplo, sobre interação genótipo/ambiente, adaptação e outros. Além disso, devido ao fato desta espécie ser a mais distinta, tanto em termos morfológicos como biológicos, das outras espécies do “cluster” D. buzzatii, os resultados das análises utilizadas neste trabalho, quando comparados com os dados das outras espécies permitiram testar hipóteses sobre possíveis rotas de expansão e/ou isolamento geográfico de populações, além de investigar ligações fundamentais entre processos populacionais e padrões regionais de diversidade e biogeográficos, com potencial para identificação de áreas isoladas evolutivamente. 


\section{Objetivos}

\subsection{Objetivos Gerais}

O presente trabalho tem por objetivo estudar a estrutura populacional, a história evolutiva, a distribuição da espécie na América do Sul e possíveis rotas de dispersão da espécie Drosophila buzzatii, utilizando seqüências parciais do gene mitocondrial COI e resultados de Modelagem de Nicho Ecológico e Paleomodelagem.

\subsection{Objetivos Específicos}

Os objetivos específicos são: 1- Estimar a variabilidade genética entre e dentro das populações da espécie Drosophila buzzatii; 2- Definir se há estrutura populacional para a espécie $D$. buzzatii; 3- Avaliar o limite de dispersão e fluxo gênico entre as populações; 4- Calcular a taxa de migração, o tempo mínimo de divergência e o sentido da migração entre as localidades amostradas; 5- Utilizando testes de neutralidade, verificar quais os fatores evolutivos que podem estar influenciando a espécie $D$. buzzatii; 6- Utilizando a Modelagem de Nicho Ecológico e Paleomodelagem, gerar mapas da distribuição provável da espécie na América do Sul, no presente e sua provável distribuição durante o último período Glacial (21000 anos) 7- Realizar inferências filogeográficas. 


\section{Material e Métodos}

\subsection{Amostras}

Foram analisados 132 indivíduos pertencentes a 44 localidades ao longo da distribuição da espécie na América do Sul (Figura 3), incluindo os Domínios da Caatinga, Cerrado, Mata Atlântica, Pampas e Chaco. As moscas adultas foram capturadas utilizando armadilhas contendo banana, laranja e a levedura Sacharomices cerevisae. Estas armadilhas foram colocadas próximas a cactáceas em local sombreado e fresco e retiradas de três a cinco dias após sua colocação. Os indivíduos coletados foram recolhidos das armadilhas, com rede entomológica, e transportados ao laboratório em tubos de vidro, com meio de cultura, devidamente etiquetados e acondicionados. No laboratório, os indivíduos machos, identificados através da morfologia do edeago (Vilela 1983; Silva e Sene 1991) como pertencentes à espécie D. buzzatii foram separados e utilizados nas análises subseqüentes.

\subsection{Extração de DNA}

O DNA genômico foi extraído com o conjunto de reagentes Wizard ${ }^{\circledR}$ Genomic DNA Purification Kit (Promega), seguindo as instruções do fabricante. Os indivíduos foram armazenados individualmente em tubos de microcentrífuga contendo uma solução de lise, macerados e homogeneizados. Em seguida foi acrescentadout

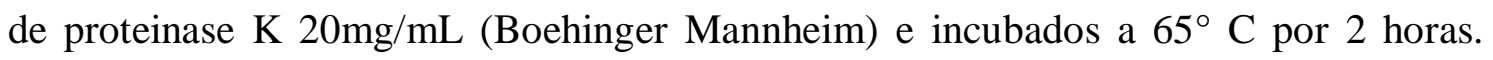
Após está incubação foi adicionada uma solução de precipitação de proteínas ao homogeneizado, incubando-se no gelo por cinco minutos. A solução foi centrifugada por quatro minutos a $4000 \mathrm{~g}$. O sobrenadante contendo DNA foi então removido e transmitido para outro tubo, no qual foi adicionado isopropanol gelado $\left(-21^{\circ} \mathrm{C}\right)$ para a precipitação do DNA e em seguida centrifugado por 5 minutos a 4000g. O DNA precipitado foi lavado em etanol 70\% e diluído em água bi-destilada. 


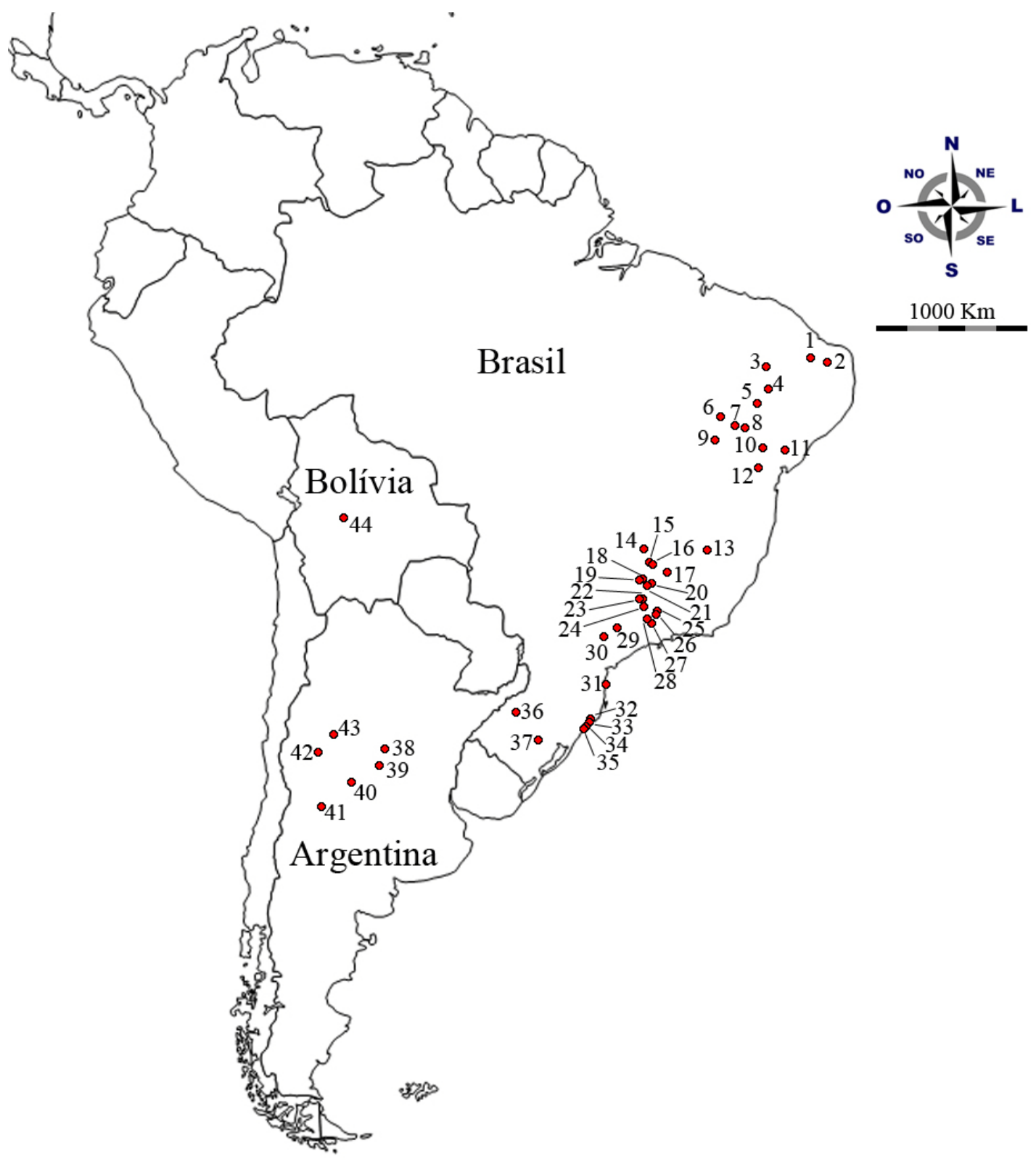

Figura 3. Mapa indicando as populações amostradas da espécie Drosophila buzzatii para o desenvolvimento das análises genéticas. $O$ número correspondente as localidades e seus respectivos nomes estão listados na tabela 1. 


\begin{tabular}{|c|c|c|c|c|c|}
\hline Localização & Estado/País & Longitude & Latitude & Amostra & Domínio \\
\hline 1- Junco do Seridó & PB-Brasil & -36.702222 & -7.006944 & 1 & Caatinga \\
\hline 2- Campina Grande & PB-Brasil & -35.671389 & -7.259722 & 3 & Caatinga \\
\hline 3- Exu & PE-Brasil & -39.983333 & -7.983333 & 4 & Caatinga \\
\hline 4- Juazeiro & BA-Brasil & -40.500000 & -9.416667 & 4 & Caatinga \\
\hline 5- Morro Torre & BA-Brasil & -40.250000 & -9.933333 & 4 & Caatinga \\
\hline 6- Xique-Xique & BA-Brasil & -42.716667 & -10.866667 & 2 & Caatinga \\
\hline 7- Irecê & BA-Brasil & -41.783333 & -11.333333 & 2 & Caatinga \\
\hline 8- Morro do Chapéu & BA-Brasil & -41.168889 & -11.548889 & 3 & Caatinga \\
\hline 9- Ibotirama & BA-Brasil & -43.066667 & -12.266667 & 4 & Caatinga \\
\hline 10- Milagres & BA-Brasil & -39.883333 & -12.850000 & 3 & Caatinga \\
\hline 11- Salvador & BA-Brasil & -38.450000 & -12.950000 & 2 & F. A. NE \\
\hline 12- Manoel Vitorino & BA-Brasil & -40.233333 & -14.133333 & 4 & Caatinga \\
\hline 13- Cardeal Mota & MG-Brasil & -43.583333 & -19.283333 & 2 & Cerrado \\
\hline 14- Nova Ponte & MG-Brasil & -47.683333 & -19.133333 & 7 & Cerrado \\
\hline $\begin{array}{l}\text { 15- Morro Chapéu } \\
\text { MG }\end{array}$ & MG-Brasil & -47.383333 & -20.050000 & 3 & Cerrado \\
\hline 16- Estreito & MG-Brasil & -47.266667 & -20.150000 & 1 & Cerrado \\
\hline 17- Furnas & MG-Brasil & -46.250000 & -20.616667 & 5 & Cerrado \\
\hline 18- Altinópolis & SP-Brasil & -47.900000 & -21.100000 & 3 & Cerrado \\
\hline 19- Sertãozinho & SP-Brasil & -47.966667 & -21.150000 & 2 & Cerrado \\
\hline 20- Cajuru & SP-Brasil & -47.266667 & -21.300000 & 2 & Cerrado \\
\hline 21- São Simão & SP-Brasil & -47.550000 & -21.466667 & 2 & Cerrado \\
\hline 22- Brotas & SP-Brasil & -47.950000 & -22.283333 & 1 & Cerrado \\
\hline 23- Itirapina & SP-Brasil & -47.800000 & -22.266667 & 3 & F. A. \\
\hline 24- Piracicaba & SP-Brasil & -47.683333 & -22.716667 & 2 & F. A. \\
\hline 25- Itatiba & SP-Brasil & -46.838889 & -23.005833 & 1 & F. A. \\
\hline 26- Serra Japi & SP-Brasil & -46.950000 & -23.233333 & 1 & F. A. \\
\hline 27- Ibiuna & SP-Brasil & -47.200000 & -23.733333 & 1 & F. A. \\
\hline 28- Sorocaba & SP-Brasil & -47.566667 & -23.500000 & 2 & F. A. \\
\hline 29- Sengés & PR-Brasil & -49.483333 & -24.083333 & 7 & F. A. \\
\hline 30- Tibagi & PR-Brasil & -50.415278 & -24.513611 & 1 & F. A. \\
\hline 31- Florianópolis & SC-Brasil & -48.421111 & -27.573333 & 1 & F. A. \\
\hline 32- Arroio Teixeira & RS-Brasil & -49.933333 & -29.633333 & 5 & F. A. \\
\hline 33- Capão da Canoa & RS-Brasil & -50.047500 & -29.758611 & 1 & F. A. \\
\hline 34- Osório & RS-Brasil & -50.166667 & -29.883333 & 5 & F. A. \\
\hline 35- Tramandaí & RS-Brasil & -50.216667 & -29.916667 & 5 & F. A. \\
\hline 36- Santiago & RS-Brasil & -54.833333 & -29.183333 & 11 & Pampas \\
\hline 37- Guaritas & RS-Brasil & -53.333056 & -30.748889 & 3 & Pampas \\
\hline 38- Cordoba & Argentina & -64.400000 & -31.400000 & 1 & Chaco \\
\hline 39- La Cruz & Argentina & -64.491944 & -32.307222 & 5 & Chaco \\
\hline 40- San Luis & Argentina & -66.300000 & -33.270000 & 4 & Chaco \\
\hline 41- San Raphael & Argentina & -68.210000 & -34.450000 & 1 & Chaco \\
\hline 42- San Juan & Argentina & -68.410000 & -31.450000 & 3 & Chaco \\
\hline 43- Vale Fertil & Argentina & $\begin{array}{l}-67.474722 \\
\end{array}$ & -30.633056 & 3 & Chaco \\
\hline 44- Cochabamba & Bolívia & -66.120000 & -17.350000 & 2 & Chaco \\
\hline
\end{tabular}




\subsection{Amplificação e isolamento do Gene Mitocondrial Citocromo Oxidase I}

(COI)

Este trabalho foi realizado com as análises do gene mitocondrial COI que apresenta inúmeras vantagens metodológicas, quando utilizado para análises filogeográficas e populacionais (Avise 2000, 2009). O gene mitocondrial Citocromo Oxidase I (COI) possui tamanho aproximado de 1535 pb e correspondem à posição nucleotídica 1533 até 2247 do genoma mitocondrial de Drosophila melanogaster (número de acesso do NCBI GenBank FBgn0013674). Todas as amostras foram amplificadas pela reação de PCR em um volume final de $20 \mu$ l utilizando para isso, tampão contendo 2,0 mM de $\mathrm{MgCl}^{2+}$, 0,2 nmol/ $\mu \mathrm{l}$ de dNTPs, $4 \mathrm{mM}$ de cada oligonucleotídio iniciado, $0,14 \mu \mathrm{l}$ da enzima Taq polimerase (5U/ $\mu \mathrm{l})$ e de 1 a $2 \mu \mathrm{l}$ de DNA genômico. Foram utilizados para a amplificação deste fragmento de gene, os oligonucleotídios iniciadores 1406f (5’CAATTTATCGCCTAACTTCAGCC3') (Simon et al. 1994 modificado por ; De Brito et al. 2002) e 2191r (5’CCCGGTAAAATTAAAATATAAACTTC3') (De Brito et al. 2002). As condições da PCR foram: 1 passo de 1 min e $30 \mathrm{~s}$ a $94{ }^{\circ} \mathrm{C}, 25$ ciclos de $40 \mathrm{~s}$ a $94^{\circ} \mathrm{C}, 40 \mathrm{~s}$ a $54^{\circ} \mathrm{C}$ e $2 \min$ a $72^{\circ} \mathrm{C}$.

\subsection{Purificação dos Produtos de PCR}

Os produtos da PCR obtidos nas etapas de amplificação do gene COI foram checados quanto ao sucesso da amplificação em géis de agarose 1\% em tampão TrisBorato-EDTA (TBE) pH 8,0, corado com brometo de etídio, diretamente aplicado no gel ainda líquido, porém morno. Os produtos de PCR foram aplicados no gel com uma solução de sacarose $(1,2 \mathrm{~g} / \mathrm{ml})$, azul de bromofenol e xileno-cianol e posteriormente foram submetidos à corrida eletroforética, por uma hora, a uma corrente elétrica (amperagem) variando de 60 a $70 \mathrm{~mA}$, e posteriormente, verificados em um transiluminador com luz ultra-violeta para correta checagem do sucesso da amplificação e da qualidade dos produtos.

Os 132 fragmentos utilizados apresentaram concentração aproximada de 20 ng/ $\mu \mathrm{l}$ (estimada por comparação de bandas) e qualidade (sem bandas expúrias) suficientes para serem utilizadas no processo de purificação. A purificação consistiu na remoção dos oligonucleotídios iniciadores e dNTPs utilizados na reação de PCR e que não foram incorporados às seqüências amplificadas. Para a purificação, foram utilizados 
dois protocolos. O primeiro o kit de purificação "GFX PCR DNA and Gel Band Purification Kit” (Amersham Biosciences), seguindo as informações do fabricante, em que os produtos de PCR foram eluídos em soluções do próprio conjunto de reagentes e posteriormente transferidos para uma coluna de purificação, lavados com soluções do próprio conjunto de reagentes e os produtos foram re-suspendidos em água bi-destilada ao fim do processo, na concentração desejada. O segundo protocolo utilizou uma modificação do protocolo proposto por Werle et al. (1994), em que 5 a $7 \mu$ dos produtos de PCR foram incubados com as enzimas "shrimp alkaline phosphatase" (SAP; Pharmacia) e exonuclease I (Exo I; Pharmacia) em um volume variando de 1,5 a 2,6 $\mu \mathrm{l}$, dependendo da concentração estimada dos produtos de PCR. A reação contendo os produtos de PCR e as enzimas foi incubada a $37^{\circ} \mathrm{C}$ por 15 min e em seguida por mais 15 min a $80{ }^{\circ} \mathrm{C}$. Ambos os protocolos apresentaram-se igualmente eficientes para serem utilizados nas reações de seqüenciamento. A concentração e qualidade dos produtos purificados foram verificadas em gel de agarose $1 \%$.

\subsection{Sequenciamento}

A reação de sequenciamento foi realizada com a utilização do conjunto de reagentes ABI PRISM BigDyeTM Terminator Cycle Sequencing Ready Reaction Kit e otimizada para a utilização em um sequenciador automático NBI. A reação de sequenciamento consistiu de $2 \mu \mathrm{l}$ e "Big Dye", 5 pmol d e cad a um d o

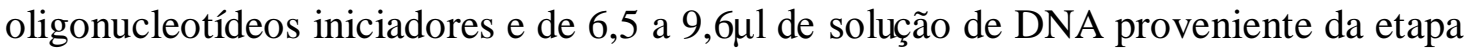
de purificação. Os oligonucleotídios iniciadores utilizados para o sequenciamento direto foram os mesmos utilizados para a amplificação do gene COI. As condições da PCR para o sequenciamento incluíram uma etapa inicial de $2 \mathrm{~s}$ a $96{ }^{\circ} \mathrm{C}$, e 25 ciclos de $10 \mathrm{~s}$ a $96{ }^{\circ} \mathrm{C}, 5 \mathrm{~s}$ a $50^{\circ} \mathrm{C}$ e 4 min a $60{ }^{\circ} \mathrm{C}$. Após a reação foram adicionados aos produtos de PCR $80 \mu \mathrm{de}$ isopropanol 65\%, resfriado a $-21{ }^{\circ} \mathrm{C}$. Em seguida os tubos foram incubados por 15 minutos, na ausência de luz, à temperatura aproximada de $25^{\circ} \mathrm{C}$ e, em seguida, centrifugados por 45 minutos a $4000 \mathrm{rpm}$. O sobrenadante foi removido e as amostras submetidas a duas lavagens com etanol $70 \%$ a $-21{ }^{\circ} \mathrm{C}$. Após a eliminação do etanol, os tubos foram mantidos em uma placa aquecedora a $35{ }^{\circ} \mathrm{C}$ abertos e na total ausência de luz por uma hora ou até a completa evaporação do álcool. 
Para a aplicação das amostras no gel de sequenciamento, estas foram desnaturadas pela adição de $2 \mu 1$ de "Loading buffer", seguido de incubঞ̧ão por 2 min à $95{ }^{\circ} \mathrm{C}$. As amostras foram mantidas no gelo até serem aplicadas no gel.

\subsection{Alinhamento do gene COI}

Sequências “forward” e "reverse” de cada amostra do gene COI foram comparadas, corrigidas e editadas usando o programa “Chromas Lite, 2.0”. Para o alinhamento múltiplo das sequências, foi utilizado o pacote de programas "Bioedit $\mathrm{v}$ 7.0.9” (Hall 1999), o qual inclui o programa “Clustal W, 1.8” (Thompson et al. 1994) e, para garantir a fidelidade da posição dos nucleotídeos das sequencias, os pontos de mutação foram checados a olho, utilizando o programa “Chromas Lite, 2.0” e quando necessário, possíveis erros nas sequencias, interpretados pelo alinhamento como mutação, foram eliminados, novamente a olho, utilizando o programa "Chromas Lite 2.0”. A confirmação da veracidade das sequências obtidas foi realizada pela comparação com informações disponíveis no banco de dados de sequências do NCBI, GenBank utilizando o programa BLAST (Altshul et al. 1997).

\subsection{Análises estatísticas do gene COI}

O modelo HKY + I + G (Hasegawa et al. 1985), seguido pelos modelos Tamura-Ney (1993) foram selecionados, utilizando o critério Akaike (AIC), com o auxílio do programa MEGA 5.0 (Tamura et al. 2007), como os modelos de substituição nucleotídica que melhor explicam a evolução das sequências do gene COI.

\section{8 Índices de diversidade, testes de neutralidade e estimativa do tempo de} expansão populacional.

Utilizando o pacote de programas “Arlequin, 3.5” (Excoffier et al. 2005), foram calculados os índices de diversidade nucleotídica $(\mathbb{t})$, que corresponde ao número médio de diferenças nucleotídicas por sítio entre duas seqüências, e a diversidade haplotípica (Hd), esses dois testes fornecem informações sobre a quantidade de variabilidade presente na amostra. Também foram realizados com este programa os testes de neutralidade $\mathrm{D}$ de Tajima (Tajima 1989), Fs de $\mathrm{Fu}$ (Fu et al. 1997) e a “Mismatch Distribution” (Rogers e Harpending 1992). Já os testes de F* e D* (Fu e Li 1993) foram realizados pelo programa “DnaSP, 5.0” (Rozas et al. 2003) e utilizados 
para verificar se forças evolutivas como efeito carona, expansão populacional e seleção natural estão influenciando o conjunto das amostras.

O teste D de Tajima (Tajima 1989) calcula pelo parâmetro $\theta$, a quantidade de variação acumulada em uma sequência. Esse valor é obtido pela taxa de mutação de uma sequência e pelo tamanho efetivo populacional. Esse parâmetro pode ser estimado através de $\Pi$, que corresponde ao número médio de diferenças nucleotídicas entre duas sequências, escolhidas aleatoriamente na amostra, ou através de $S$, que é o número de sítios polimórficos das sequências amostradas (Tajima 1989). Na neutralidade, os valores de $\theta$ baseados em $\Pi$ e $S$ seriam ap ox mad amente os mesmos. Entretanto quando há seleção natural essas estimativas podem ser distintas, pois a seleção afeta diferentemente $\Pi$ e S. Assim, Tajima (1989) propôs que a diferença (D) enţ,e baseadas em $\Pi$ e S, serviriam como teste para deteção de desvios da neutralidade (D = 0 , sob neutralidade, e $\nexists 0$, sob seleção natural). Portanto, valores negativos e significativos deste teste sugerem que pode ter ocorrido seleção purificadora, efeito carona ou expansão populacional, enquanto valores positivos de D são indicativos de seleção estabilizadora ou contração populacional.

O teste Fs de $\mathrm{Fu}$ (Fu et al. 1997) avalia a probabilidade de existirem k alelos em uma amostra de n sequências dado o valor do, sendo que o valor de Fé obtido pela equação: Fs = ln (S'/1 - S') (Fu et al. 1997, equação 1), onde S' é a probabilidade de existir um número de alelos menor ou igual do que em uma amostra aleatória, dado que $\theta=\pi$ (onde $\pi$ é a diversidade nucleotídica). Assim, em uma amostra com excesso de mutações recentes, o valor de $\theta$ (baseado no valor $\pi$ ) tende a ser menor do que aquele baseado no número de alelos. Portanto, S' pode ser considerado um bom indicador sobre quantidade de mutações recentes na amostra, influenciando o valor de Fs (Fu et al. 1997). O teste Fs só deve ser considerado significante a um nível de 5\% quando os valores de $\mathrm{p}$ forem menores ou iguais a 0,02 e não 0,05, como é o caso da grande maioria dos outros testes de neutralidade. Assim, como o teste D de Tajima, valores negativos e significativos de Fs são um indicativo de expansão populacional, dentre outros eventos (Fu et al. 1997).

Os testes de F* e D* (Fu e Li 1993) partem do princípio de que na presença de seleção purificadora ou negativa há uma tendência de existir um excesso de mutações nos ramos externos de uma genealogia porque alelos deletérios estariam em baixa 
freqüência. Também há um provável excesso de mutações nos ramos externos se um alelo vantajoso foi fixado recentemente na população, porque então é esperado que a maioria das mutações na população seja jovem. Por outro lado, se seleção balanceadora (sobredominância) está operando no locus analisado, então alguns alelos podem ser velhos e assim pode haver deficiência de mutações nos ramos externos. Então, comparando o número de mutações em ramos internos e externos com o esperado para seleção neutra é possível detectar seleção. Estes testes têm maior poder de detecção de seleção de fundo do que o teste D de Tajima (Fu e Li 1993). Dessa maneira ao se utilizar os testes $\mathrm{F}^{*}$ e $\mathrm{D}^{*}$ comparativamente com Fs de Fu e D de Tajima é possível diferenciar seleção de expansão populacional, pois quando temos valores significativos de Fs de Fu e não significativos de $\mathrm{F}^{*}$ e $\mathrm{D}^{*}$ podem ser verificados a provável ocorrência de um evento de expansão de área ou crescimento populacional (Joseph et al. 2002; Peck e Congdon 2004).

A “Mismatch Distribution” é um modelo gráfico de representação de diferenças par a par entre alelos, sendo que um desenho multimodal representa populações em equilíbrio demográfico (o que reflete uma forma altamente estocástica da árvore de genes), enquanto que uma forma unimodal representa populações que passaram por um processo de expansão demográfica (Hudson e Slatkin 1991; Rogers e Harpending 1992) ou por expansão de área, com altos níveis de migração entre demes vizinhos (Ray et al. 2003; Excoffier 2004). A “Mismatch Distribution” é uma maneira gráfica de visualizar a assinatura de um evento de expansão. Desta maneira, se existiu um processo de expansão, então, teoricamente, é possível calcular o tamanho populacional antes da expansão e também o tempo que esta expansão ocorreu. Na “Mismatch Distribution” é assumido que uma população em equilíbrio passou subtamente a t gerações no passado de um tamanho $\mathrm{N}_{0}$ para um tamanho $\mathrm{N}_{1}$ e é representada pela equação:

$$
\text { Fs }\left(\tau, \theta_{0}, \theta_{1}\right)=\text { Fs }\left(\theta_{1}\right)+\exp \left(-\tau\left(\theta_{1}+1\right) / \theta_{1}\right) \Sigma \tau^{\mathrm{j}} / \mathrm{j}^{!}\left[\text {Fs-j }\left(\theta_{0}\right)-\text { Fs-j }\left(\theta_{1}\right)\right]
$$


Onde $\theta_{0}$ é o tamanho populacional antes do evento de expansão e $\theta_{1}$ o tamanho após a expansão, portanto quando $\theta_{0}=\theta_{1}$ podemos dizer que não ocorreu nenhum evento de expansão populacional, entretanto quando $\theta_{0} \neq \theta_{1}$ podemos dizer que, devido a mudança no tamanho populacional pode ter ocorrido um evento de expansão ou redução populacional. A partir dessa informação é possível calcular o tempo desde que esse evento ocorreu. Essa estimativa é realizada utilizando o valor de $\tau$ onde $\tau=2$ ut, t é o tempo em gerações por ano. O valor de u é a taxa de mutação por sequência por geração, calculada neste trabalho como $4,45 \times 10^{-7}$, valor obtido pela comparação entre as sequências de COI de D. melanogaster e D. yakuba, as quais divergiram a aproximadamente 6,1 milhão de anos (Russo et al. 1995; Nagaraju e Ranganath 2004) e o tempo de gerações estimado em 10 gerações por ano (Moraes et al. 2009). Os valores de $\theta_{0}, \theta_{1}$ e $\tau$ foram estimados pela "Mismatch Distribution” e calculados pelo programa “Arlequin, 3.5” (Excoffier et al. 2005), e por meio de um bootstrap paramétrico, foi possível estimar um intervalo de confiança de 95\% para os resultados obtidos e assim foi calculado um valor da soma dos quadrados dos desvios (SSD, sigla em inglês para “Sum of Square Deviations”) em que o valor é considerado significativo no nível de 5\% somente quando os valores de SSD são maiores que 0,95. Os gráficos da "Mismatch Distribution” foram gerados pelo programa “DnaSP, 5.0” (Rozas et al. 2003). A estimativa do tempo de expansão, segundo o modelo de Rogers e Harpending (1992), foi calculada a mão com o auxílio do programa Microsoft Excell 2007.

Para datar eventos de expansão populacional, foi utilizada, além do modelo acima descrito, a "Bayesian Skyline Plot” (BSP), um método baseado na estatística bayesiana, que estima a variação do tamanho efetivo da população ao longo do tempo (Drummond et al. 2005). Esse método utiliza cadeias de Markov (MCMC - Markov Chain Monte Carlo) para estimar a probabilidade a posteriori a partir de um modelo $a$ priori calculado sobre as informações obtidas das sequências fornecidas, assim ele calcula a probabilidade da distribuição do tamanho efetivo da população ao longo do tempo, dado um determinado modelo de substituição nucleotídica e a taxa de mutação da sequência (Drummond et al. 2005; 2007).

A “BSP” foi realizada com o auxílio do programa BEAST, 1.5.4 (Drummond et al. 2005), utilizando o modelo de substituição nucleotídica HKY + I + G (Hasegawa et al. 1985), como proposto pelo programa MEGA, 5.0 (Tamura et al. 2007). O número de interações na MCMC utilizada foi de 500 milhões, amostradas a cada 1000 
interações, com um período de "burn-in" de 10-15\% do total de interações. Foi fixada uma taxa de substituição do gene COI de 1,4\% por milhão de ano. Essa taxa foi calculada baseada nas sequências do COI das espécies D. melanogaster e D. yakuba (Russo et al. 1995; Nagaraju e Ranganath 2004). As análises com o programa BEAST foram realizadas com o auxílio do "Computational Biology Service Unit from Cornell University” (disponível em http://cbsuapps.tc.cornell.edu/beast.aspx). As interações obtidas com o programa BEAST foram analisadas no programa TRACER, 1.5 (Drummond et al. 2005), o qual gera o gráfico da BSP.

O programa "Migrate, 3.2.1” (Beerli e Felsenstein 1999; Beerli e Felsenstein 2001; Beerli 2006) estima o tamanho populacional efetivo e taxas de migração ancestrais entre " $n$ ” populações, assumindo uma matriz de modelos de migração com taxas de mutação assimétricas e tamanhos populacionais diferentes. Esse programa utiliza Máxima Verossimilhança (Maximum Likelihood) ou inferência Bayesiana para calcular diferentes taxas de migração entre subpopulações, o tempo mínimo de divergência e o sentido da migração entre as localidades amostradas. Foi utilizada nas análises, apenas a Máxima Verossimilhança, por ser considerada pelo próprio autor uma análise “mais madura” (Veja Manual do programa página 3, último parágrafo). As amostras foram agrupadas em Domínios para acelerar o processo de geração dos resultados, uma vez que a análise utiliza-se do método Monte Carlo e Cadeia de Markov (Markov Chain Monte Carlo), o qual demanda um grande poder computacional quando se utiliza muitas amostras e localidades.

\subsection{Análises filogeográficas e estrutura populacional}

Foi utilizada a análise de Agrupamento de Clados não Enraizados ou NCPA (sigla em inglês para "Nested Clade Phylogeographic Analysis"), proposta por Templeton et al. (1995; 1998) como um dos métodos para se estimar eventos filogeográficos na espécie $D$. buzzatii. Este método tem como objetivo final, auxiliar nas inferências de possíveis eventos evolutivos influenciados pela distribuição geográfica das amostras, a partir de uma chave de inferência (Templeton et al. 1995; 2004; Panchall e Beaumont 2007), por meio de quatro etapas:

1. O primeiro passo consiste na construção de uma rede de haplótipos não enraizada gerada pelo programa TCS, 1.21 (Clement et al. 2000), a partir de um método de parcimônia estatística com uma probabilidade de 95\% de ser verdadeira. O resultado 
é uma rede onde os haplótipos são conectados uns aos outros por um passo mutacional, e os haplótipos não amostrados são representados por pequenas circunferências (Posada e Crandall 2001). Os haplótipos são proporcionalmente representados por circunferências de tamanhos que variam dependendo de suas freqüências e, em geral, um retângulo representa o haplótipo central ou ancestral. Quando são encontradas reticulações, essas podem ser resolvidas utilizando os critérios descritos em Crandall e Templeton (1993).

2. O segundo passo consiste no aninhamento dos clados, onde os haplótipos observados e inferidos são agrupados hierarquicamente seguindo as regras em Templeton et al. (1987; 1995). Estes agrupamentos são então chamados "clado", sendo que os de primeiro nível são formados pelo agrupamento de haplótipos, já os de segundo nível englobam os de primeiro nível e assim sucessivamente até o agrupamento de toda a rede, formando o "clado total".

3. A partir do aninhamento dos clados, o próximo passo é a verificação significativa ou não da associação entre eles e a posição geográfica. Essa análise usa dois índices: o índice de distância do clado (Dc), que mede a amplitude da distribuição geográfica de um determinado haplótipo, e de distância de clado agrupado (Dn), que mede a distância média dos haplótipos de determinado clado em relação ao centro geográfico da distribuição dos haplótipos do clado do próximo nível de agrupamento. A relação entre esses testes permite testar a hipótese nula de não associação da genealogia com a distribuição geográfica da espécie (Templeton et al. 1995; 1998). Os testes de significância foram realizados com 5000 permutações e os valores de Dc e Dn foram estimados pelo programa GeoDis, 2.0 (Posada et al. 2000).

4. Os resultados significativos gerados pelo programa GeoDis, 2.0 foram interpretados utilizando uma chave de inferência fornecida em Templeton (2004). Essa chave de inferência permite a detecção de prováveis eventos históricos e/ou recorrentes responsáveis pela associação significante entre os dados genéticos e geográficos.

A NCPA é um método muito utilizado para análises filogeográficas, entretanto vem sendo extensivamente criticado nos últimos anos (Panchal e Beaumont 2007; Knowles 2008; Petit 2008; Nielsen e Beaumont 2009). As maiores críticas a esse método foram relatadas no trabalho de Panchall e Beaumont (2007), numa tentativa de se automatizar esse método, usando simulações, foi observado que em $75 \%$ dos casos, à 
análise produzia resultados falso-positivos quando a resposta a análise era o isolamento por distância, o resultado mais comum dos trabalhos utilizando essa análise. Templeton (2009) rebateu essa crítica e demonstrou que a análise combinada de multilocus era capaz de resolver o problema dos resultados falso-positivos. Mas o isolamento-pordistância também pode ser verificado utilizando outros métodos estatísticos como o teste de Mantel, o qual testa a correlação ou as correlações parciais entre 2 ou 3 matrizes por meio de um processo permutacional (Mantel 1967; Smouse et al. 1986). Desta maneira, para validar possíveis resultados de isolamento-por-distância, gerados pela NCPA, foi realizado o Teste de Mantel correlacionando uma matriz de valores de Fst (Wright 1931), um teste de estruturação populacional, com uma matriz de distâncias geográficas. As distâncias geográficas em quilômetros entre cada ponto foram calculadas com o auxílio do programa Excell (Microsoft) por meio da equação abaixo, a qual leva em consideração a curvatura da Terra para medir a distância entre duas coordenadas geográficas quaisquer, desde que estejam em graus decimais:

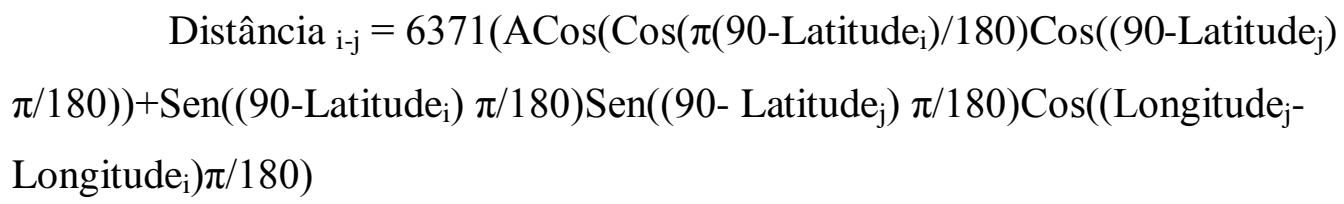

O teste de Mantel foi realizado com auxílio do programa “Arlequin, 3.5” (Excoffier et al. 2005), em que foi gerada a matriz de valores de Fst e comparadas com a matriz de distâncias geográficas.

Para testarmos a existência de estrutura populacional, além do teste de Fst de Wright (1931), também foi realizada uma Análise de Variância Molecular (AMOVA) (Excoffier et al. 1992). Esta análise realiza estimativas de componentes de variância dentro e entre grupos previamente estabelecidos e fornece valores de $\Phi$, que refletem a correlação da diversidade haplotípica em diferentes níveis hierárquicos (Excoffier et al. 1992). O Фst corresponde a covariância entre indivíduos dentro de populações, oФsc é a covariância entre populações dentro de um grupo e Фct corresponde a covarência entre grupos. Para a realização dessa análise, as amostras foram agrupadas em Domínios (Caatinga, Floresta Atlântica, Floresta Atlântica Ne, Cerrado, Pampas e Chaco), onde os pontos geográficos foram incluídos em seus respectivos Domínios, delimitados por mapas propostos pelo Instituto Brasileiro de Geografia e Estatística (IBGE) e também por informações adicionais e observação pessoal. A AMOVA foi realizada pelo 
programa “Arlequin, 3.5” (Excoffier et al. 2005) com 16.000 permutações e o modelo de substituição nucleotídica utilizado foi Tamura-Nei.

\subsection{Modelagem de nicho ecológico e Paleomodelagem}

Com o intuito de compreender a dinâmica dos movimentos da espécie $D$. buzzatii, foram produzidas e comparadas projeções da probabilidade de ocorrência desta espécie em duas situações: sua distribuição atual e durante o último período glacial, há cerca de 21.000 anos. A comparação dessas projeções pôde auxiliar na compreensão dos caminhos seguidos pela $D$. buzzati durante períodos de climas mais secos, considerados favoráveis para a expansão de sua área de ocorrência e em períodos mais úmidos, como o atual, onde a espécie, em teoria, estaria confinada em resquícios da sua distribuição em condições mais favoráveis. Para a geração dessas projeções foram utilizados 132 coordenadas geográficas, onde foram englobadas as 44 localidades utilizadas para as análises genéticas e outras 88 localidades obtidas de coletas previamente realizadas, além de coordenadas geográficas de outros trabalhos (Appendice 1). As projeções foram calculadas utilizando o algoritmo de Entropia Máxima (Maximum Entropy), implementado no programa MaxEnt (Phillips et al. 2006). Este algoritmo utiliza Máxima Verossimilhança para criar um modelo com todas as informações fornecidas, não assumindo nenhuma informação desconhecida. Assim, ele gera uma coleção de fatos sobre o modelo consistente da maneira mais uniforme possível. Para as projeções da área de ocorrência no presente, foram utilizados mapas com resolução espacial de 30 arco-segundos, onde cada "pixel" do mapa corresponde a um quadrado de um quilômetro de lado. Para as projeções do último período glacial, foram utilizados dois modelos de previsões: o modelo gerado pela "Comunidade de Sistemas de Modelos Climáticos” (Community Climate System Model - CCSM) e o modelo gerado pelo grupo “Modelos para Pesquisa Interdisciplinar do Clima” (Model for Interdisciplinary Research On Climate - MIROC), ambos disponíveis em: http://www.worldclim.org/past, com resolução de 2,5 arco-minutos, em que cada pixel corresponde a um quadrado de cinco quilômetros de lado. Para o desenvolvimento das projeções foi utilizada uma camada com as medidas de altitude, com exceção dos modelos do passado onde a camada de altitude não foi utilizada devido à diminuição do nível do mar (Clapperton et al. 1993), e camadas com as seguintes condições bioclimáticas: amplitude média diurna (mean diurnal range), sazonalidade da temperatura, temperatura máxima do mês mais quente, temperatura mínima do mês 
mais frio, amplitude anual de temperatura, precipitação anual, sazonalidade da precipitação, precipitação do quarto mais úmido, precipitação do quarto mais quente (Hijmans et al. 2005; Thomé et al. 2010) e também, precipitação do quarto mais seco e precipitação do quarto mais frio. Essas camadas foram escolhidas por representarem condições favoráveis à presença da espécie D. buzzatii em seu ambiente natural. A função “dontextrapolate” foi utilizada no programa MaxEnt para evitar projeções espúrias (Giovanelli et al. 2008; Thomé et al. 2010). Também foi utilizado o critério de mínima presença para a definição do limiar que é igual ao valor mínimo para a existência da espécie em determinada localidade, portanto, os valores de probabilidade inferiores ao limiar foram transformados em zero, e um mapa binário foi produzido. A acurácia dos modelos foi checada considerando que 75\% das coordenadas geográficas utilizadas seriam pontos de treino, ou seja, coordenadas que representam a presença real da espécie na localidade amostrada, e que $25 \%$ das coordenadas foram utilizadas para a validação do modelo, retiradas e testadas quanto a sua presença. Essa validação do modelo resulta em um valor da área sob a curva (Area Under Curve - AUC) (Fielding e Bell 1997; Manel et al. 2001), que pode variar de 0,5 para acurácea aleatória até 1,0 que seria a discriminação perfeita.

Trabalhos que relatam os acontecimentos ocorridos anteriormente ao último período glacial (21.000 anos atrás) são raros e escassos. Neste trabalho utilizamos o último período glacial (Wisconsin) como base para extrapolar o que pode ter ocorrido com a espécie, utilizando as informações desse período para explicar o que foi encontrado em outros períodos glaciais. Também consideramos um relaxamento na datação dos períodos glaciais, pois, as informações do tempo exato do início e termino desses eventos não são exatos e muitas vezes contraditórios. 


\section{Resultados}

\subsection{Estatística descritiva}

Dos 714 pares de base da primeira metade do gene COI sequenciados, de 132 indivíduos pertencentes à espécie Drosophila buzzatii, foram encontrados 36 haplótipos, resultado de 41 sítios polimórficos, sendo que destes, 10 haplótipos são exclusivos do domínio da Caatinga, oito da Floresta Atlântica, seis do domínio do Cerrado, cinco do Chaco e três dos Pampas. Quanto à freqüência, o haplótipo 01 apresentou-se em 58,95\% dos indivíduos e o haplótipo 25 em 6,71\%, já os demais haplótipos apresentaram freqüência inferior a 5\%. A proporção de bases encontradas nas sequências obtidas foi: $\mathrm{C}=17,12 \%, \mathrm{~T}=37,44 \%, \mathrm{~A}=28,76 \%$, e $\mathrm{G}=16,69 \%$.

O resultado da análise para definir o modelo de substituição nucleotídica, realizado pelo program MEGA, 5.0, monstrou que o melhor modelo a ser utilizado neste conjunto de dados é o HKY, seguido do modelo de Tamura-Nei. Desta maneira, sempre que foi possível aplicar o modelo HKY ele foi utilizado, quando essa opção não era permitida, utilizou-se o modelo de Tamura-Nei.

Na tabela 2 estão resumidos os resultados dos índices de diversidade encontrados para a espécie $D$. buzzatii em todos os Domínios analisados e também o resultado encontrado para a espécie como um todo.

Table 2. Índices de diversidade nucleotídica e diversidade haplotípica de sequencias do gene mitocondrial COI obtidos para a espécie D. buzzatii.

\begin{tabular}{|l|l|l|l|}
\hline \multicolumn{2}{|l|}{} & \multicolumn{2}{|l|}{ Índices de Diversidade } \\
\hline Domínios & $\begin{array}{l}\text { Número } \\
\text { de } \\
\text { indivíduos }\end{array}$ & $\begin{array}{l}\text { Diversidade } \\
\text { Haplotípica }(h)\end{array}$ & $\begin{array}{l}\text { Diversidade nucleotídica } \\
(\pi)\end{array}$ \\
\hline Caatinga & 34 & 0.8039 & 0.0030 \\
\hline Cerrado & 31 & 0.6215 & 0.0020 \\
\hline Floresta Atlântica & 32 & 0.4899 & 0.0019 \\
\hline Floresta Atlântica NE & 2 & 0.0000 & 0.0000 \\
\hline Pampas & 14 & 0.3956 & 0.0011 \\
\hline Chaco & 19 & 0.3860 & 0.0004 \\
\hline Total & 132 & 0.6192 & 0.0022 \\
\hline
\end{tabular}


Dentre os domínios amostrados, a Caatinga apresentou os maiores valores da diversidade nucleotídica $(t=0,002946)$, sendo que os valores foram decrescendo em uma clina norte/sul seguida pelos domínios do Cerrado $(\pi=0.0020)$, Floresta Aâhtica $(\pi=$ 0.0019), Pampas $(\pi=0,0011)$ e Chaco $(\pi=0,0004)$. Resultados semelhantes foram encontrados para a diversidade haplotípica $(h)$ como pode ser verificado pelos resultados apresentados na tabela 1 .

\subsection{Rede de haplótipos e Nested Clade Phylogeographic Analysis (NCPA)}

Utilizando o programa TCS, 1.21 (Clement et al. 2000) foi gerada uma rede de haplótipos não enraizada para a espécie D. buzzatii (Figura 4). Essa rede apresentou-se na conformação conhecida como forma de estrela (Star Shape), onde existe um ou poucos haplótipos com frequencias elevadas e muitos haplótipos diferindo por uma ou poucas mutações, o que indica evento de expansão populacional (Avise 2000).

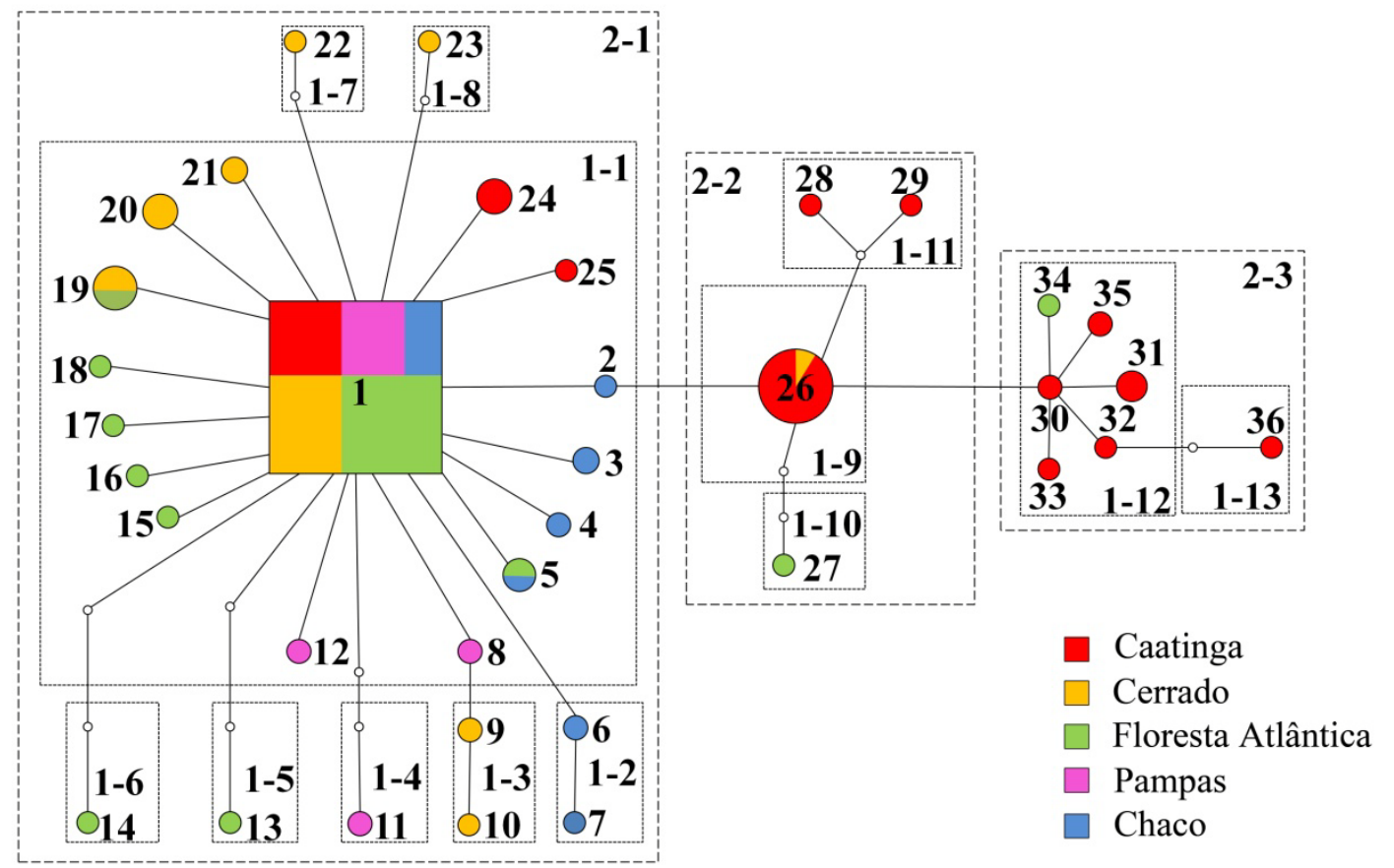

Figura 4. Rede de haplótipos em forma de estrela, gerada pelo programa TCS a partir das sequencias geradas para o gene mitocondrial COI de $D$. buzzatii. O retângulo representa o haplótipo ancestral e os círulos são proporcionais a frequencia dos haplótipos. Linhas contínuas representam aninhamento de primeiro nível e descontínuas, aninhamentos de segundo nível. Números separados por hífen representam agrupamentos utilizados para a análise da NCPA e as cores representam os domínios aos quais os haplótipos pertencem. 
A rede de haplótipos aninhada, segundo procedimento descrito em Templeton (1998), resultou em 13 clados de primeiro nível e três clados de segundo nível (Figura 4). Os aninhamentos foram testados por meio de um teste de significância entre suas posições geográficas e relação de proximidade genética, pelo programa GeoDis, 2.0 (Posada et al. 2000). Foram obtidos resultados significativos para o haplótipo 20, os clados 1-2, 1-3 e clado 2-1. Os resultados obtidos a partir da utilização da chave de inferência de Templeton (2004) para a determinação dos prováveis eventos histórico/demográficos que explicam a associação genética/demográfica dos clados estão resumidos na tabela 3.

Tabela 3. Resultados obtidos por meio da utilização de uma chave de inferência para associação geográfica e genética dos clados significativamente associados, obtida de Templeton (2004).

\begin{tabular}{|l|l|l|}
\hline Amostra/Clado & $\begin{array}{l}\text { Passos da chave de } \\
\text { inferência }\end{array}$ & Conclusão \\
\hline Haplótipo 20 & $1-2-3-4-N a ̃ o$ & $\begin{array}{l}\text { Fluxo gênico restrito com } \\
\text { isolamento por distância. }\end{array}$ \\
\hline Clado 1-2 & $\begin{array}{l}\text { Fluxo gênico / dispersão, } \\
\text { mas com alguma dispersão } \\
\text { a longa distância. }\end{array}$ \\
\hline Clado 1-3 & $1-2-3-4-N a ̃ o$ & $\begin{array}{l}\text { Fluxo gênico restrito com } \\
\text { isolamento por distância. }\end{array}$ \\
\hline Clado 2-1 & $\begin{array}{l}\text { Fluxo gênico restrito com } \\
\text { isolamento por distância. }\end{array}$ \\
\hline
\end{tabular}

O resultado do coeficiente de correlação do teste de Mantel foi de 0,1261, p = 0,048, apresentando uma correlação significativa entre as duas medidas analisadas e portanto podemos confirmar a existência de isolamento por distância na espécie $D$. buzzatii.

\subsection{Estruturação populacional AMOVA e Fst}

Os resultados da AMOVA considerando as amostras agrupadas em Domínios (Caatinga, Floresta Atlântica, Floresta Atlântica Ne, Cerrado, Pampas e Chaco) demonstraram que 68,33 \% da variação encontrada é devido à variação dentro das populações, 24,55\% da variação entre populações dentro dos domínios e 7,12\% entre 
domínios. Os valores de $\Phi_{\mathrm{SC}}, \Phi_{\mathrm{ST}}$, e $\Phi_{\mathrm{CT}}$ foram todos altamente significativos (Tabela 4), indicando a existência de estruturação populacional entre os domínios amostrados.

Tabela 4. Resultado do teste AMOVA considerando as amostras das populações de $D$. buzzatii agrupadas em domínios fitogeográficos.

\begin{tabular}{|l|l|l|l|}
\hline Fonte da variação & Soma dos quadrados & $\begin{array}{l}\text { Componentes da } \\
\text { variação }\end{array}$ & $\begin{array}{l}\text { Porcentagem da } \\
\text { variação }\end{array}$ \\
\hline Entre Domínios & 10,456 & 0,04603 & 7,12 \\
\hline $\begin{array}{l}\text { Entre populações } \\
\text { dentro dos Domínios }\end{array}$ & 33,454 & 0,15865 & 24,55 \\
\hline Dentro das populações & 38,711 & 0,44152 & 68,33 \\
\hline Total & 82,622 & 0,64620 & NA \\
\hline
\end{tabular}

$\Phi_{\text {SC }}: 0,26434 \mathrm{p}<0.01$

$\Phi_{\mathrm{ST}}: 0,31675 \mathrm{p}<0.01$

$\Phi_{\mathrm{CT}}: 0,07124 \mathrm{p}<0.01$

O teste de Fst realizado considerando o agrupamento utilizado na AMOVA demonstrou que somente os domínios da Caatinga e Floresta Atlântica NE apresentamse estruturados geneticamente (Tabela 5).

Tabela 5. Resultados do teste Fst considerando as amostras analisadas das populações de $D$. buzzatii agrupadas em domínios fitogeográficos. Diagonal esquerda, valores gerados pelo teste. Diagonal direita, em negrito, valores de significância.

\begin{tabular}{|c|c|c|c|c|c|c|}
\hline Domínio & Chaco & Pampa & $\begin{array}{c}\text { Floresta } \\
\text { Atlântica }\end{array}$ & $\begin{array}{c}\text { Floresta } \\
\text { Atlântica } \\
\text { NE }\end{array}$ & Cerrado & Caatinga \\
\hline Chaco & 0.0000 & $\mathbf{0 . 1 4 4 1}$ & $\mathbf{0 . 9 8 1 9}$ & $\mathbf{0 . 0 0 0 0} *$ & $\mathbf{0 . 3 8 7 4}$ & $\mathbf{0 . 0 0 0 0 *}$ \\
\hline Pampa & 0.0097 & 0.0000 & $\mathbf{0 . 6 0 3 6}$ & $\mathbf{0 . 0 5 4 0}$ & $\mathbf{0 . 7 0 2 7}$ & $\mathbf{0 . 0 0 0 0 *}$ \\
\hline $\begin{array}{c}\text { Floresta } \\
\text { Atlântica }\end{array}$ & -0.0143 & -0.0055 & 0.0000 & $\mathbf{0 . 1 0 8 1}$ & $\mathbf{0 . 1 1 7 1}$ & $\mathbf{0 . 0 0 0 0 *}$ \\
\hline $\begin{array}{c}\text { Floresta } \\
\text { Atlântica NE }\end{array}$ & 0.8266 & 0.6209 & 0.4149 & 0.0000 & $\mathbf{0 . 0 2 7 0} *$ & $\mathbf{0 . 0 2 7 0}^{*}$ \\
\hline Cerrado & 0.0063 & -0.0105 & 0.0092 & 0.3749 & 0.0000 & $\mathbf{0 . 0 0 0 0 *}$ \\
\hline Caatinga & 0.1944 & 0.1665 & 0.1384 & 0.3554 & 0.1688 & 0.0000 \\
\hline
\end{tabular}

* Valor de significância para alfa $=0.05$

Valores de Fst foram calculados comparando cada localidade, a fim de se obter um refinamento do nível de estruturação genética e de definir o nível de fluxo gênico 
entre elas para identificar as populações estruturadas geneticamente. Os resultados demonstraram que a maior parte das populações que apresentam estruturação encontrase na Caatinga (Tabela 6). 


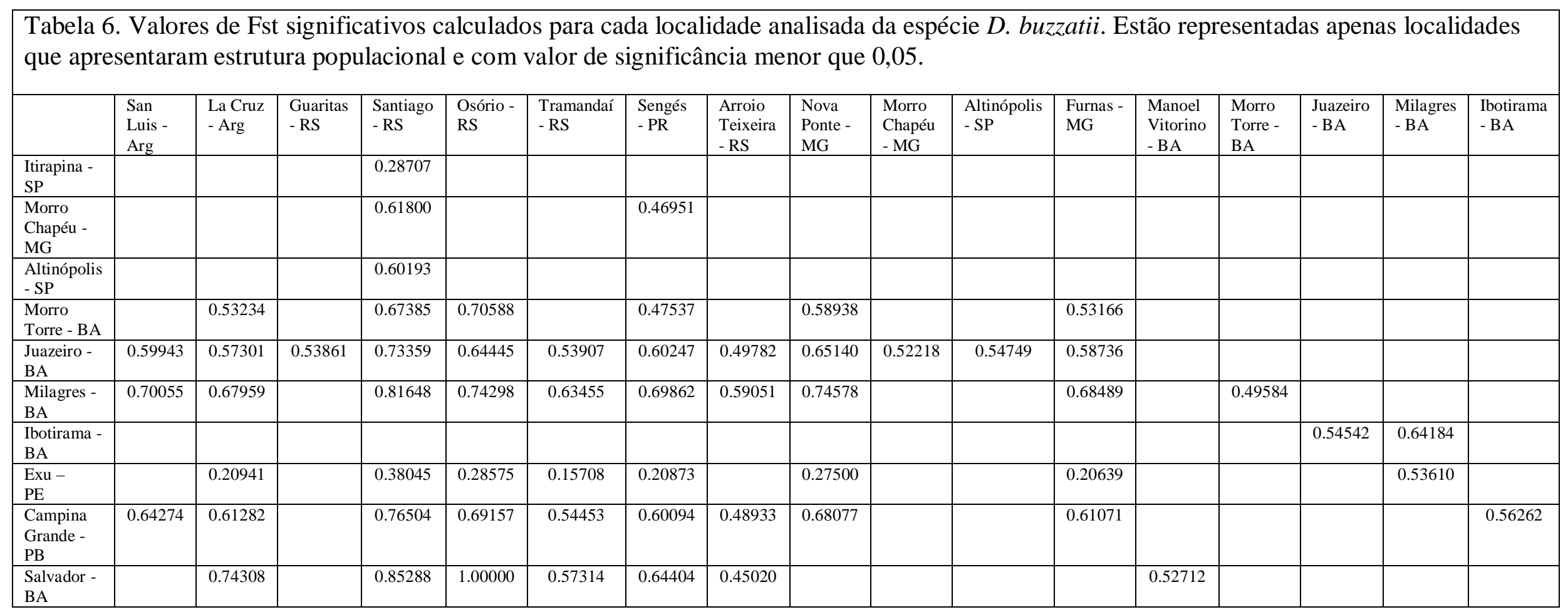




\subsection{Testes de neutralidade e "Mismatch Distribution"}

Os resultados dos testes de neutralidade D de Tajima e Fs de Fu apresentaram valores negativos e altamente significativos para a espécie $D$. buzzatii, indicando que algum evento possa ter aumentado a freqüência de mutações recentes. Os mesmos testes foram aplicados para cada domínio em separado. Os resultados obtidos foram valores negativos e significativos do teste D de Tajima nos domínios do Cerrado, Mata Atlantica e Pampas (Tabela 7), entretanto, os resultados do Fs de Fu foram significativos e negativos para os domínios da Caatinga, Cerrado, Mata Atlântica e Chaco. Esses resultados nos mostram que pode ter ocorrido uma série de eventos como seleção por varredura (Selective Sweep), seleção de fundo (Background Selection), aumento populacional ou expansão de área. O refinamento desses resultados foi realizado comparando-se os valores de $\mathrm{D}^{*}$ e $\mathrm{F}^{*}$ para cada domínio, pois crescimento populacional ou expansão de área podem ser distinguidos de eventos de seleção quando comparamos os valores de D* e F* com os testes de Fs de Fu e D de Tajima (Fu et al. 1997). Eventos de expansão de área são prováveis de terem ocorrido quando temos valores significativos de $\mathrm{Fs}$ de $\mathrm{Fu}$ ou $\mathrm{D}$ de Tajima e não significativos de $\mathrm{D}^{*}$ e $\mathrm{F}^{*}$, o contrário indica seleção (Fu et al. 1997; Joseph et al. 2002; Peck et al. 2004). Desta maneira, ao se verificar os resultados da tabela 7 , pode-se concluir que eventos de expansão populacional ocorreram nos domínios da Caatinga, Cerrado e Chaco.

\begin{tabular}{|l|l|l|l|l|l|}
\hline \multicolumn{6}{|l|}{$\begin{array}{l}\text { Tabela 7. Resultados dos testes de neutralidade realizados para sequencias do gene } \\
\text { mitocondrial COI na espécie D. buzzatii. }\end{array}$} \\
\hline \multicolumn{7}{|l|}{\begin{tabular}{l} 
Índices de Neutralidade \\
\hline Domínios \\
\end{tabular}} & $\begin{array}{l}\text { Número de } \\
\text { indivíduos }\end{array}$ & D de Tajima & Fs de Fu & D* & F $^{*}$ \\
\hline Caatinga & 34 & -1.1325 & $-6.4022^{* *}$ & $-1,234$ & $-1,432$ \\
\hline Cerrado & 31 & $-1.9577^{* *}$ & $-4.9310^{* *}$ & -1.596 & -2.001 \\
\hline Floresta Atlântica & 32 & $-2.3538^{*}$ & $-5.7081^{* *}$ & $-3.079^{*}$ & $-3.257^{*}$ \\
\hline Floresta Atlântica NE & 2 & 0.0000 & NA & & \\
\hline Pampas & 14 & $-1.7976^{*}$ & -1.1512 & $-2.274^{*}$ & $-2.449^{*}$ \\
\hline Chaco & 19 & -1.5108 & $-3.5706^{* *}$ & -1.658 & $-1,797$ \\
\hline Total & 132 & $-2.4150^{* *}$ & $-28.6719^{* *}$ & $-3.889^{*}$ & $-3.959^{*}$ \\
\hline
\end{tabular}

* Resultados significativos para alfa $=0.05$

** Resultados significativos para alfa $=0.01$ 
Os resultados das análises de "Mismatch Distribution” geraram uma curva unimodal quando todas as populações de $D$. buzzatii foram analisadas em conjunto, o que sugere evento de expansão populacional (Figura 5). Este teste aplicado para cada domínio separadamente resultando em curvas unimodais para os domínios da Caatinga, Cerrado, Chaco e Pampas, indicando que esses domínios sofreram um evento de expansão populacional. Entretanto o domínio da Floresta Atlântica apresentou curvas multimodais, sugerindo estabilidade populacional. O agrupamento da Floresta Atlântica NE não gerou resultados da “Mismatch Distribution”, pois possui apenas um haplótipo. 


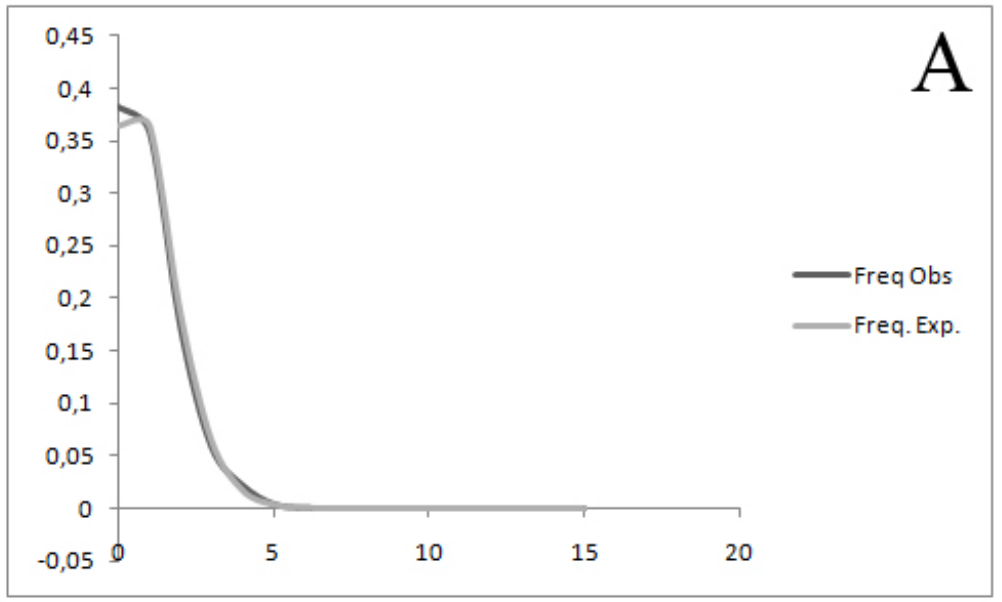

D. buzzatii

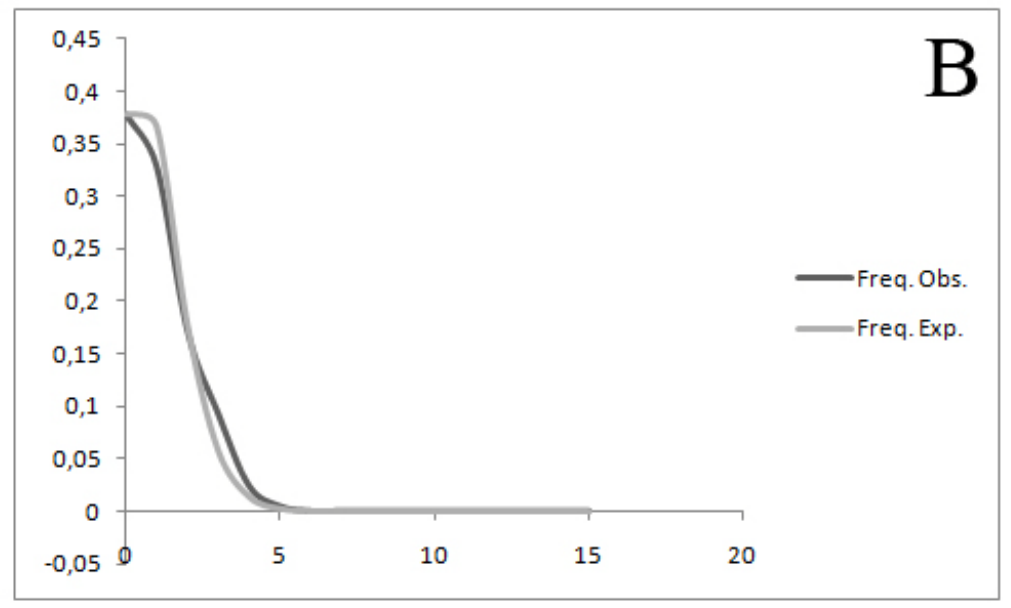

\section{Cerrado}

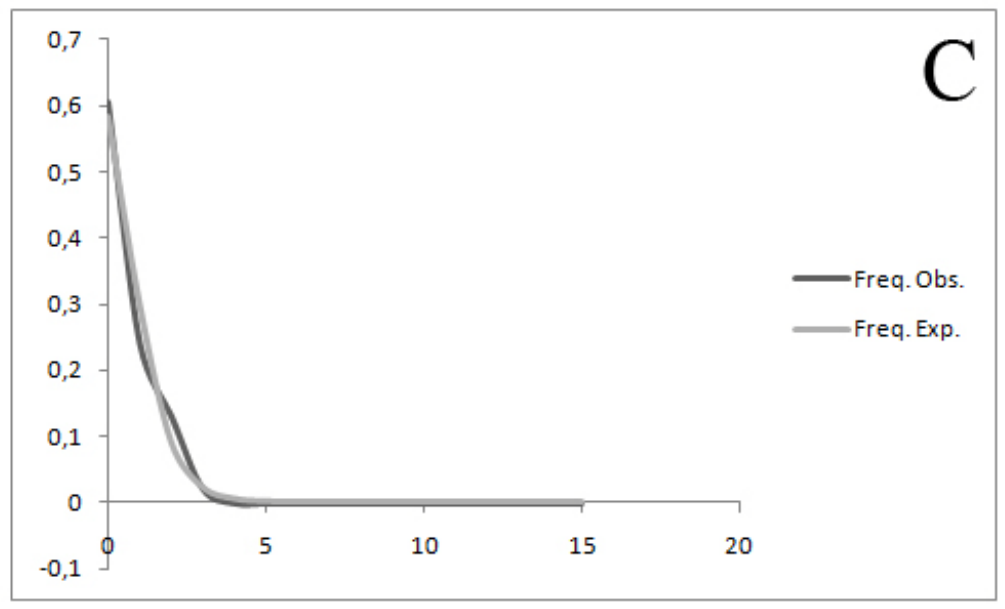

Pampas 


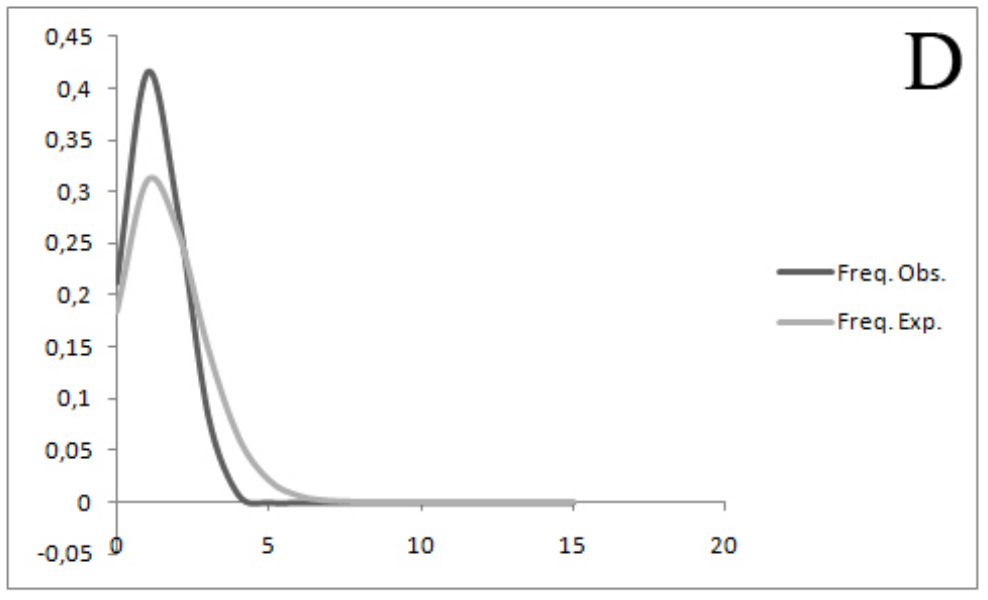

Caatinga

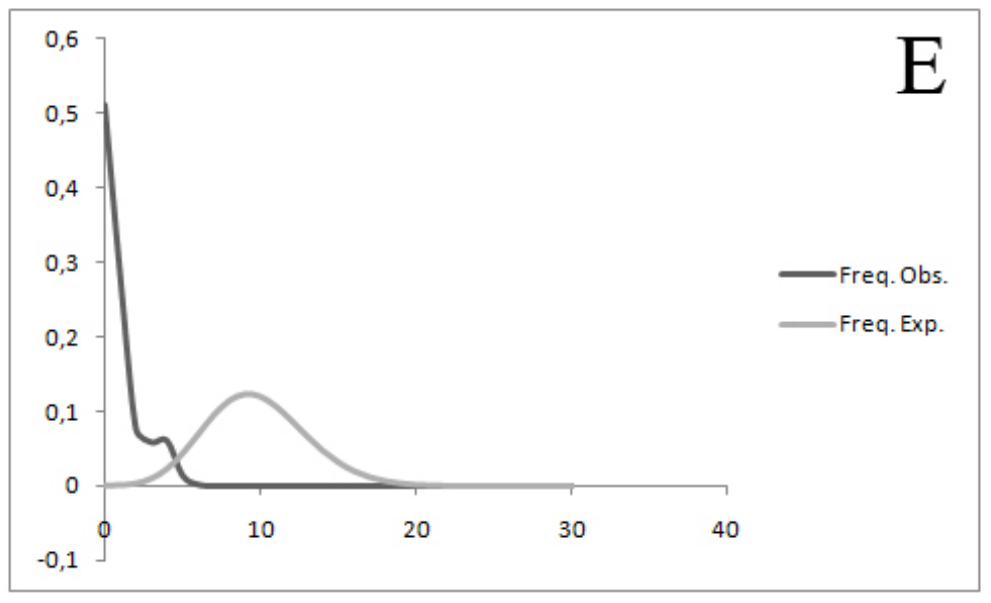

Floresta Atlântica

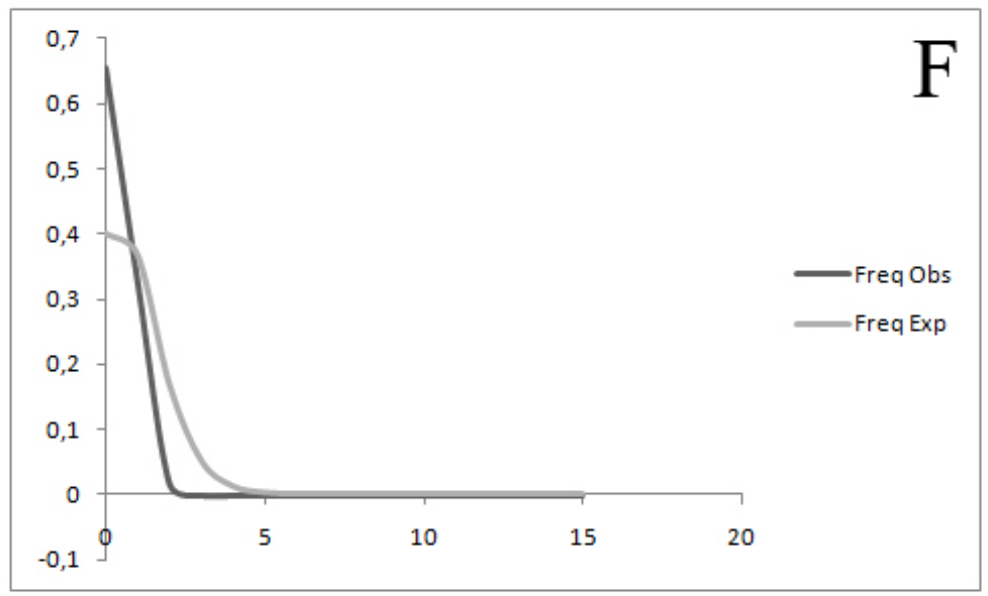

\section{Chaco}

Figura 5. Resultados da "Mismatch distribution" para amostras da espécie D. buzzatii. "A" resultado considerando todas as amostras analisadas em conjunto. "B - F" resultados obtidos na análise considerando os domínios fitogeográficos. 


\subsection{Estimativas do tempo de expansão populacional}

\subsubsection{Mismatch Distribution e Inferência Bayesiana}

Para os movimentos de expansões populacionais detectados, foram aplicados métodos para estimar o tempo em que esses eventos ocorreram. Em ambos os métodos foram calculados os tempos da amostra como um todo e também dividida em domínios. Para a amostra como um todo, o tempo estimado pela análise da "Mismatch Distribution" foi de aproximadamente 494.269 anos atrás, já o resultado da "BSA" foi em torno de 550.000 a 650.000 anos atrás (Figura 6).

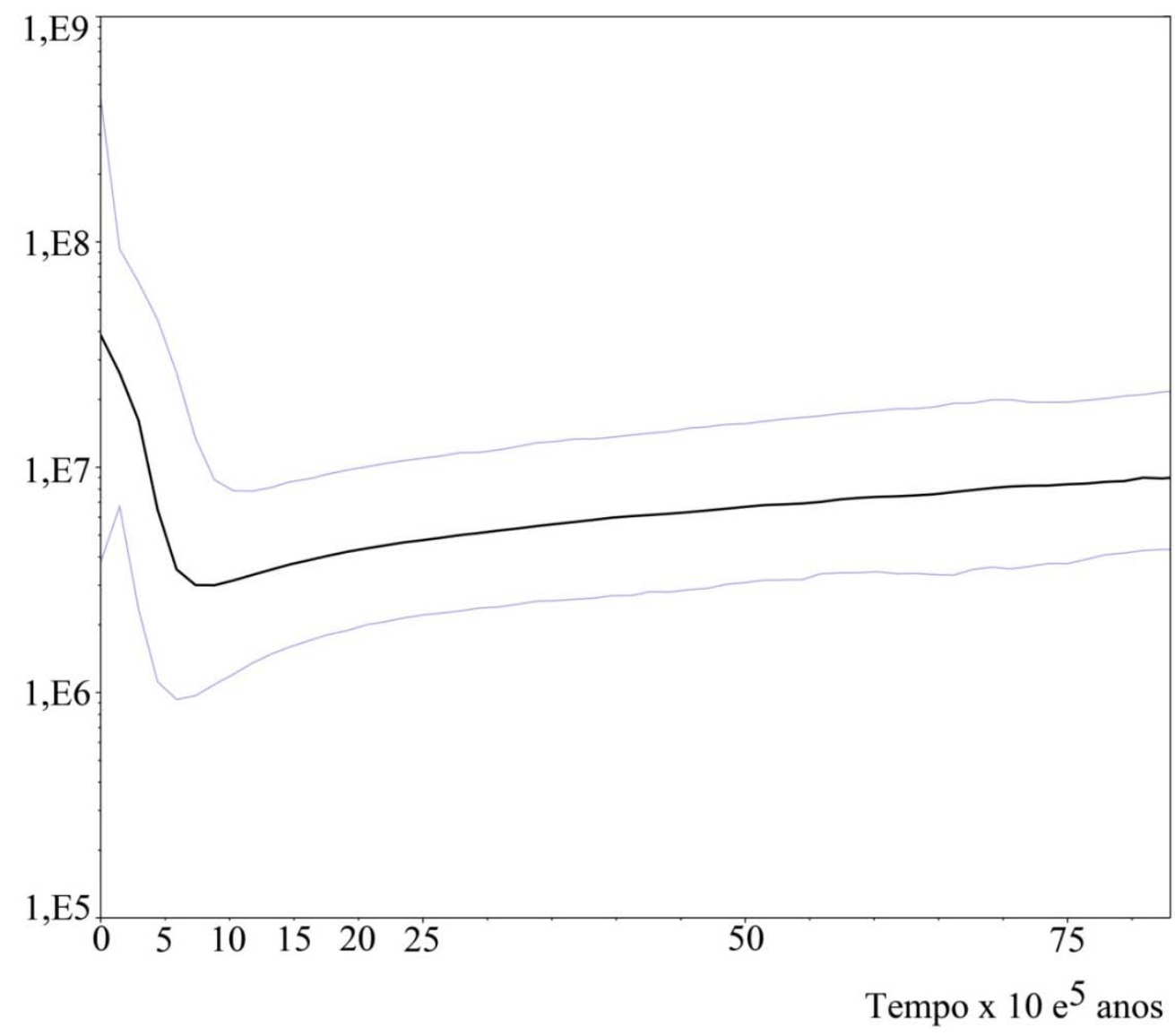

Figura 6. Resultados da Bayesian Skyline Analyses para populações de $D$. buzzatii onde pode ser observado um crescimento populacional em torno de 550000 a 650000 anos atrás. No eixo horizontal, tempo em anos $\times 10 \mathrm{e}^{5}$. No eixo vertical número efetivo de indivíduos.

Os tempos estimados pelo método da "Mismatch Distribution" com índice de confiança de 95\% foram: Caatinga - 288.798, Cerrado - 297.357, Floresta Atlântica 27.431, Pampas - 35.112 e Chaco - 122.453 anos atrás. Já os valores estimados pela "BSA" foram: Caatinga - 510.000, Cerrado - 240.000, Floresta Atlântica - 295.000, 
Pampas - 190.000 e Chaco - 270.000 anos atrás. Os indivíduos pertencentes à Floresta Atlântica NE não foram utilizadas, pois as sequencias desta localidade não apresentam variação o que inviabiliza este tipo de análise. Esses resultados foram plotados conjuntamente em um gráfico, onde as proporções de cada análise foram mantidas, assim como a escala onde foram gerados. Foram acrescentados ao gráfico com os tempos estimados pela "BSA", prováveis eventos de resfriamento das condições ambientais do planeta. Esses eventos foram estimados a partir de uma revisão anual feita por Gibbard e Kohen (2008), onde a versão mais atual pode ser encontrada em online através do sítio: http://www.quaternary.stratigraphy.org.uk/correlation/chart.html (Figura 7).

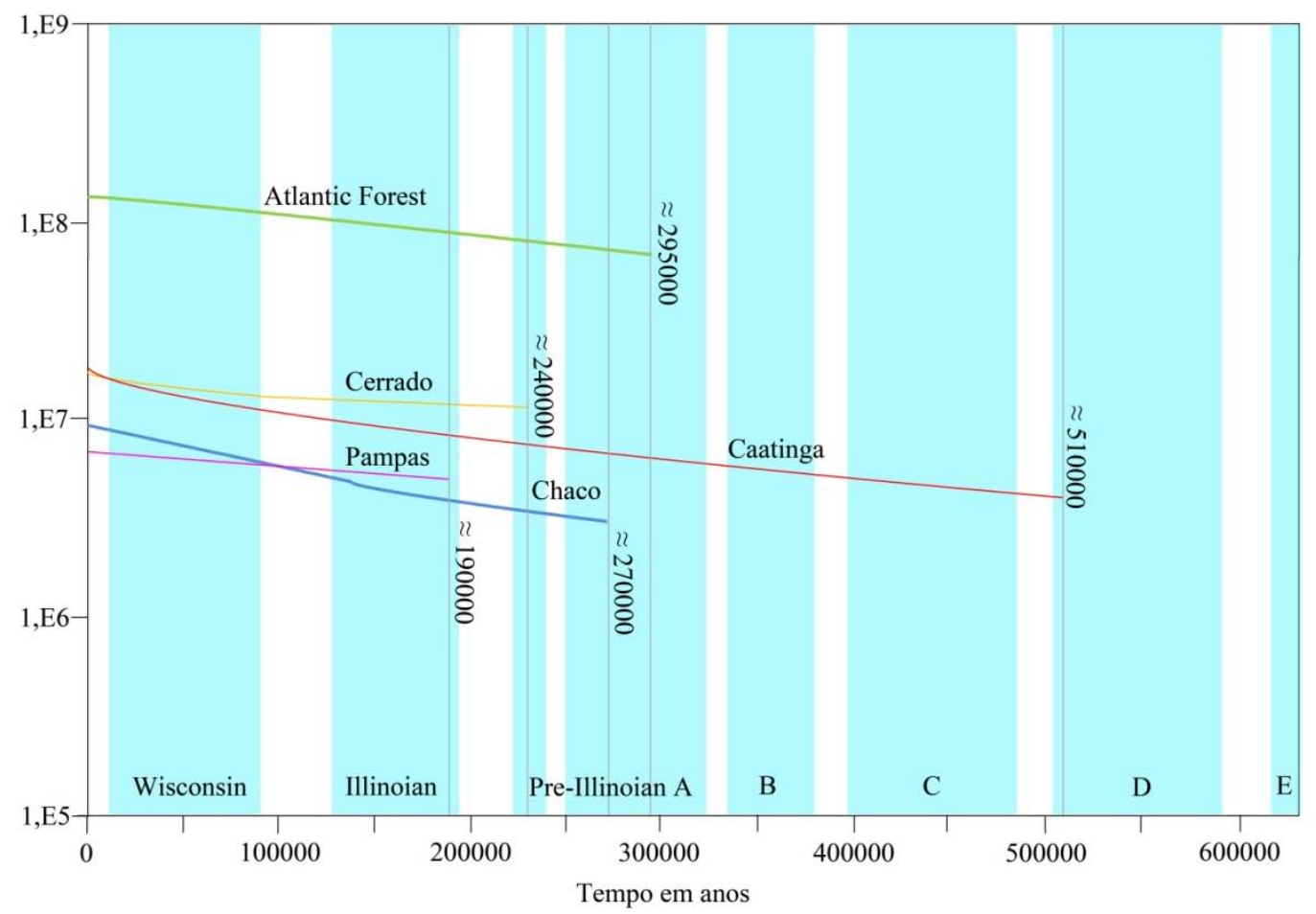

Figura 7. Estimativas dos tempos de expansão populacional geradas pela BSA. As colunas em azul representam eventos de resfriamento do planeta.

\subsubsection{Estimativas do sentido dos movimentos de expansão populacional.}

Utilizando o programa Migrate $\mathrm{N}$ foi estimada a quantidade e o sentido de migrantes entre grupos de amostras. A análise feita pelo programa Migrate $\mathrm{N}$ resultou em um padrão complexo de trocas de migrantes entre os domínios (Tabela 8). Foi encontrado que o domínio da Caatinga doa migrantes para a Floresta Altântica NE, 
recebendo migrantes do Cerrado e Floresta Atlântica NE. Já o domínio do Cerrado doa migrantes para a Caatinga, Floresta Atlântica NE e Pampas, recebendo migrantes da Floresta Atlântica e Floresta Atlântica NE. A Floresta Atlântica doa migrantes para o Cerrado e Chaco, recebendo migrantes somente do Chaco. O domínio dos Pampas somente doa migrantes para a Floresta Atlântica NE e recebe migrantes do Cerrado e do Chaco. Por fim, o domínio do Chaco doa migrantes para a Floresta Atlântica e Pampa, recebendo migrantes apenas da Floresta Atlântica.

Tabela 8. Resultados gerados pelo programa Migrate sem restrições para dispersão entre os domínios. Os números representam o número efetivo de migrantes (Nef) por geração e os domínios marcados com "+" representam domínios que estão recebendo migrantes.

\begin{tabular}{|l|l|l|l|l|l|l|}
\hline Domínio & Caatinga + & Cerrado+ & $\begin{array}{l}\text { Floresta } \\
\text { Atlântica } \\
\mathrm{NE}+\end{array}$ & $\begin{array}{l}\text { Floresta } \\
\text { Atlântica } \\
+\end{array}$ & $\begin{array}{l}\text { Pampas } \\
+\end{array}$ & Chaco+ $^{+}$ \\
\hline Caatinga & - & 0.000 & $2.10 \mathrm{e}^{3}$ & 0.000 & 0.000 & 0.000 \\
\hline Cerrado & 242.96 & - & 403.09 & 0.000 & $2.19 \mathrm{e}^{3}$ & 0.000 \\
\hline $\begin{array}{l}\text { Floresta } \\
\text { Atlântica NE }\end{array}$ & 173.11 & 207.51 & - & 0.000 & 0.000 & 0.000 \\
\hline $\begin{array}{l}\text { Floresta } \\
\text { Atlântica }\end{array}$ & 0.000 & 966.52 & 0.000 & - & 0.000 & $2.67 \mathrm{e}^{3}$ \\
\hline Pampas & 0.000 & 0.000 & 107.23 & 0.000 & - & 0.000 \\
\hline Chaco & 0.000 & 0.000 & 0.000 & $1.23 \mathrm{e}^{3}$ & $1.02 \mathrm{e}^{3}$ & - \\
\hline
\end{tabular}

\subsection{Resultados da modelagem de nicho ecológico}

Os modelos de nicho ecológico apresentaram resultados de AUC para o presente - 0,911, para o modelo passado CCSM - 0,912 e para o modelo passado MIROC - 0,900, indicando que o modelo testado representa melhor os resultados do que um modelo aleatório, o que é indicado por valores de AUC maiores que 0,5. Os mapas de predição gerados (Figuras 8, 9 e 10) foram ajustados para um limiar de 0,10, o qual engloba todos os pontos de presença amostrados. O mapa da distribuição atual gerado pelo programa MaxEnt é compatível com a distribuição prevista para a espécie $D$. buzzatii (Manfrin e Sene 2006), entretanto algumas áreas no Chile e Peru, representados no modelo, estão fora desta área. Ambos os modelos do presente e passado (CCSM e MIROC) resultaram em mapas de distribuição similares. Entretanto as projeções do passado, representando a última glaciação, apresentaram uma grande probabilidade de ocorrência da espécie ao longo das áreas costeiras do Uruguai e Brasil onde atualmente 
encontram-se cobertas pelo mar. Essa área de provável ocorrência ao longo da costa, segundo as projeções do modelo MIROC, abrange desde o centro oriental da Argentina e sul do Uruguai até o sul do estado da Bahia, no Brasil (Figura 10). O modelo CCSM abrange uma área menor, incluindo a costa brasileira do sul do estado do Rio Grande do Sul até o sul da Bahia e uma pequena região na Argentina, mas não engloba o Uruguai (Figura 9). As projeções do modelo CCSM também apresentam um corredor de probabilidade de ocorrência entre o Chaco, Peru e Equador, que apresenta-se muito fragmentado no mapa para o presente. As três projeções mostraram, em geral, grandes áreas de conectividade de $D$. buzzatii na América do Sul.

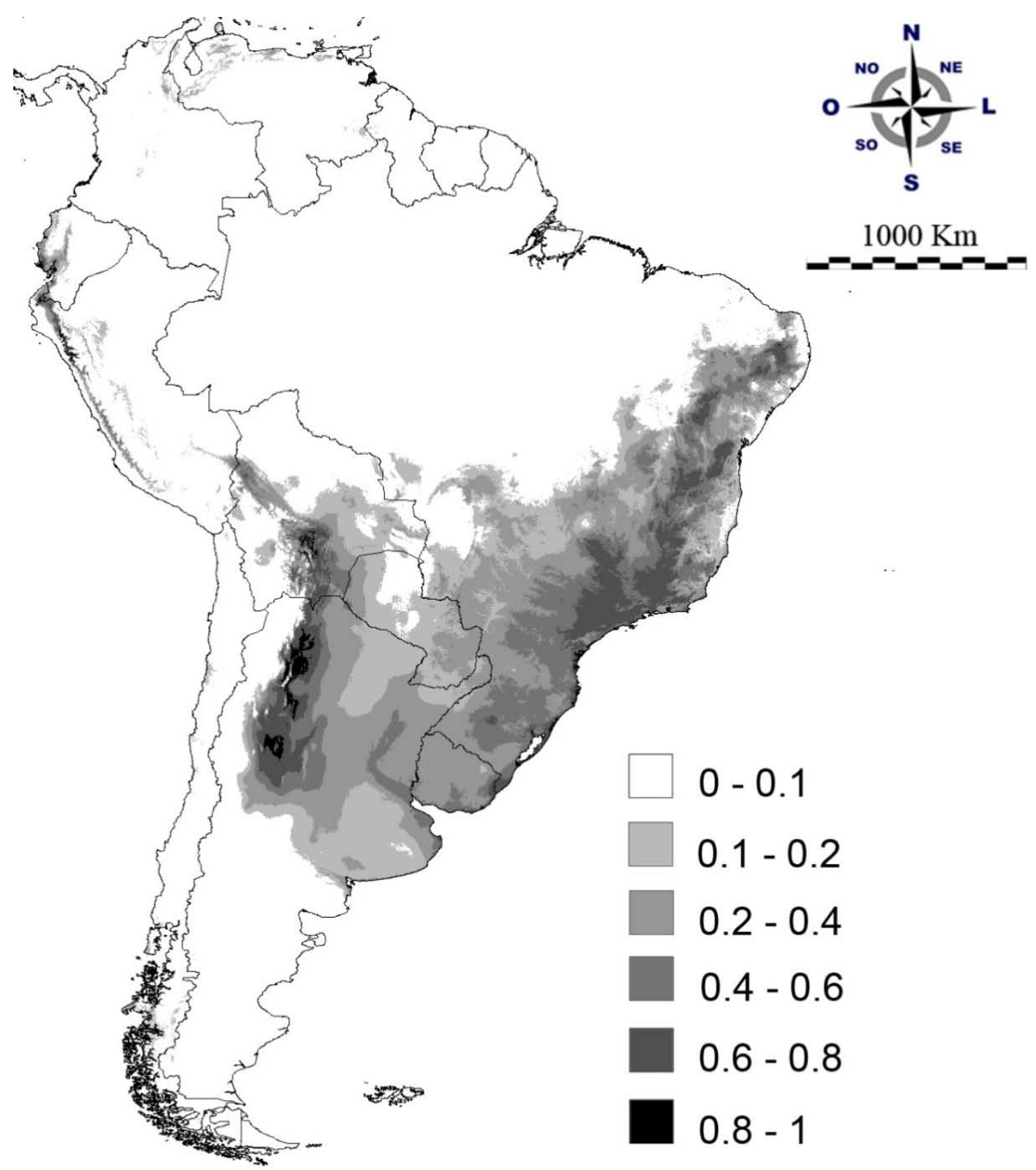

Figura 8. Modelo de probabilidade de presença da espécie $D$. buzzatii atual, gerada pelo programa MaxEnt. Os diferentes tons de cinza representam a probabilidade de existência da espécie. 


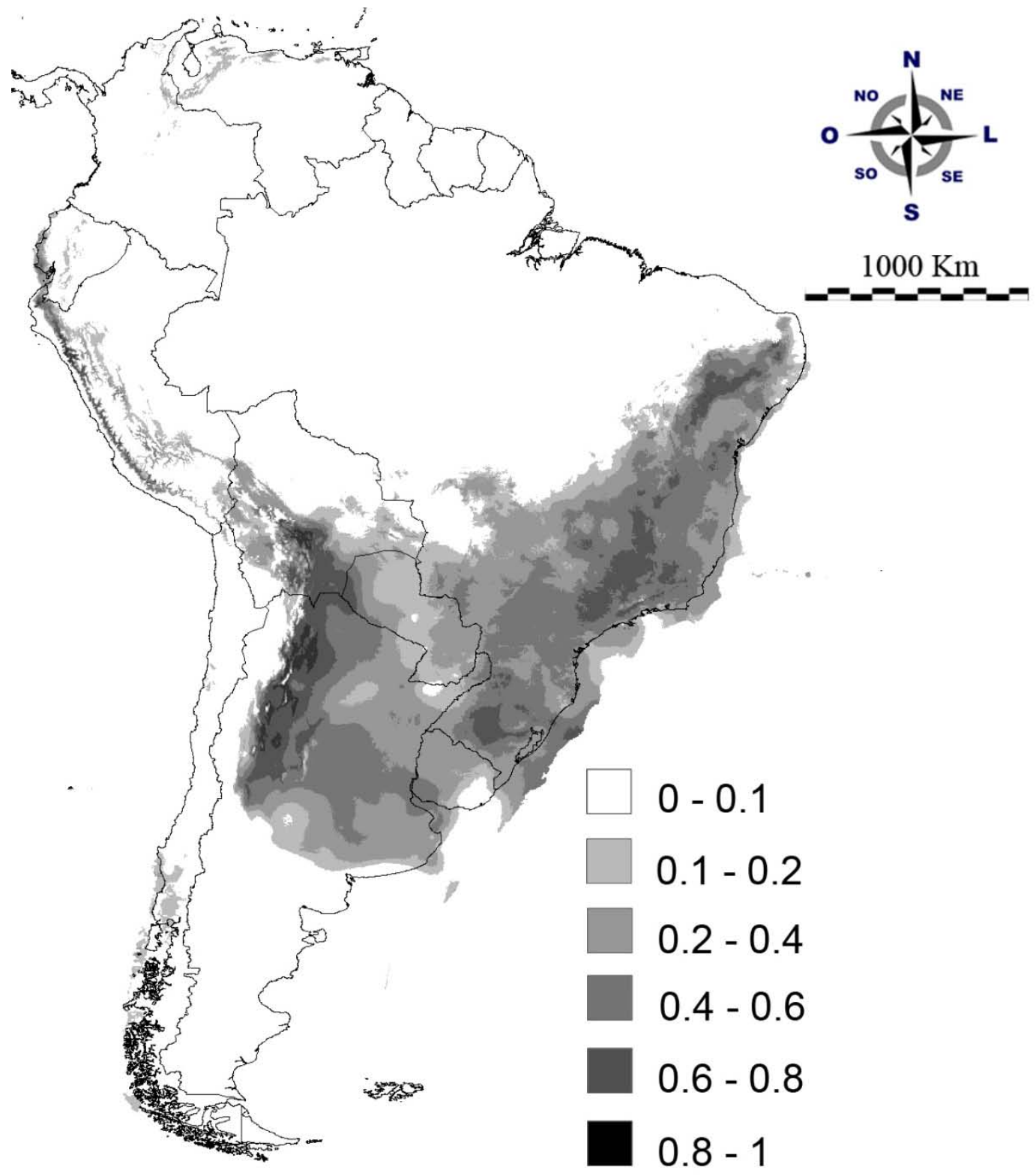

Figura 9. Modelo de probabilidade de presença da espécie $D$. buzzatii para o último período glacial (21000 anos atrás), gerada pelo programa MaxEnt, utilizando as projeções do CCSM. Os diferentes tons de cinza representam a probabilidade de existência da espécie. 


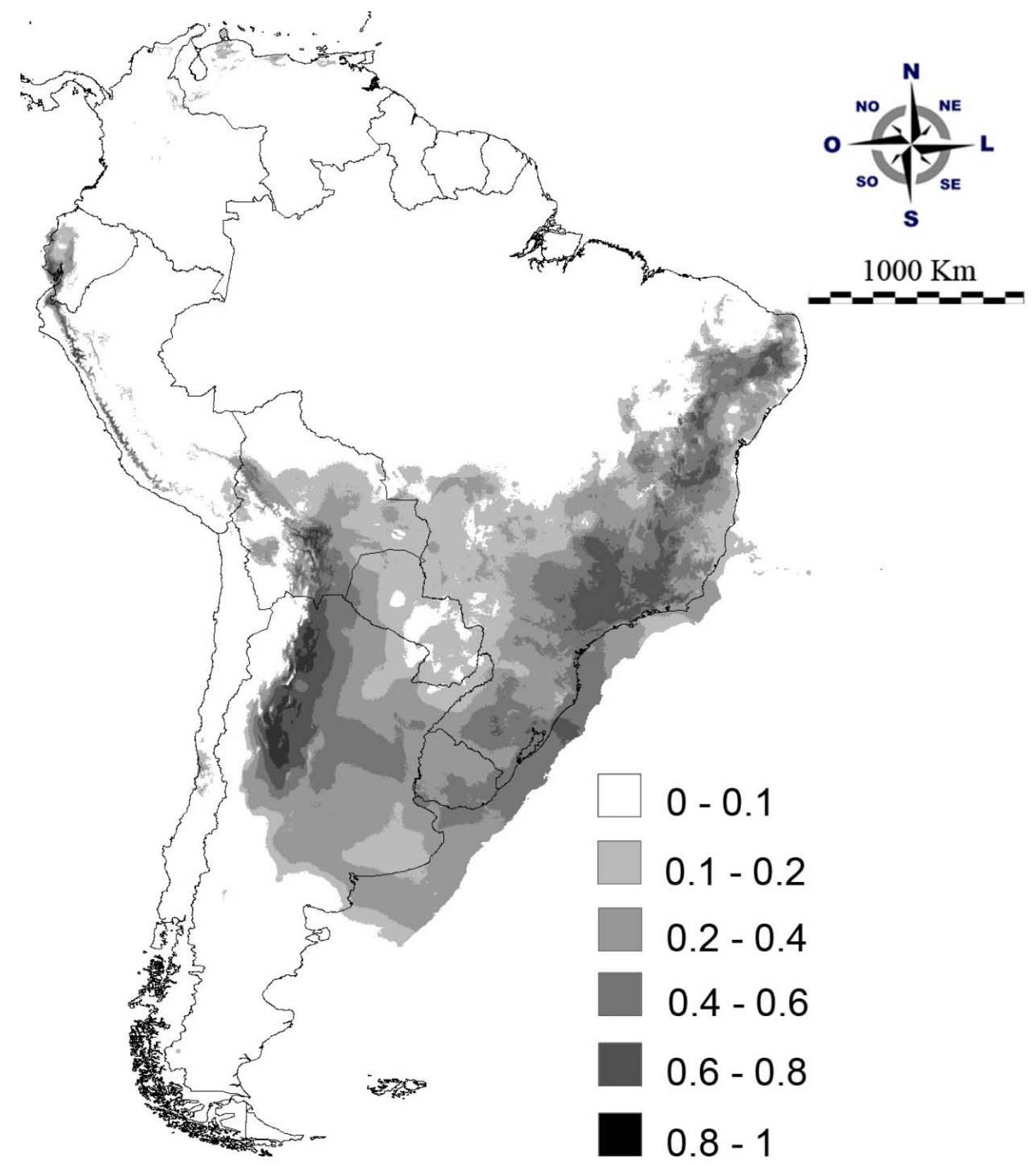

Figura 10. Modelo de probabilidade de presença da espécie $D$. buzzatii para o último período glacial (21000 anos atrás), gerada pelo programa MaxEnt, utilizando as projeções do MIROC. Os diferentes tons de cinza representam a probabilidade de existência da espécie. 


\section{Discussão}

\subsection{Variabilidade genética}

As análises de variabilidade do gene mitocondrial COI, obtidas nas populações de $D$. buzzatii apresentou valores em torno de 0,0022 ( $\pi$ ) e 0,6192 (h), sendo que a maior diversidade nucleotídica foi encontrada no domínio da Caatinga, o qual apresenta-se geneticamente estruturado. A diversidade nucleotídica nas populações de D. buzatii foi muito similar aos resultados encontrados para algumas espécies do “cluster” D. buzzatii como D. borborema e D. serido (Franco 2009) e também está em acordo com os resultados previamente descritos para a espécie (De Brito et al. 2002). Além disso, os resultados foram similares aos encontrados para outras espécies de Drosophilides (Hurtado et al. 2004) e outros insetos (Abellán et al. 2007; Gray et al. 2008). Entretanto os valores da diversidade nucleotídica de D. buzzatii são menores do que os encontrados para as espécies D. seriema, D. gouveai e D. antonietae (De Brito et al. 2002b; Franco 2009; Moraes et al. 2009). Baixos valores de diversidade nucleotídica são comumente encontrados em espécies com alta capacidade de dispersão, que sofreram processo de expansão populacional ou que sofreram algum tipo de seleção (Joseph et al. 2002; Santos et al. 2008). Comparativamente D. buzzatii apresentou valores de diversidade nucleotídica igual ou menor que $D$. serido, $D$. gouveai e $D$. antonietae espécies filogeneticamente próximas que apresentaram sinais de expansão poulacional (De Brito et al. 2002b; Franco 2009; Moraes et al. 2009).

Trabalhos anteriores demonstraram que a espécie $D$. buzzatii apresenta altos níveis de fluxo gênico (Thomas e Barker 1990; Rossi et al. 1996; De Brito et al. 2002a) e grande área de distribuição (Manfrin e Sene 2006), e existem apenas duas regiões na América do Sul onde a espécie apresenta altas densidades populacionais, a Caatinga no nordeste do Brasil (De Brito et al. 2002a) e o Chaco, na Bolívia e Argentina (Vilela et al. 1980). Essa alta densidade associada à diversidade de inversões cromossômicas foi utilizada como base para a proposta de que o “centro de origem” de $D$. buzzatii fosse o Chaco, pois não foram encontradas inversões cromossômicas na Caatinga (Carson e Wasserman 1965; Vilela, Sene, and Pereira 1980; Fontdevila 1989; Figueiredo e Sene 1992). Entretanto o trabalho de De Brito et al (2002a) levantou a hipótese de que o “centro de origem” da espécie deveria ser revisado. O conceito de centro de origem foi proposto originalmente por Darwin (1859) e tinha como idéia que o surgimento de uma 
espécie ocorreria em um determinado espaço geográfico e a partir deste ele se dispersaria por todo e qualquer lugar onde ela fosse capaz de sobreviver. Porém, esse conceito teleológico de “centro de origem” é muito criticado (Heads 2009), uma vez que outros eventos como vicariância podem ocorrer no processo de diferenciação de uma espécie. Segundo Gareth Nelson (em Heads 2009) todo biólogo é dispersalista a princípio, e somente quando estudam padrões biogeográficos eles desenvolvem interesse em vicariância. Ainda segundo Heads (2009) se a evolução desenvolve-se por vicariância não há a necessidade de se assumir uma postura teleológica ou simplesmente um ponto como “centro de origem”. Entretanto descartar completamente a dispersão populacional seria ingênuo, se considerarmos espécies com ampla distribuição geográfica e capacidade de colonização, como D. buzzatii.

Quando uma população passa por eventos de expansão populacional de área, freqüentemente só alguns dos haplótipos que estão presentes na distribuição original estarão na nova área. Desta maneira, haplótipos em populações em expansão são mais difundidos que os haplótipos que permaneceram na população fonte (Wilson et al. 1987), esse padrão foi confirmado por Templeton (1998). A expansão de área ocasiona uma sub-amostragem da diversidade da população fonte, consequentemente, a população em expansão apresenta uma diversidade nucleotídica menor do que a da população fonte, a menos que elas tenham sofrido uma rápida expansão no tamanho populacional (De Brito et al. 2002a). Se levarmos em conta que o "centro de origem" proposto para D. buzzatii é o domínio do Chaco (Carson e Wasserman 1965; Vilela et al. 1980; Fontdevila 1989; Figueiredo e Sene 1992) e que outros trabalhos apontam para eventos de expansão de área para a espécie (De Brito et al. 2002a, o presente trabalho) seria esperado, um polimorfismo genético afiliado e uma diminuição da diversidade nucleotídica quanto mais nos afastamos da população fonte, neste caso o Chaco, porém os resultados encontrados neste trabalho e em trabalhos anteriores (De Brito et al. 2002a; 2002b) não apontam para esse resultado. Os resultados encontrados neste trabalho mostram que a maior diversidade nucleotídica foi encontrada na Caatinga e que existe uma clara gradação decrescente no sentido Norte/Sul, através dos domínios fitogeográficos, além de dois clados aninhados formados basicamente por indivíduos da Caatinga. Resultado semelhante também foi encontrado por De Brito et al (2002), sendo que neste trabalho a NCPA indicou que a ocupação do Nordeste do Brasil não foi alcançada por uma expansão de área, nem recente nem antiga. Os resultados da "BSP” 
também indicaram que de fato o aumento no tamanho populacional ocorreu primeiramente nas populações do domínio da Caatinga e que a segunda expansão de área mais antiga gerada pela "Mismatch Distribution” foi o deste domínio (a mais antiga foi do domínio do Cerrado, adjacente à Caatinga).

A hipótese de um “centro de origem” para $D$. buzzatii é questionável, pois a definição de tal área é baseada em informações conflitantes (De Brito et al. 2002a, o presente trabalho) e este trabalho não disponibiliza de informações para comprovar onde $D$. buzzatii se diferenciou a partir de seu ancestral hipotético, nem mesmo qual processo, vicariância, dispersão ou outro foi o responsável pela diferenciação da espécie. Portanto, o que este trabalho discute são rotas de dispersão, e não onde foi o “centro de origem” de D. buzzatii, pois como discute Heads (Heads 2009) o próprio termo é questionável.

\subsection{Estruturação populacional, NCPA e teste de Mantel}

Apesar de trabalhos anteriores demonstrarem que $D$. buzzatii apresenta altos níveis de fluxo gênico (De Brito et al. 2002a), os resultados da AMOVA e Fst, sugerem que $D$. buzzatii apresenta-se estruturada geneticamente. Segundo nossos resultados o domínio da Caatinga apresenta-se geneticamente estruturado em relação aos demais domínios (Tabela 5), mas a estruturação entre os domínios também foi verificada (Tabela 4). A AMOVA foi significativa para todos os agrupamentos utilizados, sendo que $7,12 \%$ da variação foi encontrada entre os domínios, resultado de baixo fluxo gênico atual ou passado. Os testes de Mantel e NCPA sugerem que D. buzzatii apresenta isolamento por distância e alguma dispersão a longa distância em alguns dos clados analisados. Outras espécies do “cluster” D. buzzatii como D. gouveai (Moraes et al. 2009), D. seriema, D. serido, D. borborema (Franco 2009) e D. antonietae (De Brito et al. 2002b) além de um trabalho prévio com D. buzzatii (De Brito et al. 2002a) também sugeriram isolamento por distância. Estruturação nas populações do domínio da Caatinga também foi verificada por meio de marcadores morfológicos, como a forma e tamanho da asa e do aparelho reprodutor masculino, o edeago, em populações de $D$. buzzatii (Santos 2009; Santos e Manfrin 2010). Segundo esses autores, uma nítida separação entre as populações do domínio da Caatinga dos demais domínios analisados foi verificada. 
O domínio da Caatinga faz parte do grupo de formações vegetais adaptadas a climas secos que formam o chamado Arco-Pleistocênico, o qual abrange a Caatinga, Chaco, Cerrado, Núcleo Missiones (na bacia Paraná-Paraguai) e FTSS (Prado e Gibbs 1993, Prado 2000). Entretanto o trabalho de Prado (2000) sugere que o domínio da Caatinga tem origem de formações vegetais provenientes da América Central, enquanto que o domínio do Chaco apresenta origem subtropical, concluindo que esses dois domínios não possuem uma origem comum, mas uma nítida separação entre eles. O domínio da Caatinga também compartilha muitas espécies vegetais com a Floresta Atlântica NE e essa conexão entre essas duas regiões pode ser presumida a partir desse intercambio de espécies (Fiaschi e Pirani 2009). O domínio da Floresta Atlântica possuí uma separação histórica em duas região, uma ao norte do Rio Doce, formando a Floresta Atlântica NE que sofreu influência da vegetação do domínio da Caatinga e Floresta Amazônica e outro ao sul desta região (Fiaschi e Pirani 2009). A separação dos domínios da Caatinga e Floresta Atlântica NE das demais regiões ao sul pela composição florística pode estar sendo refletida pelos resultados da AMOVA e Fst, os quais também apresentam essa divisão, que pode ser verificada inclusive pelas análises morfométricas da forma e tamanho das asas e edeago que apresentam resultados muito semelhantes aos encontrados neste trabalho (Santos 2009; Santos e Manfrin 2010).

Apesar da nítida estruturação genética encontrada, os resultados da NCPA e teste de Mantel não descartam totalmente o fluxo gênico entre os domínios da Caatinga/Floresta Atlântica NE e os demais domínios, mas sugerem que o isolamento seja algo relacionado a distância entre as localidades. De fato, alguns autores propõem uma conexão das formações vegetais entre Caatinga/Floresta Atlântica NE o Cerrado, Floresta Atlântica e o Núcleo Missiones através de duas rotas: a rota sul e a rota norte (Prado e Gibbs 1993; Prado 2000). A rota norte ligou o domínio da Caatinga ao estado de Goiás, atravessado por uma estreita faixa, áreas de Cerrado atuais, seguindo os vales do Rio Grande, até a região do Distrito Federal, desviando ao norte até a região da Ilha do Bananal, em Tocantins, e ao sul até o Pantanal mato-grossense (Prado e Gibbs 1993; Prado 2000). A rota sul estendeu-se pelos vales do Rio São Francisco e Jequitinhonha, e ao sul ao longo do Rio das Velhas, até a região da cidade de Belo Horizonte e seguindo a leste até o estado do Rio de Janeiro, na região de Cabo Frio (Prado e Gibbs 1993; Prado 2000). Rotas similares ligando o domínio da Caatinga e o Centro-Oeste do Brasil e o estado do Rio de Janeiro também foram propostas por Ab’Saber (1977; 2003). 
Coletas na região dos estados do Espírito Santo e Rio de Janeiro em localidades com abundância de cactos onde a espécie $D$. serido está presente, não resultaram em indivíduos da espécie $D$. buzzatii. O fato de $D$. buzzatii não ser encontrada nessas regiões tem como uma possível explicação a composição climático/vegetacional, pois resultados de modelagem de nicho ecológico (Carnaval e Moritz 2008; Carnaval et al. 2009; Thomé et al. 2010; Werneck et al. 2010) tem demonstrado que essa região apresenta uma área de estabilidade a mudanças climáticas, formando o "Refúgio da Bahia” (Werneck et al. 2010, Figura 5, ver Figura 11 deste trabalho). Portanto, os resultados sugerem que se $D$. buzzatii conseguiu se deslocar utilizando a rota sul das FTSS, o caminho para o litoral do estado do Rio de Janeiro a partir da região da cidade de Belo Horizonte não foi seguido pela espécie. 

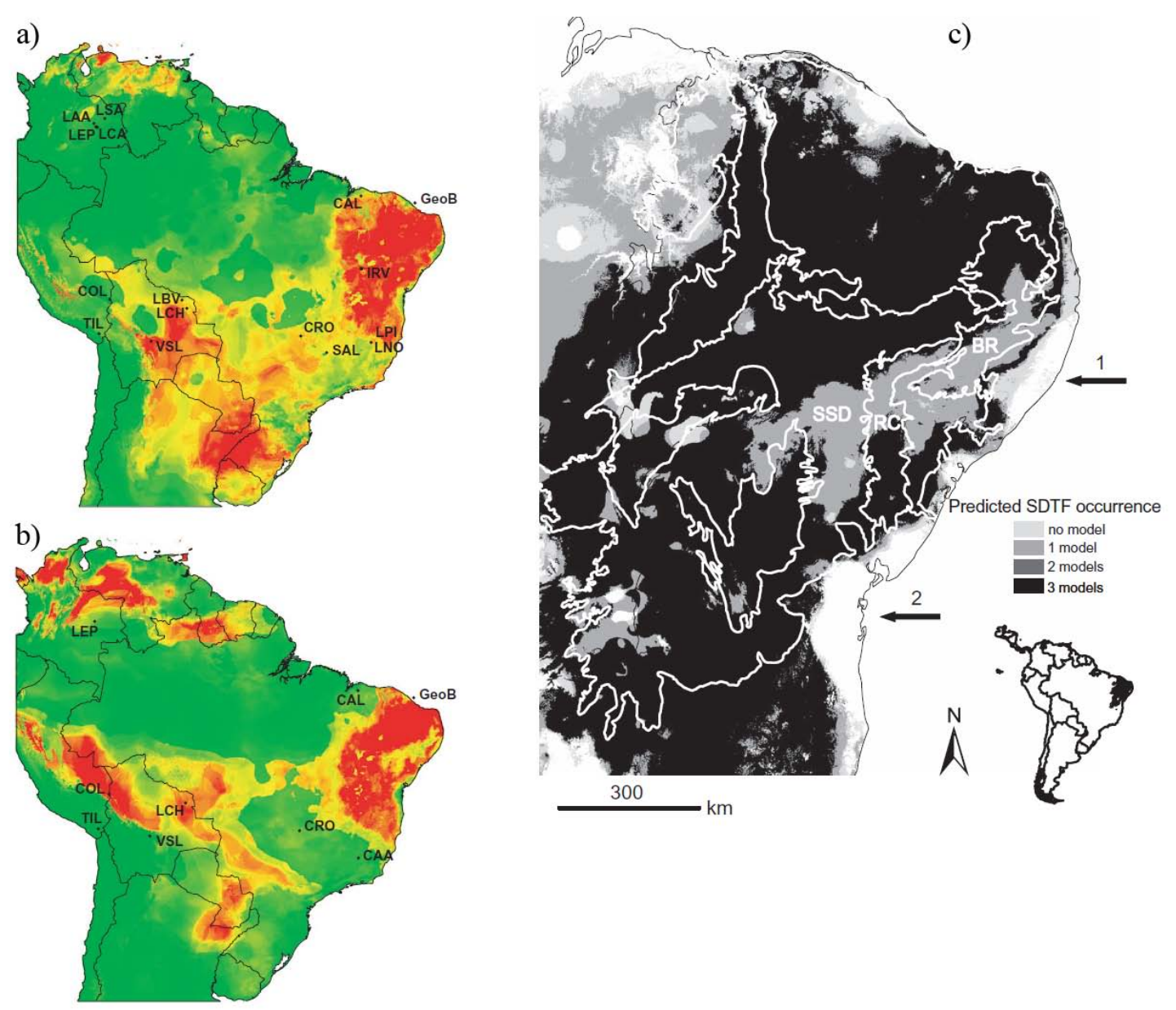

Figura 11. Paleomodelagem das FTSS obtidos por Werneck et al 2010 e agrupadas neste trabalho. A) predições da distribuição da FTSS durante o Holoceno - 6000 anos atrás, B) predições da distribuição da FTSS durante o último máximo glacial do Pleistoceno - 21000 anos atrás, sugerindo uma nítida separação do domínio da Caatinga, figura 5 de Werneck et al 2010, C) sobreposição dos modelos de predição da vegetação da Caatinga, em preto estão representadas áreas de estabilidade, em 1 "Refúgio de Pernambuco", em 2 "Refúgio da Bahia”, Figura 4 de Werneck et al 2010. Tons avermelhados indicam maior probabilidade de existência de FTSS.

\subsection{Modelagem de Nicho Ecológico e Paleomodelagem}

Os resultados da Modelagem de Nicho Ecológico e Paleomodelagem apresentam em sua maioria resultados condizentes com a área de ocorrência conhecida de D. buzzatii na América do Sul (ver Manfrin e Sene 2006 para área de distribuição da espécie). Além disso, esses resultados para a distribuição atual apresentaram algumas áreas ainda não amostradas como um corredor ligando o domínio do Chaco com o Peru e uma pequena área no Chile. Alguns relatos da ocorrência da espécie foram feitos no Peru (Ruiz, A. comunicação pessoal) e também no Chile em uma região próxima a área 
prevista neste trabalho (Brncic 1989). A espécie D. buzzatii está intimamente associada a cactos, plantas que dependem de climas secos para sua sobrevivência, portanto os resultados da Modelagem de Nicho Ecológico estão refletindo essas condições climáticas de clima mais seco no qual a espécie está associada.

As áreas de FTSS atuais sugeridas por Prado (2000) são parcialmente semelhantes às áreas de distribuição prevista para $D$. buzzatii, nos resultados da modelagem de nicho ecológico com valores de “Threshold” superior a 0,5 (Figura 12). Essa distribuição de $D$. buzzatii também é semelhante em parte, aos resultados de Werneck et al (2010) (Figura 11, b), o que reflete a associação entre essa espécie e as regiões de clima seco da América do Sul.

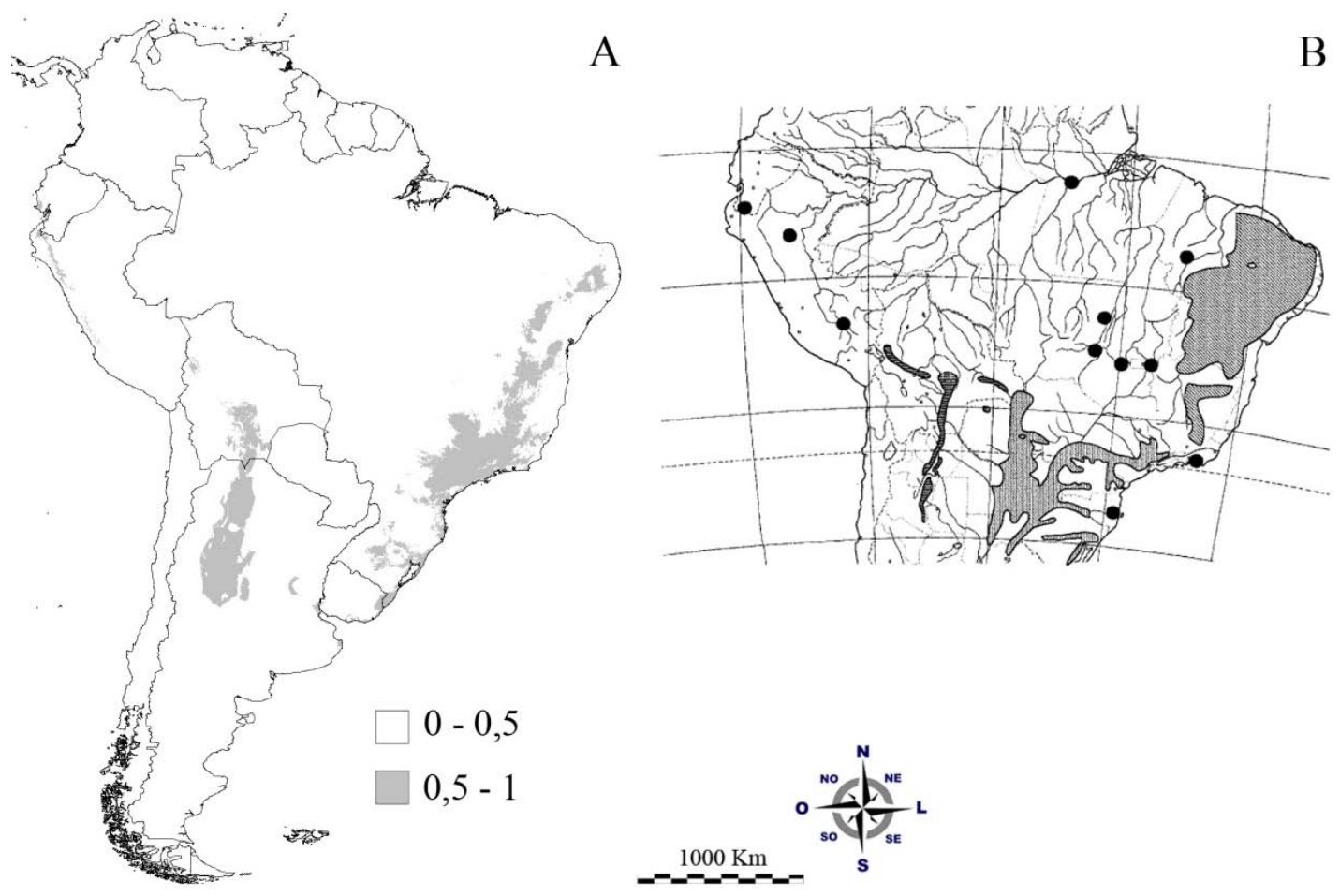

Figura 12. A - Probabilidade de distribuição de $D$. buzzatii com valores de Threshold superior a 0,5 no presente. B - Distribuição da FTSS produzido por Prado (2000).

Já os resultados de Paleomodelagem para o último período glacial estão em acordo com o esperado para uma espécie associada a climas secos, uma vez que durante esse período, a diminuição da umidade favoreceu a expansão das espécies associadas a climas mais secos. Os mapas de Paleomodelagem apresentaram áreas de probabilidade 
de distribuição relativamente maiores do que os do presente, como são esperados nessas condições climáticas. A diferença entre os resultados dos modelos CCSM e MIROC reside, principalmente, em uma área onde hoje se encontra coberta pelo mar, na costa do Brasil, e por uma área na região do Paraguai. Essas diferenças são os resultados das diferenças nas estimativas das condições bioclimáticas adotadas por cada modelo, entretanto a semelhança entre ambos é significativa (Figuras 9 e 10).

\subsection{Movimentos históricos.}

Os resultados dos testes de neutralidade e da "Mismatch Distribution" revelaram que as populações de $D$. buzzatii nos domínios da Caatinga, Cerrado e Chaco sofreram eventos de expansão populacional. Resultados semelhantes também foram encontrados para outras espécies do “cluster” D. buzzatii, como D. gouveai, D. serido, D. seriema e D. borborema, na Caatinga (Franco 2009; Moraes et al. 2009). No caso de D. gouveai duas rotas migratórias foram propostas: a rota norte-sul, onde populações do nordeste, no domínio da Caatinga, passaram por um movimento de expansão populacional em direção sul por topos de montanhas a leste do vale do Rio Paraná (grupo G1) e a rota para o sul, via topos de morro a oeste do vale do Rio Paraná no Brasil Central (grupo G2) (Moraes et al. 2009). Para as espécies D. serido, D. serima e D. borborema foram sugeridos movimentos de expansão populacional a partir de uma região próxima à Chapada Diamantina no domínio da Caatinga (Franco 2009) sendo que para $D$. serido, uma rota migratória partindo do interior da Bahia até o litoral do estado de Santa Catarina foi previamente descrita (Morales 2005).

Eventos de expansão populacional podem ocorrer quando as condições ambientais são favoráveis ao desenvolvimento e reprodução da espécie, como abundância de alimento, local para procriação, abrigo e redução dos competidores. Apesar do movimento de expansão de $D$. buzzatii ter sido detectado pelos testes de neutralidade apenas nos domínios da Caatinga, Cerrado e Chaco, outros testes indicaram expansão populacional também no domínio dos Pampas, com exceção da Floresta Atlântica. A associação entre a estimativa dos tempos dos movimentos de expansão e o sentido da troca de migrantes indicou que esses eventos ocorreram durante períodos de glaciação do Pleistoceno. Esses períodos são marcados pela diminuição da água na forma líquida disponível no planeta que fica retida nos pólos na forma de gelo, diminuindo a umidade e favorecendo a expansão de vegetação de climas secos e fauna 
associada. Os domínios da Caatinga, Cerrado e Chaco apresentam-se intimamente associados a condições de clima com baixa umidade (Fiaschi e Pirani 2009), desta maneira, os resultados dos testes de neutralidade associados à "BSP" e "Mismatch distribution" estão refletindo a expansão de $D$. buzzatii juntamente com seus domínios associados a climas secos nessas condições favoráveis.

A fisionomia dos domínios do Cerrado e Caatinga como conhecemos hoje, formou-se em torno de 25 - 28 milhões de anos atrás e o domínio do Chaco entre 2 - 3 milhões de anos atrás, devido em parte ao soerguimento dos Andes (Gottsberger e Silberbauer-Gottsberger 2006; Zanella 2010). Esses domínios sofreram movimentos de retração e expansão de sua área devido a mudanças climáticas ao longo do Pleistoceno, deixando regiões relíquias ao longo de sua distribuição formando o que alguns autores chamaram de Arco-Pleistocênico (Prado e Gibbs 1993; Prado 2000). Esses movimentos possibilitaram a migração de espécies vegetais e animais associados a climas secos, em rotas que hoje não são claramente reconhecidas. Esses movimentos de retração e expansão da vegetação, cíclicos, durante períodos glaciais e interglaciais podem ter respondido de forma similar ao longo dessas mudanças, entretanto em outras áreas isso pode não ser verdadeiro. Como trabalhos de paleomodelagem delineando a paisagem fitogeográfica de períodos pré-Wiscosin (há mais de 21.000 anos) são escassos, utilizamos o último período glacial como base para a geração dos mapas de probabilidade de existência da espécie $D$. buzzatii em um período glacial e em contrapartida o modelo atual para períodos interglaciais e esses resultados foram extrapolados para períodos anteriores

\subsubsection{Movimentos a partir do domínio da Caatinga}

Os resultados combinados das análises demonstraram que o movimento de expansão populacional sofrido por $D$. buzzatii teve início há 510.000 anos com o aumento do tamanho populacional da espécie no domínio da Caatinga, como sugere a “BSP” e a "Mismatch distribution” (Figuras 13 e 14). A associação desta informação com os resultados de paleomodelagem indicou que as populações de $D$. buzzatii se deslocaram para o sul da Paraíba em áreas de alta probabilidade de ocorrência, seguindo provavelmente a dispersão de suas espécies de plantas hospedeiras (Figura 14). Dessa região a espécie continuou seu movimento de expansão até o interior do estado da Bahia e divide-se em dois caminhos, um a leste deslocando-se até a região da cidade de 
Salvador e outro seguindo para o interior do domínio da Floresta Atlântica ao sul (como sugerido pelo resultado do programa Migrate). Ao chegar à região da cidade de Salvador, a espécie parece ter cessado o movimento migratório. O litoral brasileiro é marcado por dunas e formações rochosas, ambientes favoráveis ao estabelecimento de muitas das espécies hospedeiras de $D$. buzzatii e de fato, essas espécies de cactos são encontradas ao longo de praticamente toda a costa (Taylor e Zappi, 2004). Entretanto $D$. buzzatii não é encontrada no litoral dos estados do Espírito Santo e Rio de Janeiro, apesar da existência de cactos e das espécies cactófilas $D$. serido e $D$. meridionalis nessas regiões. Uma possível explicação é que essa região apresenta grande estabilidade climática e vegetacional, formando o que alguns autores sugerem ser o "Refúgio da Bahia” (Carnaval e Moritz 2008; Carnaval et al. 2009; Thomé et al. 2010; Werneck et al. 2010), uma região de alta umidade e precipitação. De fato o limite da distribuição de D. buzzatii no litoral do estado da Bahia parece ser a região da cidade de Salvador. Esse fato pode ser comprovado pela observação dos mapas de modelagem de nicho ecológico e paleomodelagem (Figuras 8, 9 e 10) os quais apresentam áreas de baixa probabilidade de existência de $D$. buzzatii nessas regiões. Coletas realizadas nestas regiões obtiveram sucesso na captura das espécies cactófilas $D$. serido e $D$. meridionalis, mas não $D$. buzzatii. O movimento para o sul parece ter seguido a expansão das FTSS seguindo a rota sul de Prado e Gibbs (1993). Outras espécies como D. serido e D. gouveai parecem ter compartilhado essa mesma rota com $D$. buzzatii, ou parte dela, porém em períodos de tempo diferentes (Morales 2005; Franco 2009; Moraes et al. 2009). Entretanto o fato da espécie $D$. buzzatii não ser encontrada na região de Cabo Frio, local em que a rota sul chega a um ponto final (Prado e Gibbs 1993) pode ser explicado por duas hipóteses: i) D. buzzatii conseguiu se deslocar até a região e não se estabeleceu, fato comprovado por coletas em regiões próximas ou ii) em algum ponto entre a região de Minas Gerais e Cabo Frio o deslocamento tomou um desvio para o sul, como sugerem os mapas de paleomodelagem (Figuras 9 e 10). 

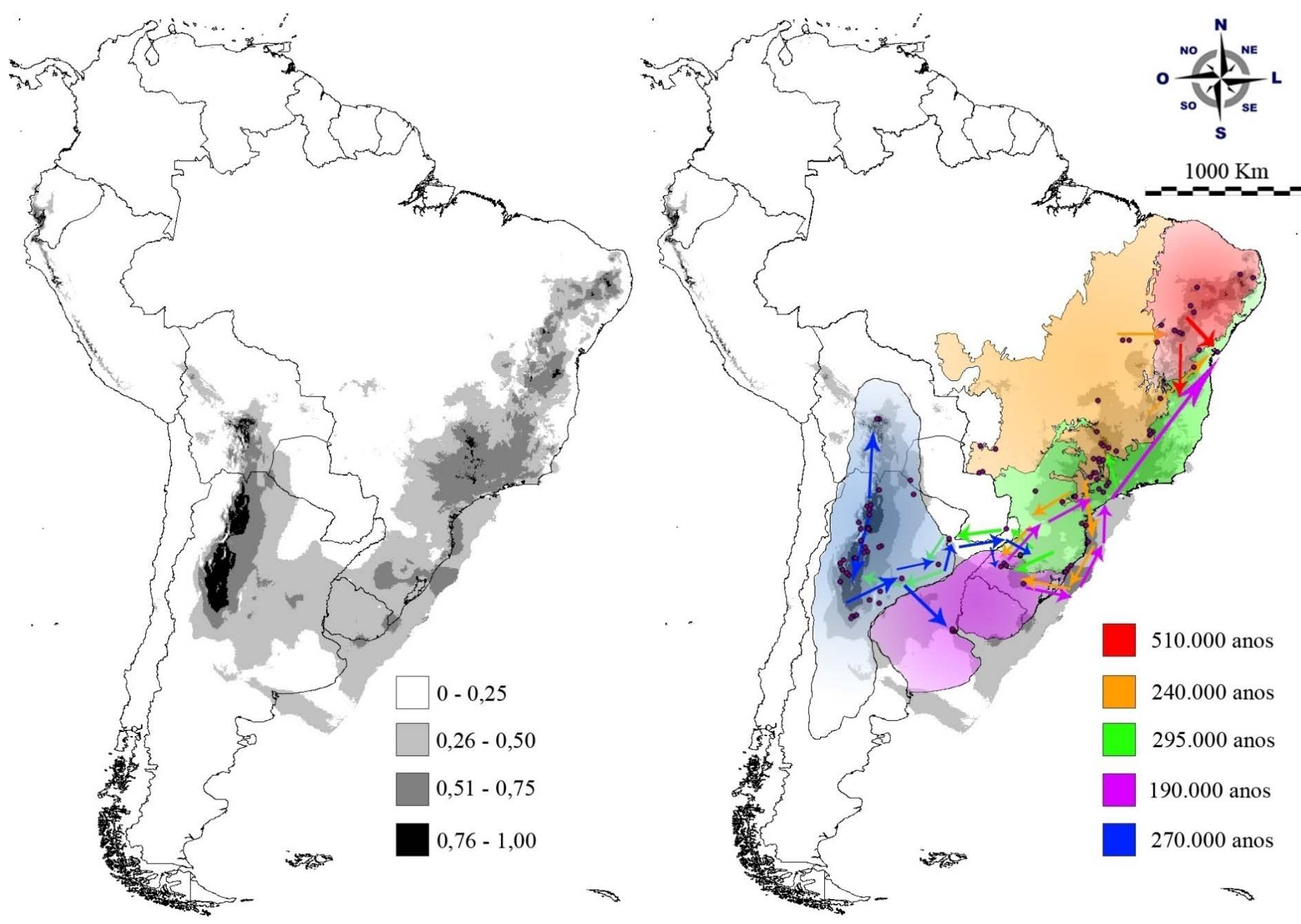

Figura 13. Associação dos resultados de modelagem de nicho ecológico baseado no modelo MIROC para 21.000 anos atrás, durante o último máximo glacial, com os resultados filogeográficos. As cores representam os domínios fitogeográficos e as setas coloridas o sentido dos movimentos. O tempo para cada movimento foi estimado utilizando a BSP. Círculos em roxo representam os pontos de coleta utilizados na paleomodelagem (Apêndice 1). 
O trabalho de Gibbard e Kohen (2008) sugere que entre 500.000 e 600.000 anos atrás ocorreu um período de resfriamento das condições climáticas do planeta conhecido como Pré-Ilinoian D (Figura 7). Esse período de resfriamento pode ter favorecido a dispersão e conexão das espécies hospedeiras ao longo da rota sul de Prado e Gibbs (1993) que foi seguida por D. buzzatii. Assim, uma hipótese para explicar esse movimento seria que as populações de D. buzzatii estariam acompanhando a expansão da vegetação associada a climas secos como as FTSS pelo interior do estado de Minas Gerais, contornando o "Refúgio da Bahia” principalmente em afloramentos rochosos ou relíquias de formações de cactos, encontrado na FTSS (Zanella 2010). Esse movimento pela rota sul, das populações de $D$. buzzatii, do domínio da Caatinga, ao longo da Floresta Atlântica enfrentou pelo menos três períodos interglaciais, o que pode ter forçado a espécie a ficar restrita em formações vegetais isoladas. Resultados de expansão populacional também foram verificados em outras espécies do Cluster $D$. buzzatii, como D. gouveai (Moraes et al. 2009), D. serido e D. seriema (Franco 2009). A espécie D. gouveai é comumente encontrada em topos de morros associadas a espécies de cactos na vegetação rupestre. Esta espécie apresentou duas rotas de migração para o sul, uma a leste do vale do rio Paraná, com tempo de expansão populacional aproximado de 463.000 anos atrás (intervalo de confiança de 221.000 a 701.000) e outra rota mais recente a oeste do vale do rio Paraná, há 175.000 anos (intervalo de confiança de 0 a 313.000) (Moraes et al. 2009). O padrão de expansão populacional com recorrentes contrações e expansões podem ser verificados pelo padrão multimodal encontrado na "Mismatch Distribution” nas populações do domínio da Floresta Atlântica, o qual também pode ser interpretado como uma população em equilíbrio, pois em condições de equilíbrio são esperadas variações no tamanho populacional (Roger e Harpending 1992). O resultado da rede de haplótipos (Figura 4) também sugere uma conexão entre o domínio da Caatinga e a Floresta Atlântica, pois no clado 2-2 e 2-3 há uma predominância de haplótipos pertencentes à região da Caatinga e estão presentes os haplótipos 27 e 34, pertencentes à região da Floresta Atlântica. Outro dado interessante é que o haplótipo 34 da Ilha de Santa Catarina, na região da cidade de Florianópolis é geneticamente muito similar aos haplótipos do interior da Bahia, diferindo apenas por um passo mutacional. Resultado semelhante também foi 
encontrado para a espécie D. serido nas mesmas regiões (Morales 2005), corroborando essa hipótese de migração da Caatinga para a Floresta Atlântica.
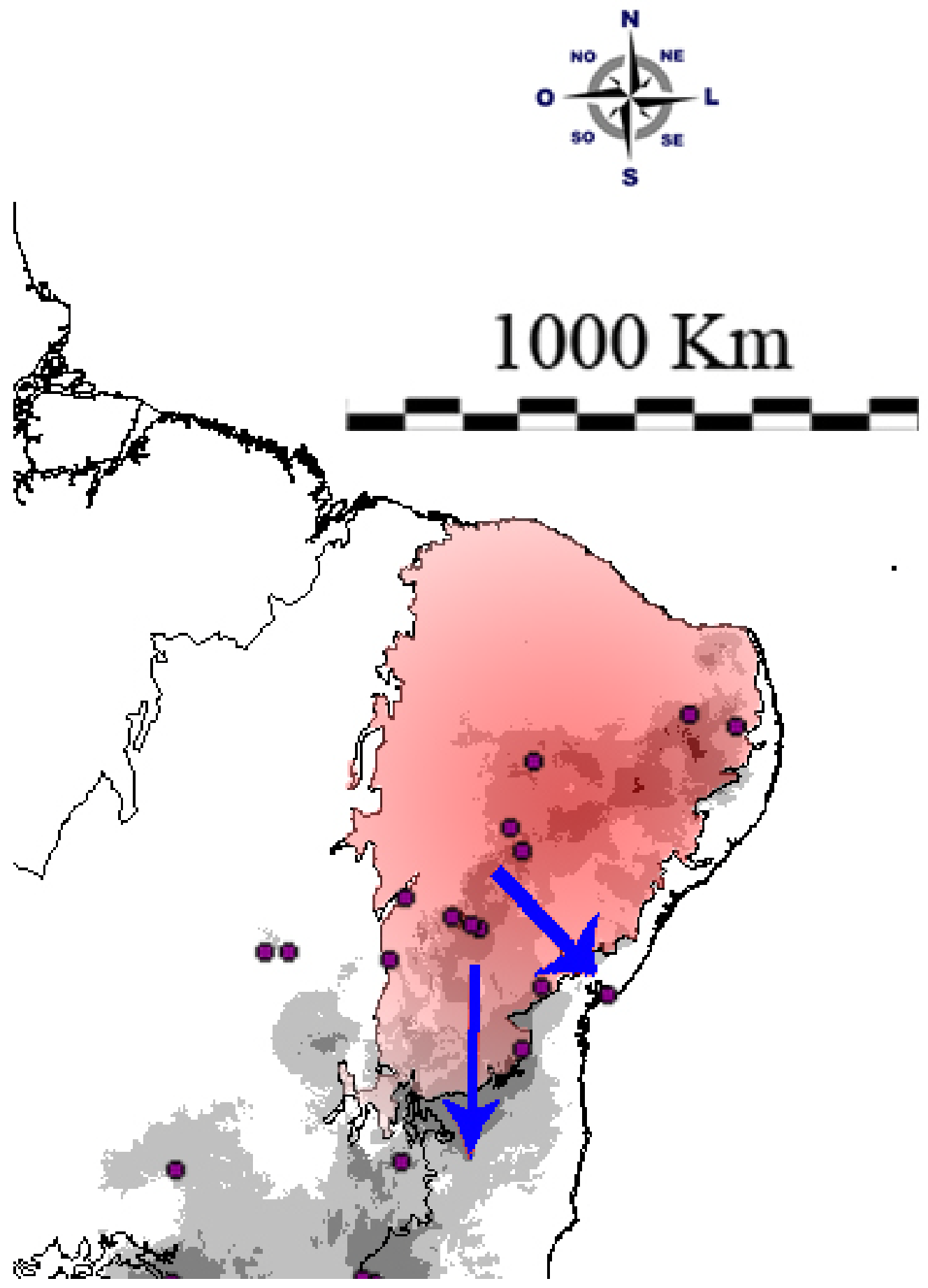

Figura 14. Rotas migratórias no domínio da Caatinga, resultado da comparação entre as análises filogeográficas e de paleomodelagem para o último período Glacial a 21.000, segundo o modelo MIROC. A gradação em tons de cinza indica a probabilidade de ocorrência da espécie $D$. buzzatii. Círculos em roxo representam os pontos de coleta utilizados na paleomodelagem (Apêndice 1). 


\subsubsection{Movimentos a partir do domínio da Floresta Atlântica}

Os resultados da “BSP” e da “Mismatch Distribution” apontaram para um crescimento populacional há aproximadamente 295.000 anos, durante o período glacial do Pré-Ilinoian A, na população de D. buzzatii do domínio da Floresta Atlântica. Esse movimento ocorreu em dois sentidos: em uma rota noroeste, com a migração de populações do domínio da Floresta Atlântica para o Cerrado e uma rota oeste do domínio da Floresta Atlântica para o Chaco (Figura 15).

A rota noroeste da Floresta Atlântica para o Cerrado pode ter ocorrido em períodos de condições climáticas favoráveis a expansão da FTSS adaptada a climas secos, invadindo o domínio da Floresta Atlântica e possibilitando a dispersão de $D$. buzzatii para o Cerrado, principalmente no Estado de São Paulo e norte do Paraná, onde a divisão entre os dois domínios é mais sutil. Se as condições climáticas desse período quando ocorreu a expansão populacional de D. buzzatii no domínio da Floresta Atlântica, foram semelhantes às encontradas para a última glaciação, então podemos dizer que pode ter se formado um corredor de dispersão ao longo do estado de São Paulo e dali se espalhado pelo domínio do Cerrado, em áreas de FTSS (Figura 11, b).

O segundo movimento migratório ocorreu entre o domínio da Floresta Atlântica e o Chaco, na Argentina, a rota oeste, como sugere os resultados da "BSP” e do programa Migrate. Segundo os resultados de paleomodelagem de Werneck et al. (2010) e deste trabalho, há uma junção de FTSS entre o domínio da Floresta Atlântica, Cerrado e do chamado Núcleo Missiones (Morrone 2006), assim, D. buzzatii deslocouse para o leste seguindo a Bacia dos rios Paraná-Paraguai, até o núcleo de FTSS de Missiones e de lá para o domínio do Chaco. Essa também é uma rota histórica de dispersão de $D$. antonietae em que essa espécie a partir do estado de São Paulo colonizou a norte do estado do Paraná e Rio Grande do Sul (De Brito et al. 2002b). A espécie D. antonietae apresenta associação com a espécie de cacto Cereus hildmaniannus, que ocorre em matas mesofílicas de galeria, ao longo dos rios da bacia do Paraná-Paraguai. Essa hipótese de corredores de migração para $D$. antonietae foi embasada no gradiente morfológico/genético encontrado para a espécie ao longo do leito dos rios dessa região (Mateus e Sene 2007). A espécie D. buzzatii também utiliza o cacto Cereus hildmaniannus como recurso, principalmente no interior do estado do Rio Grande do Sul, no Brasil, mais especificamente da localidade de Guaritas (Ruiz et al. 
2000). Portanto $D$. buzzatii pode ter utilizado rotas de migração semelhantes às de $D$. antonietae e continuado movendo-se até o domínio do Chaco.

A chegada e colonização de $D$. buzzatii no domínio do Chaco parece ter propiciado um aumento rápido no tamanho populacional desta espécie, como sugere os resultados da "BSP". Trabalhos anteriores relataram a alta densidade de D. buzzatii no domínio do Chaco (Carson e Wasserman 1965; Vilela et al. 1980), podendo esse aumento ser o resultado de condições ambientais e ecológicas favoráveis encontradas neste domínio. Trabalhos de associação entre $D$. buzzatii e suas plantas hospedeiras têm demonstrado que há grande variação na viabilidade, tempo de desenvolvimento e tamanho do tórax de $D$. buzzatii dependendo do cacto hospedeiro e de qual inversão cromossômica no cromossomo 2 a espécie carrega (Iriarte e Hasson 2000). O resultado do trabalho de Iriarte e Hasson (2000) demonstrou que indivíduos de D. buzzatii utilizando meio de cultura contendo o cacto Trichocereus terschekii (uma espécie de cacto colunar muito comum na Argentina) e o arranjo cromossômico $2_{\text {st }}$ apresentaram uma viabilidade significativamente maior do que nos outros tratamentos, já os arranjos cromossômicos $2_{\mathrm{jq}}{ }^{7}$ aumentaram a viabilidade em meios de cultura contendo Opuntia fícus-indica e Opuntia vulgaris, concluindo que a interação cacto/cariótipo é determinante do valor adaptativo na espécie (Iriarte e Hasson 2000). Outro exemplo é a espécie $D$. mojavensis que apresenta polimorfismo de inversões em dois cromossomos apenas em populações que utilizam o cacto agria (Machaerocereus gummosusna) na região de Baja na Califórnia (Powell 1997). Portanto, como características importantes para a sobrevivência de $D$. buzzatii como a viabilidade e taxa de ovoposição, são dependentes em parte, dos arranjos cromossômicos presentes nas populações (Iriarte e Hasson 2000; Fanara e Hasson 2001), é plausível supor que tenha ocorrido seleção natural forte nas populações de D. buzzatii ao encontrarem novos recursos no domínio do Chaco e que esse processo de seleção favoreceu o aumento da freqüência de inversões cromossômicas favoráveis à sobrevivência da espécie neste domínio. O reflexo desse processo foi verificado na grande quantidade de inversões cromossômicas encontrada no domínio do Chaco em trabalhos anteriores (Vilela et al. 1980; Fontdevila 1989; Figueiredo e Sene 1992), entretanto, devido a falta de ferramentas estatísticas e de análises moleculares mais atuais, os resultados de alguns desses autores levou a hipótese de que o “Centro de Origem” de $D$. buzzatii é o domínio do Chaco, porém, os resultados encontrados neste trabalho e em outros trabalhos anteriores (De Brito et al. 2002a) não 
estão em acordo com essa hipótese como proposto por (De Brito et al. 2002) a hipótese de que o “Centro de Origem” é o domínio do Chaco deve ser revista.

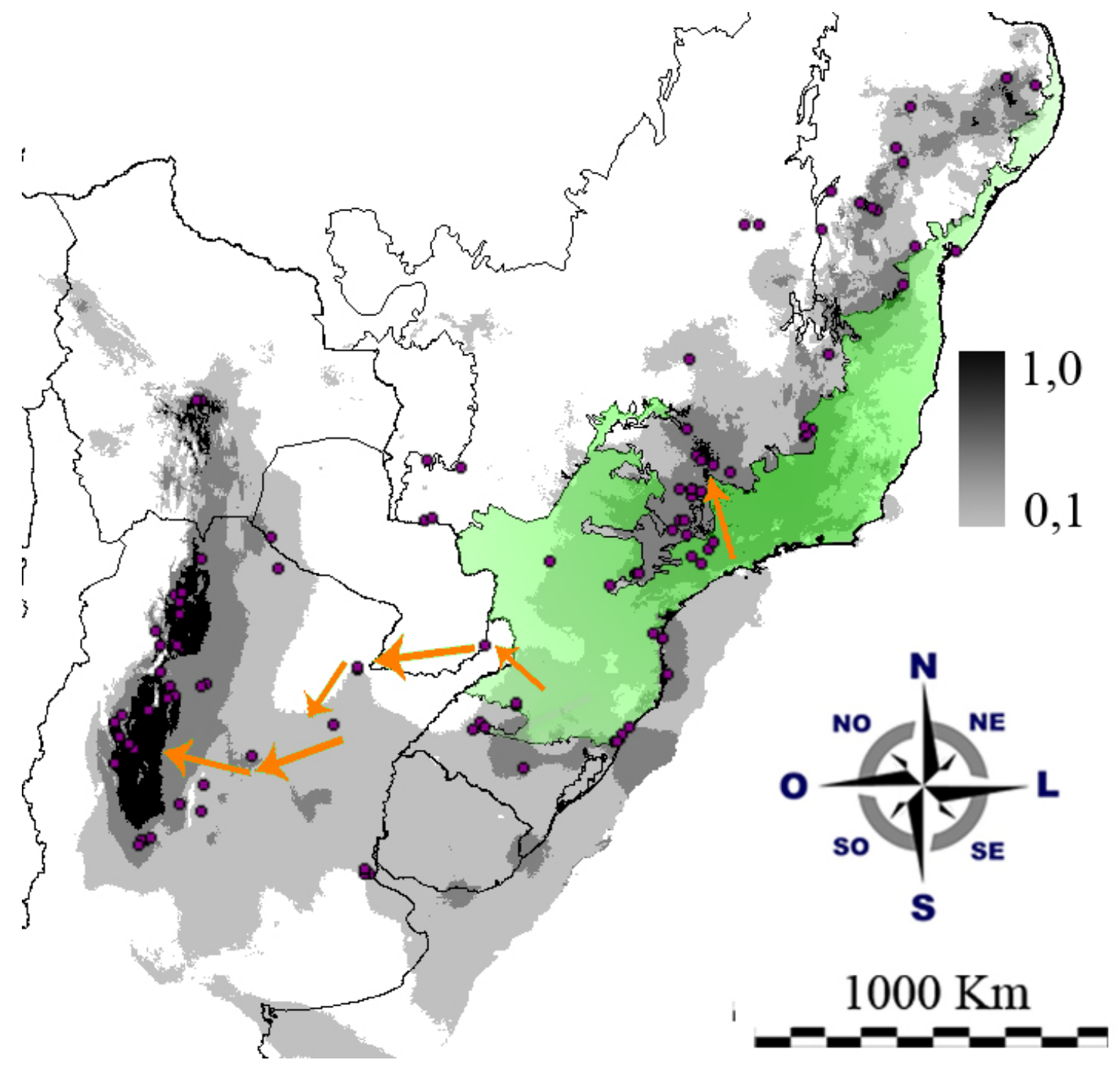

Figura 15. Rotas migratórias no domínio da Floresta Atlântica, resultado da comparação entre as análises filogeográficas e de paleomodelagem para o último período Glacial a 21.000, segundo o modelo MIROC. A gradação em tons de cinza indica a probabilidade de ocorrência da espécie $D$. buzzatii. Círculos em roxo representam os pontos de coleta utilizados na paleomodelagem (Apêndice 1).

\subsubsection{Movimentos a partir do domínio do Chaco}

Os resultados da "BSP”, "Mismatch Distribution” e Migrate sugerem que há 270.000 anos duas rotas de dispersão deixam a região do Chaco: uma rota leste, contrária a rota oeste que partiu da Floresta Atlântica para o Chaco e a rota sudeste que seguiu em direção a região do domínio dos Pampas (Figura 16). 
A rota leste provavelmente seguiu rotas similares as utilizadas na colonização do Chaco por populações provenientes do domínio da Floresta Atlântica, como discutido anteriormente.

Já o movimento migratório das populações do domínio do Chaco para o domínio dos Pampas, pela rota sudeste, parece ter seguido áreas de afloramento rochoso ou áreas de concentração de cactáceas entre esses domínios adjacentes. Áreas de probabilidade moderada de presença $(0,4$ - 0,6) de $D$. buzzatii nos mapas de paleomodelagem (Figuras 9 e 10) demonstram que a espécie pode ter se deslocado pela Argentina até o Uruguai e o estado do Rio Grande do Sul ou seguido uma rota alternativa do primeiro movimento descrito, deslocando-se para o sul da Bacia do Paraná-Paraguai e migrando para o domínio dos Pampas. Trabalhos relatando rotas de dispersão semelhantes para insetos são escassos. Foi encontrada uma variação da diversidade nucleotídica em um gradiente norte/sul na região do domínio do Chaco em lhamas (Lama guanicoe) (Marín et al. 2008) o que indica movimentos em direção norte/sul com melhoria das condições de vida de espécies adaptadas a climas mais secos e $D$. buzzatii pode ter se deslocado neste sentido no domínio do Chaco em um primeiro momento. Porém, trabalhos com mamíferos comumente encontrados em regiões de clima seco, como roedores Tuco-Tuco (Ctenomys australis) demonstraram movimentos de expansão populacional a leste em dunas na Argentina (Mora et al. 2006; GonzálezIttig et al. 2007). O movimento de expansão a leste da Argentina sugere que áreas de vegetação de clima seco poderiam estar se deslocando neste sentido, devido a mudanças climáticas e $D$. buzzatii pode ter utilizado essa expansão a leste para dispersar. Migrações durante o Pleistoceno em tatus (Chaetophractus villosus) que migraram do domínio dos Pampas para a Patagônia argentina (Poljak et al.), também seguindo uma rota norte/sul, indicando que existiu uma tendência de algumas espécies de moverem-se para o sul. Se isso for verdadeiro também para $D$. buzzatii, então ela teria seguido um movimento em direção sul/sudeste no domínio do Chaco e depois leste/sudeste em direção aos Pampas. Os resultados da NCPA confirmam em parte os resultados dessas rotas migratórias, pois, foi encontrado no clado 1-2, formado apenas por amostras do Chaco, fluxo gênico e dispersão, mas com alguma dispersão a longa distância (Tabela 3). Trabalhos de filogeografia utilizando outras espécies, principalmente com as cactáceas hospedeiras de $D$. buzzatii podem confirmar a existência dessa rota migratória entre os domínios do Chaco e Pampas. 


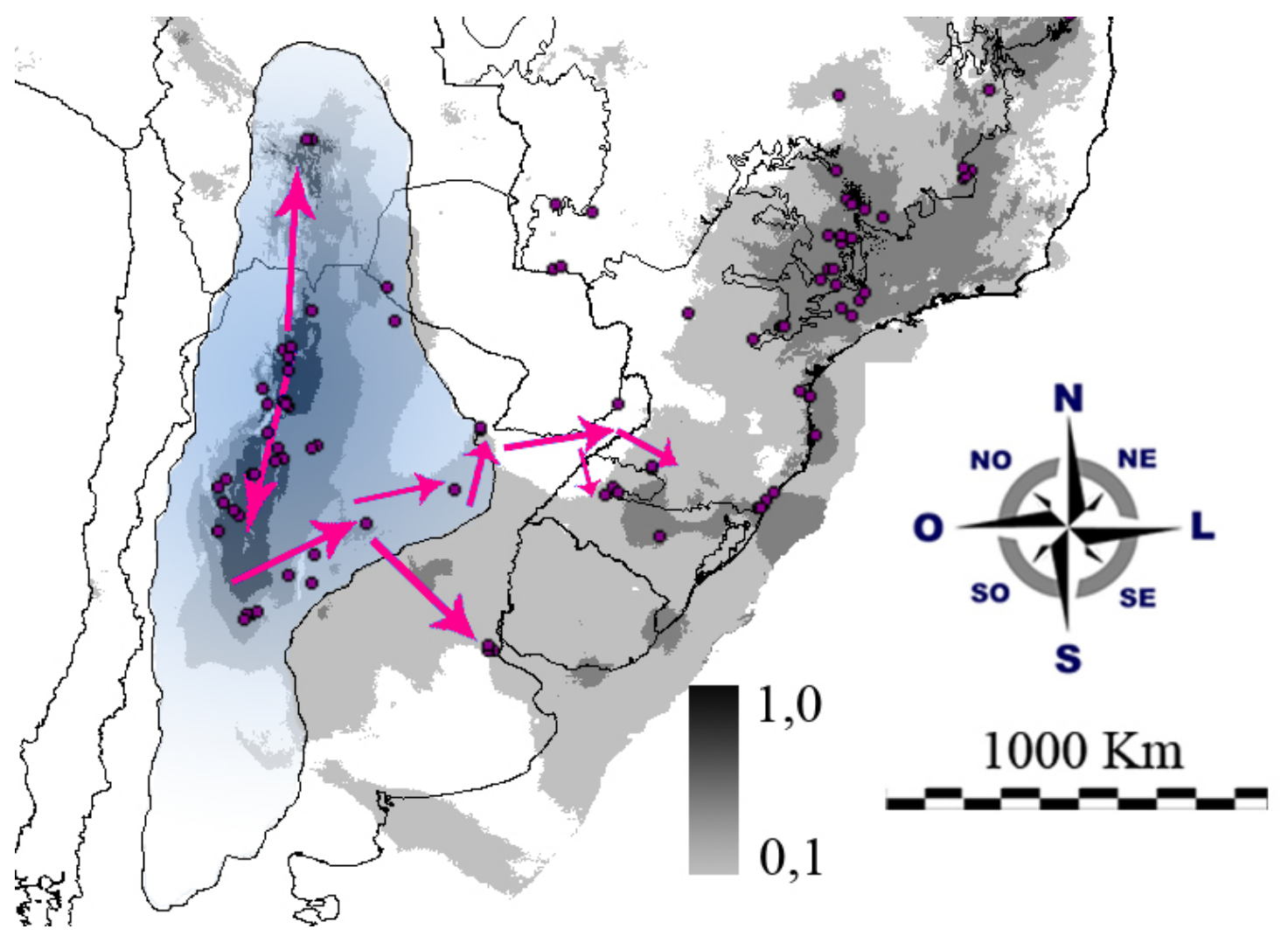

Figura 16. Rotas migratórias no domínio do Chaco, resultado da comparação entre as análises filogeográficas e de paleomodelagem para o último período Glacial a 21.000, segundo o modelo MIROC. A gradação em tons de cinza indica a probabilidade de ocorrência da espécie $D$. buzzatii. Círculos em roxo representam os pontos de coleta utilizados na paleomodelagem (Apêndice 1).

\subsubsection{Movimentos a partir do domínio do Cerrado}

Os resultados da AMOVA e Fst indicaram que o domínio da Caatinga apresenta-se fortemente estruturado geneticamente resultando em baixo fluxo gênico entre este domínio e seus adjacentes, entretanto essa estruturação não isolou completamente o domínio da Caatinga como sugerem os resultados da "BSP", "Mismatch Distribution”, testes de neutralidade e "Migrate”, discutidos anteriormente. Os resultados combinados destes testes sugerem que há 240.000 anos, as populações de D. buzzatii do domínio do Cerrado passaram por um evento de expansão populacional, em quatro rotas: uma rota norte, trocando migrantes com as populações do domínio da Caatinga, uma rota nordeste, doando migrantes para o domínio da Floresta Atlântica NE, uma rota sudeste e uma rota sul, ambas trocando migrantes com o domínio dos Pampas (Figura 17).

A rota norte parece ter seguido um caminho inverso ao movimento do grupo G2 de D. gouveai (Moraes et al. 2009). Segundo esse autor, o grupo G2 de D. gouveae 
passou por um processo de expansão populacional que teve início na região do domínio da Caatinga há 175.000 anos e seguiu em sentido sul para o Brasil central através dos topos de morro do domínio do Cerrado, a oeste do vale do Rio Paraná, por caminhos semelhantes à rota norte proposta por Prado e Gibbs (1993) e Prado (2000). Se levarmos em consideração que o tempo de expansão utilizado por Moraes et al. (2009), para o grupo G2, possui um intervalo de confiança que chega a um valor máximo 313.000 anos (Moraes et al. 2009, tabela 2), podemos considerar que durante esse movimento de expansão do grupo G2 de D. gouveai existia um corredor ligando os domínios da Caatinga e Cerrado e que esse pode ter sido usado concomitantemente pelas duas espécies em ambos os sentidos, ou via Cerrado - Caatinga ou Caatinga - Cerrado.

A rota nordeste pode a princípio ter seguido o mesmo caminho utilizado pelas populações da rota norte, mas tomado um sentido leste até regiões próximas a cidade de Salvador por meio dos corredores de vegetação compartilhados entre a Caatinga e a Floresta Atlântica NE, como discutido anteriormente.

As populações de $D$. buzzatii ainda tomaram uma rota no sentido sul trocando migrantes com o domínio dos Pampas, como sugerem os resultados da "BSP” e “Migrate”. Essa rota parece ter seguido os mesmos caminhos utilizados pela espécie $D$. antonietae, seguindo a expansão do cacto C. hildmanianus pela bacia do ParanáParaguai, como discutido anteriormente. Entretanto, ao invés de D. buzzatii seguir para oeste até o domínio do Chaco, essa rota desviou para o sul até o domínio dos Pampas.

Os resultados de paleomodelagem em conjunto com a "BSP” e "Migrate" sugerem que $D$. buzzatii pode ter tomado outro caminho até o domínio dos Pampas. Essa rota sudeste teria seguido a expansão do Cerrado em uma estreita faixa próxima ao litoral do estado de São Paulo, que pode ter se expandido até chegar à região costeira. Durante a última Glaciação do Pleistoceno, o nível do mar apresentava-se cerca de 120 metros mais baixo do que os níveis atuais (Clapperton 1993) resultando em um alargamento da região costeira atual do Brasil. Se a diminuição dos níveis do mar seguiu esse padrão em outros períodos glaciais, então podemos supor que a costa brasileira aumentou de tamanho, propiciando um novo ambiente para a colonização das plantas hospedeiras e $D$. buzzatii. A espécie $D$. buzzatii é encontrada muitas vezes associada a cactos presentes nas regiões costeiras, sobre rochas ou na areia das dunas nas praias brasileiras (Manfrin e Sene 2006). Com o aumento das plantas hospedeiras 
dessa região, poderia ter se formado uma conexão entre o domínio do Cerrado e o litoral ligando este domínio aos Pampas, como sugerem os mapas de paleomodelagem (Figura 9, 10 e 17).

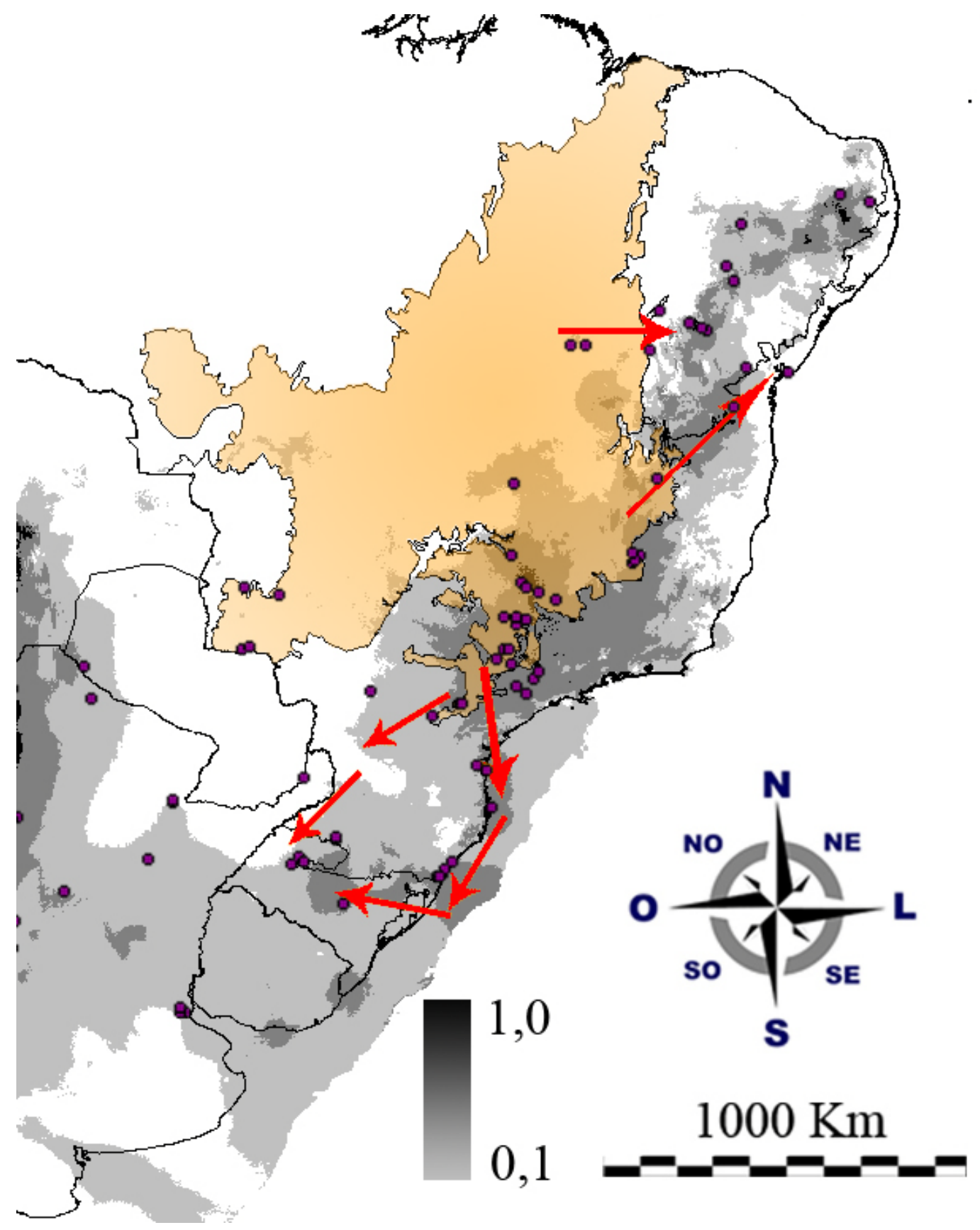

Figura 17. Rotas migratórias no domínio do Cerrado, resultado da comparação entre as análises filogeográficas e de paleomodelagem para o último período Glacial a 21.000, segundo o modelo MIROC. A gradação em tons de cinza indica a probabilidade de ocorrência da espécie $D$. buzzatii. Círculos em roxo representam os pontos de coleta utilizados na paleomodelagem (Apêndice 1). 


\subsubsection{Movimentos a partir do domínio dos Pampas}

Os resultados da "BSP" demonstraram que o domínio dos Pampas sofreu uma expansão populacional há 190.000 anos (Figura 18). Esse período corresponde ao início da Glaciação do Ilinoian (Figura 7). O resultado do programa Migrate N indicou que a espécie $D$. buzzatii doa migrantes para o domínio da Floresta Atlântica NE, separado dos Pampas pelo domínio da Floresta Atlântica. A partir desses resultados duas rotas para a expansão das populações do domínio dos Pampas podem ser propostas: uma rota norte-ocidental, seguindo do domínio da Floresta Atlântica, pela bacia do ParanáParaguai até a Floresta Atlântica NE e uma rota norte-oriental, via costa pelos estados do Rio Grande do Sul, Santa Catarina, Paraná e São Paulo e seguindo pelo interior até a Floresta Atlântica NE.

A rota norte-ocidental pode ter seguido o caminho inverso à rota utilizada pelas populações do Cerrado que migraram até o domínio dos Pampas, utilizando em parte a espécie de cactos C. hildmanianus até o domínio do Cerrado, na região da cidade de Belo Horizonte e utilizando a rota sul de expansão da FTSS proposta por Prado e Gibbs (1993) e Prado (200) para se deslocarem até o domínio da Caatinga e de lá utilizando os caminhos usados para a troca de espécies vegetais, atingindo a Floresta Atlântica NE, como discutido anteriormente (Figura 18).

Já a rota norte-oriental seguiu, em parte, o caminho inverso das populações que migraram do domínio do Cerrado para os Pampas, utilizando a rota via costa até o domínio do Cerrado, onde podem ter utilizado o mesmo caminho pela rota sul de expansão da FTSS até a Floresta Atlântica NE, como discutido anteriormente (Figura 18).

Essa troca entre o domínio dos Pampas e Floresta Atlântica NE pode ser em parte confirmada pela presença do haplótipo 34, pertencente à ilha de Santa Catarina, na região da cidade de Florianópolis e que apresenta muita semelhança com os haplótipos comumente encontrados na Caatinga, como pode ser observado na rede de haplótipos (Clado 2-3, Figura 7). Análise de populações de $D$. buzzatii e cactáceas em ilhas costeiras ao longo do litoral dos estados do Rio Grande do Sul, Santa Catarina e São Paulo podem confirmar a existência desse movimento migratório. 


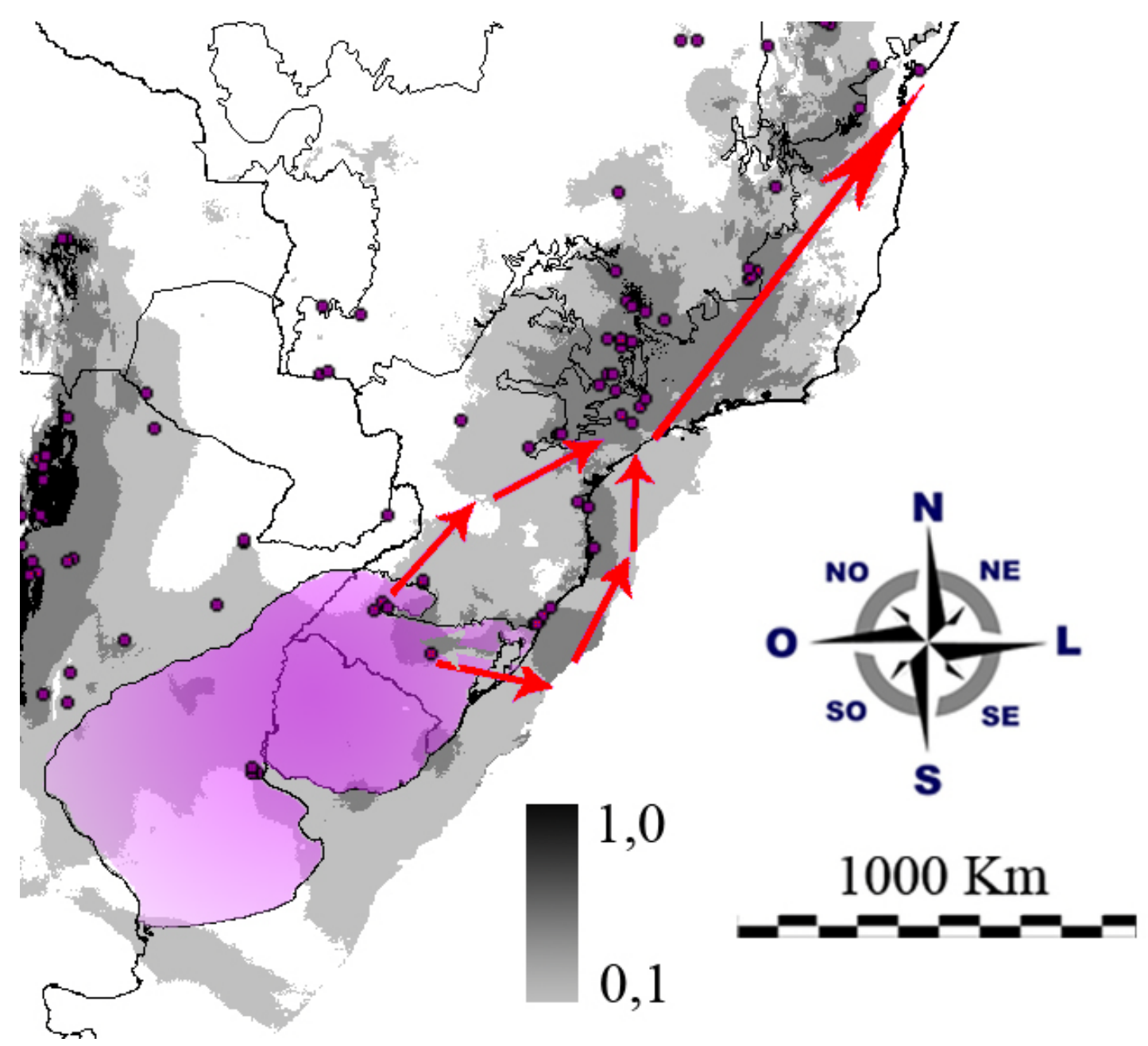

Figura 18. Rotas migratórias no domínio dos Pampas, resultado da comparação entre as análises filogeográficas e de paleomodelagem para o último período Glacial a 21000, segundo o modelo MIROC. A gradação em tons de cinza indica a probabilidade de ocorrência da espécie $D$. buzzatii. Círculos em roxo representam os pontos de coleta utilizados na paleomodelagem (Apêndice 1).

A idéia de dispersão ativa e natural da espécie $D$. buzzatii no Continente Americano já havia sido proposta por De Brito et al (2002a), ao estimaram um evento de expansão populacional de D. buzzatii no sudeste do Brasil entre 105.000 e 154.000 anos. Esses valores diferem dos obtidos neste trabalho provavelmente devido ao método utilizado, pois De Brito et al (2002a) utilizaram a abordagem de Rogers e Harpending (1992) gerada pela "Mismatch Distribution” e a escolha de agrupar as amostras por estado, um agrupamento político que nem sempre é respeitado pelas espécies. Já o presente trabalho agrupou as amostras por domínios fitogeográficos, uma representação mais natural da distribuição das espécies e utilizou uma abordagem mais atual para estimar o tempo dos eventos de expansão populacional (BSP). Os resultados obtidos no presente trabalho sugerem eventos de expansão populacional préHoloceno corroborando a idéia da presença de D. buzzatii no Continente Americano antes da presença do ser humano, como proposto no trabalho de De Brito et al (2002a). 


\section{Conclusões}

A partir dos resultados obtidos neste trabalho podemos concluir que:

- Os valores da diversidade nucleotídica por domínio apresentam uma clina norte/sul bem delimitada o que pode ser o resultado de um movimento migratório neste sentido com perda de variabilidade devido à sub-amostragem decorrente deste movimento.

- O domínio da Caatinga apresenta-se fortemente estruturado geneticamente, apesar de a divisão por domínio fitogeográfico também apresentar certo grau de estruturação.

- A espécie D. buzzatii apresenta movimentos de dispersão a longa distância, mas também apresenta isolamento por distância, devido em parte a barreiras climáticas e geográficas que dificultam o deslocamento da espécie em algumas regiões.

- Foram encontrados fortes indícios de expansão populacional nos domínios da Caatinga, Cerrado e Chaco, regiões geralmente associadas a condições ambientais com baixa umidade.

- Esses movimentos de expansão populacional tiveram início há aproximadamente 500.000 - 600.000 anos durante períodos de glaciação e diminuição da umidade relativa do planeta e que cada domínio respondeu diferentemente a cada um desses períodos.

- Em geral, os movimentos migratórios mais antigos ocorreram em um sentido Norte/Sul, mas movimentos mais recentes parecem ter seguido várias rotas de dispersão, em geral acompanhando os movimentos de expansão da vegetação adaptada a climas secos e das espécies de plantas hospedeiras, utilizadas por $D$. buzzatii.

- Os resultados obtidos no presente trabalho não confirmam a hipótese de que o “centro de origem” da espécie $D$. buzzatii é o Chaco e concordam com hipóteses anteriores de revisão dessa hipótese do “centro de origem”.

- Os tempos de expansão obtidos são concordantes com eventos propostos por diversas espécies proximamente relacionadas e confirmam a hipótese de dispersão ativa e natural da espécie $D$. buzzatii.

- A partir dos mapas de modelagem de nicho ecológico e paleomodelagem foram sugeridas áreas de provável distribuição da espécie na América do Sul e coletas em áreas ainda não amostradas podem confirmar os resultados obtidos no presente trabalho. 


\section{Referências Bibliográficas}

Ab'Sáber, A. 2003. Os domínios de natureza no Brasil: potencialidades paisagísticas: Atelié editorial.

Ab’Saber, A. 1977. Espaços ocupados pela expansão dos climas secos na América do Sul, por ocasião dos períodos glaciais quaternários. Paleoclimas 3:1-19.

Abellán, P., Gómez-Zurita, J., Millán, A., Sánchez-Fernández, D., Velasco, J., Galián, J., e Ribera, I. 2007. Conservation genetics in hypersaline inland waters: mitochondrial diversity and phylogeography of an endangered Iberian beetle (Coleoptera: Hydraenidae). Conservation Genetics 8 (1):79-88.

Alexandrino, J., Arntzen, J., e Ferrand, N. 2002. Nested clade analysis and the genetic evidence for population expansion in the phylogeography of the golden-striped salamander, Chioglossa lusitanica (Amphibia: Urodela). Heredity 88 (1):66-74.

Altshul, S., Madden, T., Schaffer, A., Zhang, J., Zhang, Z., Miller, W., e Lipman, D. 1997. Gapped BLAST and PSI-BLAST: a new generation of protein database programs. Nucleic Acids Res 25:3389-3402.

Alves, R., Cardin, L., e Kropf, M. 2007. Angiosperm disjunction" Campos rupestresrestingas": a re-evaluation. Acta Botanica Brasilica 21:675-685.

Amorim, D. e Pires, M. 1996. Neotropical biogeography and a method for maximum biodiversity estimation. Biodiversity in Brazil, a first approach. São Paulo, CNPq 326:183-219.

Andrade-Lima, D. 1982. Present-day forest refuges in northeastern Brazil. Biological diversification in the tropics:245-251.

Auler, A. e Smart, P. 2001. Late quaternary paleoclimate in semiarid northeastern Brazil from U-series dating of travertine and water-table speleothems. Quaternary Research 55 (2):159-167.

Auler, A., Wang, X., Edwards, R., Cheng, H., Cristalli, P., Smart, P., e Richards, D. 2004. Quaternary ecological and geomorphic changes associated with rainfall events in presently semi arid northeastern Brazil. Journal of Quaternary Science 19 (7):693-701.

Avise, J. 2000. Phylogeography: Harvard University Press Cambridge, MA:.

Avise, J. 2009. Phylogeography: retrospect and prospect. Journal of Biogeography 36 (1):3-15.

Baimai, V., Sene, F. M., e Pereira, M. 1983. Heterochromatin and karyotypic differentiation of some neotropical cactus-breeding species of the Drosophila repleta species group. Genetica 60 (2):81-92.

Barker, J., de M. Sene, F., East, P., e Pereira, M. 1985. Allozyme and chromosomal polymorphism ofDrosophila buzzatii in Brazil and Argentina. Genetica 67 (3):161-170.

Beerli, P. 2006. Comparison of Bayesian and maximum-likelihood inference of population genetic parameters. Bioinformatics 22 (3):341.

Beerli, P. e Felsenstein, J. 1999. Maximum-likelihood estimation of migration rates and effective population numbers in two populations using a coalescent approach. Genetics 152 (2):763.

Beerli, P. e Felsenstein, J. 2001. Maximum likelihood estimation of a migration matrix and effective population sizes in $\mathrm{n}$ subpopulations by using a coalescent approach. Proceedings of the National Academy of Sciences of the United States of America 98 (8):4563. 
Behling, H. 1998. Late Quaternary vegetational and climatic changes in Brazil. Review of Palaeobotany and Palynology 99 (2):143-156.

Behling, H. 2002. Late Quaternary vegetation and climate dynamics in southeastern Amazonia inferred from Lagoa da Confusao in Tocantins State, northern Brazil. Amazoniana 17 (1):27-39.

Behling, H. e Lichte, M. 1997. Evidence of Dry and Cold Climatic Conditions at Glacial Times in Tropical Southeastern Brazil* 1. Quaternary Research 48 (3):348-358.

Behling, H., Pillar, V., Orlóci, L., e Bauermann, S. 2004. Late Quaternary Araucaria forest, grassland (Campos), fire and climate dynamics, studied by highresolution pollen, charcoal and multivariate analysis of the Cambará do Sul core in southern Brazil. Palaeogeography, Palaeoclimatology, Palaeoecology 203 (3-4):277-297.

Bermingham, E. e Moritz, C. 1998. Comparative phylogeography: concepts and applications. Molecular Ecology 7 (4):367-369.

Berry, P., Hahn, W., Sytsma, K., Hall, J., e Mast, A. 2004. Phylogenetic relationships and biogeography of Fuchsia (Onagraceae) based on noncoding nuclear and chloroplast DNA data. American Journal of Botany 91 (4):601.

Boechat, S. e Longhi-Wagner, H. 2000. Padrões de distribuição geográfica dos táxons brasileiros de Eragrostis (Poaceae, Chloridoideae). Rev. bras. Bot.[online 23 (2):177-194.

Brncic, D. 1989. Long-term changes in the population ecology of Drosophila pavani not followed by changes in the chromosomal polymorphism. Rev. bras. genét 12 (3):525.

Burkart, A. 1975. Evolution of grasses and grasslands in South America. Taxon 24 (1):53-66.

Cabrera, A. e Willink, A. 1973. Biogeografía de América Latina. Programa Regional de Desarrollo Científico y Tecnológico. Washington, DC 120.

Caetano, S., Prado, D., Pennington, R., Beck, S., Oliveira-Filho, A., Spichiger, R., e Naciri, Y. 2008. The history of seasonally dry tropical forests in eastern South America: inferences from the genetic structure of the tree Astronium urundeuva (Anacardiaceae). Molecular Ecology 17 (13):3147-3159.

Calió, M., Pirani, J., e Struwe, L. 2008. Morphology-based phylogeny and revision of Prepusa and Senaea (Gentianaceae: Helieae)—rare endemics from eastern Brazil. Kew Bulletin 63 (2):169-191.

Carnaval, A. e Bates, J. 2007. Amphibian DNA shows marked genetic structure and tracks Pleistocene climate change in northeastern Brazil. Evolution 61 (12):2942-2957.

Carnaval, A., Hickerson, M., Haddad, C., Rodrigues, M., e Moritz, C. 2009. Stability predicts genetic diversity in the Brazilian Atlantic forest hotspot. Science 323 (5915):785.

Carnaval, A. e Moritz, C. 2008. Historical climate modelling predicts patterns of current biodiversity in the Brazilian Atlantic forest. Journal of Biogeography 35 (7):1187-1201.

Carreira, V., Soto, I., Hasson, E., e Fanara, J. 2006. Patterns of variation in wing morphology in the cactophilic Drosophila buzzatii and its sibling D. koepferae. Journal of Evolutionary Biology 19 (4):1275-1282.

Carson, H. L. e Wasserman, M. 1965. A widespread chromosomal polymorphism in a widespread species, Drosophila buzzatii. The American Naturalist 99:111-115. 
Castro, A., Martins, F., Tamashiro, J., e Shepherd, G. 1999. How rich is the flora of Brazilian cerrados? Annals of the Missouri Botanical Garden 86 (1):192-224.

Clapperton, C. 1993. Quaternary geology and geomorphology of South America. Vol. 779: Amsterdam Elsevier.

Clement, M., Posada, D., e Crandall, K. 2000. TCS: a computer program to estimate gene genealogies. Molecular Ecology 9 (10):1657-1659.

Costa, L. 2003. The historical bridge between the Amazon and the Atlantic Forest of Brazil: a study of molecular phylogeography with small mammals. Journal of Biogeography 30 (1):71-86.

Costa, L., Leite, Y., Fonseca, G., e Fonseca, M. 2000. Biogeography of South American Forest Mammals: Endemism and Diversity in the Atlantic Forest1. Biotropica 32 (4b):872-881.

Coutinho, L. 2006. O conceito de bioma. Acta bot. bras 20 (1):1-11.

Cracraft, J. 1985. Historical biogeography and patterns of differentiation within the South American avifauna: areas of endemism. Ornithological Monographs:4984.

Cracraft, J. e Prum, R. 1988. Patterns and processes of diversification: speciation and historical congruence in some Neotropical birds. Evolution 42 (3):603-620.

Crandall, K. e Templeton, A. 1993. Empirical tests of some predictions from coalescent theory with applications to intraspecific phylogeny reconstruction. Genetics 134 (3):959.

da Silva, J., de Sousa, M., e Castelletti, C. 2004. Areas of endemism for passerine birds in the Atlantic forest, South America. Global Ecology and Biogeography 13 (1):85-92.

Daly, D. e Mitchell, J. 2000. Lowland vegetation of tropical South America. Imperfect balance, landscapes transformation in Precolumbian Americas (D. Lentz, org.). Columbia University Press, New York:391-453.

Darwin, C. 1859. On the origin of species by means of natural selection, or the preservation of favoured races in the struggle for life. New York: D. Appleton.

De Brito, R. A., Manfrin, M. H., e Sene, F. M. 2002a. Nested cladistic analysis of Brazilian populations of Drosophila serido. Molecular Phylogenetics and Evolution 22 (1):131-143.

De Brito, R. A., Manfrin, M. H., e Sene, F. M. 2002b. Mitochondrial DNA phylogeography of Brazilian populations of Drosophila buzzatii. Genetics and Molecular Biology 25 (2):161-171.

De Oliveira, P., Barreto, A., e Suguio, K. 1999. Late Pleistocene/Holocene climatic and vegetational history of the Brazilian caatinga: the fossil dunes of the middle Sao Francisco River. Palaeogeography, Palaeoclimatology, Palaeoecology 152 (34):319-337.

De Queiroz, L. 2006. The Brazilian Caatinga: phytogeographical patterns inferred from distribution data of the Leguminosae. Neotropical savannas and dry forests: diversity, biogeography, and conservation:121.

Di Maio, F. 1996. Revisão taxonômica do gênero Hindsia Benth.(Rubiaceae Hedyotideae). . Arquivos do Jardim Botânico do Rio de Janeiro 34:51-92.

Drummond, A. e Rambaut, A. 2007. BEAST: Bayesian evolutionary analysis by sampling trees. BMC evolutionary biology 7 (1):214.

Drummond, A., Rambaut, A., Shapiro, B., e Pybus, O. 2005. Bayesian coalescent inference of past population dynamics from molecular sequences. Molecular Biology and Evolution 22 (5):1185.

Eiten, G. 1972. The cerrado vegetation of Brazil. The Botanical Review:201-341. 
Excoffier, L. 2004. Patterns of DNA sequence diversity and genetic structure after a range expansion: lessons from the infinite island model. Molecular Ecology 13 (4):853-864.

Excoffier, L., Laval, G., e Schneider, S. 2005. Arlequin version 3.0: an integrated software package for population genetics data analysis. Evolutionary Bioinformatics Online 1:47-50.

Excoffier, L., Smouse, P. E., e Quattro, J. M. 1992. Analysis of molecular variance inferred from metric distances among DNA haplotypes: application to human mitochondrial DNA restriction data. Genetics 131:479-491.

Fanara, J. J. e Hasson, E. 2001. Oviposition acceptance and fecundity schedule in the cactophilic sibling species Drosophila buzzatii and D. koepferae on their natural hosts. Evolution 55:2615-2619.

Fiaschi, P. e Pirani, J. R. 2009. Review of plant biogeographic studies in Brazil. Journal of Systematics and Evolution 47 (5):477-496.

Fielding, A. e Bell, J. 1997. A review of methods for the assessment of prediction errors in conservation presence/absence models. Environmental conservation 24 (01):38-49.

Figueiredo, V. e Sene, F. 1992. Chromosome variability in Brazilian populations of Drosophila buzzatii (Diptera, Drosophilidae). Rev. bras. biol 52 (4):555.

Fontdevila, A. 1989. Founder effects in colonizing populations. The case of Drosophila buzzatii. Evolutionary biology of transient unstable populations:74-95.

Franco, F., Silva-Bernardi, E., Sene, F., Hasson, E., e Manfrin, M. 2010. Intra- and interspecific divergence in the nuclear sequences of the clock gene period in species of the Drosophila buzzatii cluster. Journal of Zoological Systematics and Evolutionary Research 48 (4):322-331.

Franco, F. F. 2009. História evolutiva do "cluster" Drosophila buzzatii (grupo D. repleta): eventos históricos e diversificação de espécies no Brasil. Ribeirão Preto: Universidade de São Paulo Faculdade de Medicina de Ribeirão Preto.

Franco, F. F., Kuhn, G. C., Sene, F. M., e Manfrin, M. H. 2006. Conservation of pBuM2 satellite DNA sequences among geographically isolated Drosophila gouveai populations from Brazil. Genetica 128 (1-3):287-295.

Fritsch, P., Almeda, F., Renner, S., Martins, A., e Cruz, B. 2004. Phylogeny and circumscription of the near-endemic Brazilian tribe Microlicieae (Melastomataceae). American Journal of Botany 91 (7):1105.

Fu, Y., Charlesworth, D., e Namkoong, G. 1997. Point estimation and graphical inference of marginal dominance for two. Genetical Research 70 (2):143.

Fu, Y. e Li, W. 1993. Statistical tests of neutrality of mutations. Genetics 133 (3):693.

Fu, Y. e Li, W. 1999. Coalescencing into the 21st Century: An Overview and Prospects of Coalescent Theory. Theory in Population Biology 56:1-10.

Funch, L., Rodal, M., e Funch, R. 2008. Floristic aspects of the Chapada Diamantina, Bahia, Brazil. The Atlantic coastal forests of northeastern Brazil. Memoirs of the New York Botanical Garden 100:193-220.

Galindo-Leal, C. e Câmara, I. 2003. Atlantic forest hotspots status: an overview. The Atlantic Forest of South America: biodiversity status, threats, and outlook:3-11.

Gibbard, P. e Cohen, K. M. 2008. Global chronostratigraphical correlation table for the last 2.7 million years. Episodes 31 (2):4.

Giovanelli, J., Haddad, C., e Alexandrino, J. 2008. Predicting the potential distribution of the alien invasive American bullfrog (Lithobates catesbeianus) in Brazil. Biological Invasions 10 (5):585-590. 
Giulietti, A. e Pirani, J. 1988. Patterns of geographic distribution of some plant species from the Espinhaço Range, Minas Gerais and Bahia, Brazil.

Givnish, T. e Sytsma, K. 2000. Molecular evolution and adaptive radiation: Cambridge Univ Pr.

González-Ittig, R., Patton, J., e Gardenal, C. 2007. Analysis of cytochrome-b nucleotide diversity confirms a recent range expansion in Calomys musculinus (Rodentia, Muridae). Journal of Mammalogy 88 (3):777-783.

González, J., Nefedov, M., Bosdet, I., Casals, F., Calvete, O., Delprat, A., Shin, H., Chiu, R., Mathewson, C., e Wye, N. 2005. A BAC-based physical map of the Drosophila buzzatii genome. Genome research 15 (6):885.

Gottsberger, G. e Silberbauer-Gottsberger, I. 2006. Life in the cerrado: A South American tropical seasonal ecosystem: Abteilung Systematische Botanik und Ökologie und Botanischer Garte, Universität Ulm.

Granville, J. 1992. Un cas de distribution particulier: les espèces forestières periamazoniennes. Compte-Rendu des Séances de la Societé de Biogéographie 68:133.

Gray, D., Huang, H., e Knowles, L. 2008. Molecular evidence of a peripatric origin for two sympatric species of field crickets (Gryllus rubens and G. texensis) revealed from coalescent simulations and population genetic tests. Molecular Ecology 17 (17):3836-3855.

Haffer, J. 1969. Speciation in Amazonian forest birds. Science 165 (3889):131-137.

Hall, T. 1999. BioEdit: a user-friendly biological sequence alignment editor and analysis program for Windows 95/98/NT.

Harley, R. e Stannard, B. 1995. Flora of the Pico das Almas, Chapada DiamantinaBahia, Brazil. Royal Botanic Gardens.[Links].

Hasegawa, M., Kishino, H., e Yano, T. 1985. Dating of the human-ape splitting by a molecular clock of mitochondrial DNA. Journal of molecular evolution 22 (2):160-174.

Heads, M. 2009. Darwin's changing views on evolution: from centres of origin and teleology to vicariance and incomplete lineage sorting. Journal of Biogeography 36 (6):1018-1026.

Hewitt, G. 2000. The genetic legacy of the Quarternary ice ages. Nature 405:907-913.

Hijmans, R., Cameron, S., Parra, J., Jones, P., e Jarvis, A. 2005. Very high resolution interpolated climate surfaces for global land areas. International Journal of Climatology 25 (15):1965-1978.

Hurtado, L., Erez, T., Castrezana, S., e Markow, T. 2004. Contrasting population genetic patterns and evolutionary histories among sympatric Sonoran Desert cactophilic Drosophila. Molecular Ecology 13 (6):1365-1375.

Iriarte, P. F. e Hasson, E. 2000. The role of the use of different host plants in the maintenance of the inversion polymorphism in the cactophilic Drosophila buzzatii. Evolution 54:1295-1302.

Joseph, L., Wilke, T., e Alpers, D. 2002. Reconciling genetic expectations from host specificity with historical population dynamics in an avian brood parasite, Horsfield's Bronze Cuckoo Chalcites basalis of Australia. Molecular Ecology 11 (4):829-837.

Katinas, L. e Crisci, J. 2008. Reconstructing the biogeographical history of two plant genera with different dispersion capabilities. Journal of Biogeography 35 (8):1374-1384.

Kingman, J. 1982. The coalescent. Stochastic processes and their applications 13 (3):235-248. 
Klein, R. 1960. O aspecto dinâmico do pinheiro brasileiro. Sellowia 12 (12):17-48.

Knowles, L. 2008. Why does a method that fails continue to be used? Evolution 62 (11):2713-2717.

Knowles, L. e Maddison, W. P. 2002. Statistical phylogeography. Mol Ecol 11 (12):2623-2635.

Kotlik, P., Bogutskaya, N., e Ekmekci, F. 2004. Circum Black Sea phylogeography of Barbus freshwater fishes: divergence in the Pontic glacial refugium. Molecular Ecology 13 (1):87-95.

Kuhn, G.C.S., Franco, F.F., Silva Jr., W.A., Martinez-Rossi, N.M. e Sene, F.M. 2003. On the pBuM189 satellite DNA variability among South American populations of Drosophila buzzatii. Hereditas (139): 161-166.

Kuhn, G., Franco, F., Manfrin, M., Moreira-Filho, O., e Sene, F. 2007. Low rates of homogenization of the DBC-150 satellite DNA family restricted to a single pair of microchromosomes in species from the Drosophila buzzatii cluster. Chromosome Research 15 (4):457-470.

Lavin, M. 2006. Floristic and geographical stability of discontinuous seasonally dry tropical forests explains patterns of plant phylogeny and endemism. SYSTEMATICS ASSOCIATION SPECIAL VOLUME 69:433.

Lavin, M., Thulin, M., Labat, J., e Pennington, R. 2000. Africa, the odd man out: molecular biogeography of dalbergioid legumes (Fabaceae) suggests otherwise. Systematic Botany 25 (3):449-467.

Ledru, M. 1991. Late Quaternary environment and climatic changes in central Brazil. . Quaternary Research 39:90-98.

Ledru, M., Ceccantini, G., Gouveia, S., López-Sáez, J., Pessenda, L., e Ribeiro, A. 2006. Millenial-scale climatic and vegetation changes in a northern Cerrado (Northeast, Brazil) since the Last Glacial Maximum. Quaternary Science Reviews 25 (9-10):1110-1126.

Ledru, M., Rousseau, D., e Cruz, F. 2005. Paleoclimate changes during the last 100,000 yr from a record in the Brazilian Atlantic rainforest region and interhemispheric comparison. Quaternary Research 64 (3):444-450.

Leite, P. 2002. Contribuição ao conhecimento fitoecológico do sul do Brasil. Ciência e Ambiente 24:51-73.

Manel, S., Williams, H., e Ormerod, S. 2001. Evaluating presence-absence models in ecology: the need to account for prevalence. Journal of Applied Ecology 38 (5):921-931.

Manfrin, M. H., De Brito, R. A., e Sene, F. M. 2001. Systematics and evolution of the Drosophila buzzatii (Diptera: Drosophilidae) cluster using mtDNA. Annals of the Entomological Society of America 94 (3):333-346.

Manfrin, M. H. e Sene, F. M. 2006. Cactophilic Drosophila in South America: A model for evolutionary studies. Genetica 126 (1-2):57-75.

Mantel, N. 1967. The detection of disease clustering and a generalized regression approach. Cancer research 27 (2 Part 1):209.

Marín, J., Spotorno, A., González, B., Bonacic, C., Wheeler, J., Casey, C., Bruford, M., Palma, R., e Poulin, E. 2008. Mitochondrial DNA variation and systematics of the guanaco (Lama guanicoe, Artiodactyla: Camelidae). Journal of Mammalogy 89 (2):269-281.

Mateus, R. P. e Sene, F. M. 2007. Population genetic study of allozyme variation in natural populations of Drosophila antonietae (Insecta, Diptera). Journal of Zoological Systematics and Evolutionary Research 45 (2):136-143. 
Mayle, F., Beerling, D., Gosling, W., e Bush, M. 2004. Responses of Amazonian ecosystems to climatic and atmospheric carbon dioxide changes since the last glacial maximum. Philosophical Transactions of the Royal Society of London. Series B: Biological Sciences 359 (1443):499.

Mayr, E. 1977. Populações, espécies e evolução, Companhia Editora Nacional. São Paulo: Editora da Universidade de São Paulo.

Méio, B., Freitas, C., Jatobá, L., Silva, M., Ribeiro, J., e Henriques, R. 2003. Influência da flora das florestas Amazônica e Atlântica na vegetação do cerrado sensu stricto. Revista Brasileira de Botânica 26 (4):437-444.

Melo Santos, A., Cavalcanti, D., Silva, J., e Tabarelli, M. 2007. Biogeographical relationships among tropical forests in north eastern Brazil. Journal of Biogeography 34 (3):437-446.

Mendonça, R., Felfili, J., Water, B., Silva Junior, M., Rezende, A., Filgueiras, T., e Nogueira, P. 1998. Flora vascular do cerrado. In Cerrado: Ambiente e flora, edited by S. Sano and S. Almeida: Planaltina: Embrapa.

Mora, M., Lessa, E., Kittlein, M., e Vassallo, A. 2006. Phylogeography of the subterranean rodent Ctenomys australis in sand-dune habitats: evidence of population expansion. Journal of Mammalogy 87 (6):1192-1203.

Moraes, E.M., Spressola, V.L., Prado, P.R.R., Costa, L.F. e Sene, F.M. 2004. Divergence in wing morphology among sibling species of the Drosophila buzzatii cluster. J. Zool. Syst. Evol. Res. (42): 154-158.

Moraes, E., Yotoko, K., Manfrin, M., Solferini, V., e Sene, F. 2009. Phylogeography of the cactophilic species Drosophila gouveai: demographic events and divergence timing in dry vegetation enclaves in eastern Brazil. Journal of Biogeography 36 (11):2136-2147.

Morales, A. C. 2005. Análise histórico-evolutiva de populações das espécies cactofílicas Drosophila serido e Drosophila antonietae (Diptera: Drosophilidae), Faculdade de Filosofia, Ciências e Letras de Ribeirão Preto, Universidade de São Paulo, Ribeirão Preto.

Morello, J. e Adámoli, J. 1967. Vegetación y ambiente del nordeste del Chaco argentino. Guía de viaje, tramo Resistencia-Puerto Pilcomayo. IX Jorn. Arg. Bot. INTA, Centro Regional Chaqueño, EEA, Cnia. Benitez, mimeog 75.

Mori, S., Boom, B., e Prance, G. 1981. Distribution patterns and conservation of eastern Brazilian coastal forest tree species. Brittonia 33 (2):233-245.

Morrone, J. 2006. Biogeographic areas and transition zones of Latin America and the Caribbean Islands based on analyses of the entomofauna. Annual Review of Entomology 51:467-94.

Myers, N., Mittermeier, R., Mittermeier, C., da Fonseca, G., e Kent, J. 2000. Biodiversity hotspots for conservation priorities. Nature 403 (6772):853-858.

Nagaraju, J. e Ranganath, H. 2004. Molecular phylogeny of the nasuta subgroup of Drosophila based on 12S rRNA, 16S rRNA and CoI mitochondrial genes, RAPD and ISSR polymorphisms. Genes \& Genetic Systems 79 (5):293-299.

Negre, B., Casillas, S., Suzanne, M., Sánchez-Herrero, E., Akam, M., Nefedov, M., Barbadilla, A., De Jong, P., e Ruiz, A. 2005. Conservation of regulatory sequences and gene expression patterns in the disintegrating Drosophila Hox gene complex. Genome research 15 (5):692.

Nielsen, R. e Beaumont, M. 2009. Statistical inferences in phylogeography. Molecular Ecology 18 (6):1034-1047. 
Oliveira-Filho, A. e Fontes, M. 2000. Patterns of Floristic Differentiation among Atlantic Forests in Southeastern Brazil and the Influence of Climate1. Biotropica 32 (4b):793-810.

Oliveira-Filho, A., Jarenkow, J., Jesus, M., e Rodal, N. 2006. T Floristic Relationships of Seasonally Dry Forests of Eastern South America Based on Tree Species Distribution Patterns. Neotropical savannas and dry forests: diversity, biogeography, and conservation:159.

Oliveira-Filho, A. e Ratter, J. 1995. A study of the origin of central Brazilian forests by the analysis of plant species distribution patterns. Edinb. J. Bot 52 (2):141-194.

Ortiz-Jaureguizar, E. e Cladera, G. 2006. Paleoenvironmental evolution of southern South America during the Cenozoic. Journal of Arid Environments 66 (3):498532.

Overbeck, G., Müller, S., Fidelis, A., Pfadenhauer, J., Pillar, V., Blanco, C., Boldrini, I., Both, R., e Forneck, E. 2007. Brazil's neglected biome: the South Brazilian Campos. Perspectives in Plant Ecology, Evolution and Systematics 9 (2):101116.

Overbeck, G., Müller, S., Pillar, V., e Pfadenhauer, J. 2006. Floristic composition, environmental variation and species distribution patterns in burned grassland in southern Brazil. Brazilian Journal of Biology 66:1073-1090.

Panchal, M. e Beaumont, M. 2007. The automation and evaluation of nested clade phylogeographic analysis. Evolution 61 (6):1466-1480.

Peck, D. e Congdon, B. 2004. Reconciling historical processes and population structure in the sooty tern Sterna fuscata. Journal of Avian Biology 35 (4):327-335.

Pennington, R. e Dick, C. 2004. The role of immigrants in the assembly of the South American rainforest tree flora. Philosophical Transactions of the Royal Society of London. Series B: Biological Sciences 359 (1450):1611.

Pennington, R., Lewis, C., e Ratter, J. 2006. An overview of the plant diversity, biogeography and conservation of neotropical savannas and seasonally dry forests. Neotropical savannas and dry forests: diversity, biogeography, and conservation:1.

Pennington, R., Prado, D., e Pendry, C. 2000. Neotropical seasonally dry forests and Quaternary vegetation changes. Journal of Biogeography 27 (2):261-273.

Pereira, M. A. Q. R., Vilela, C. R., e Sene, F. M. 1983. Notes on breeding and feeding sites of some species of the repleta group of the genus Drosophila (Diptera, Drosophilidae). Ciência e Cultura 35:1313-1319.

Perret, M., Chautems, A., e Spichiger, R. 2006. Dispersal-vicariance analyses in the tribe Sinningieae (Gesneriaceae): a clue to understanding biogeographical history of the Brazilian Atlantic forest. Annals of the Missouri Botanical Garden 93 (2):340-358.

Petit, R. 2008. The coup de grâce for the nested clade phylogeographic analysis? Molecular Ecology 17 (2):516-518.

Phillips, S., Anderson, R., e Schapire, R. 2006. Maximum entropy modeling of species geographic distributions. Ecological modelling 190 (3-4):231-259.

Piccinali, R. V., Mascord, L. J., Barker, J. S. F., Oakeshott, J. G., e Hasson, E. 2007. Molecular population genetics of the alpha-esterase 5 gene locus in original and colonized populations of Drosophila buzzatii and its sibling Drosophila koepferae. Journal of molecular evolution 64 (2):158-170.

Pinto-da-Rocha, R., da Silva, M., e Bragagnolo, C. 2005. Faunistic similarity and historic biogeography of the harvestmen of southern and southeastern Atlantic Rain Forest of Brazil. Journal of Arachnology 33 (2):290-299. 
Pirani, J. 1990. Diversidade taxonomica e padroes de distribuicao geografica em Picramnia (Simaroubaceae) no Brasil.(Taxonomic diversity and geographic distribution patterns of Picramnia (Simaroubaceae) in Brazil.). Acta Bot. Brasil 4 (1):19-44.

Poljak, S., Confalonieri, V., Fasanella, M., Gabrielli, M., e Lizarralde, M. Phylogeography of the armadillo Chaetophractus villosus (Dasypodidae Xenarthra): Post-glacial range expansion from Pampas to Patagonia (Argentina). Molecular Phylogenetics and Evolution 55 (1):38-46.

Posada, D. e Crandall, K. 2001. Intraspecific gene genealogies: trees grafting into networks. Trends in Ecology \& Evolution 16 (1):37-45.

Posada, D., Crandall, K., e Templeton, A. 2000. GeoDis: a program for the cladistic nested analysis of the geographical distribution of genetic haplotypes. Molecular Ecology 9 (4):487-488.

Powell, J. 1997. Progress and prospects in evolutionary biology: the Drosophila model: Oxford University Press, USA.

Prado, D. 2000. Seasonally dry forests of tropical South America: from forgotten ecosystems to a new phytogeographic unit. Edinburgh Journal of Botany 57 (03):437-461.

Prado, D. e Gibbs, P. 1993. Patterns of species distributions in the dry seasonal forests of South America. Annals of the Missouri Botanical Garden 80 (4):902-927.

Prance, G. 1979. The taxonomy and phytogeography of the Chrysobalanaceae of the Atlantic coastal forests of Brazil. Rev. Brasil. Bot 2 (1):19-39.

Prance, G. 1982. A review of the phytogeographic evidences for Pleistocene climate changes in the Neotropics. Annals of the Missouri Botanical Garden 69: 594624.

Prance, G. 1988. Padrões de distribuição e especiação em Chrysobalanaceae e outras famílias de plantas amazônicas. Acta Bot. Brasil 1 (2):1-25.

Prance, G. 1996. Islands in Amazonia. Philosophical Transactions: Biological Sciences 351 (1341):823-833.

Quijada-Mascareñas, J., Ferguson, J., Pook, C., Salomão, M., Thorpe, R., e Wüster, W. 2007. Phylogeographic patterns of trans-Amazonian vicariants and Amazonian biogeography: the Neotropical rattlesnake (Crotalus durissus complex) as an example. Journal of Biogeography 34 (8):1296-1312.

Rambo, B. 1956. A flora fanerogâmica dos Aparados riograndenses. Sellowia 7:235298.

Rapini, A., Van Den Berg, C., e Liede-Schumann, S. 2007. Diversification of Asclepiadoideae (Apocynaceae) in the New World1. Annals of the Missouri Botanical Garden 94 (2):407-422.

Ratter, J., Bridgewater, S., e Ribeiro, J. 2006. Biodiversity patterns of the woody vegetation of the Brazilian Cerrado. Neotropical savannas and seasonlly dry forests: plant diversity, biogeography, and conservation:31.

Ratter, J., Ribeiro, J., e Bridgewater, S. 1997. The Brazilian cerrado vegetation and threats to its biodiversity. Annals of Botany 80 (3):223.

Ray, N., Currat, M., e Excoffier, L. 2003. Intra-deme molecular diversity in spatially expanding populations. Molecular Biology and Evolution 20 (1):76.

Ritter, M. e Waechter, J. 2004. Biogeografia do genero Mikania Willd.(Asteraceae) no Rio Grande do Sul, Brasil.(Biogeography of the genus Mikania Willd.(Asteraceae) in Rio Grande do Sul, Brazil.). Acta Bot. Brasil 18:643-652.

Ritz, C., Martins, L., Mecklenburg, R., Goremykin, V., e Hellwig, F. 2007. The molecular phylogeny of Rebutia (Cactaceae) and its allies demonstrates the 
influence of paleogeography on the evolution of South American mountain cacti. American Journal of Botany 94 (8):1321.

Rodal, M. e Sales, M. 2008. Panorama of the montane forests of Pernambuco, Brazil. The Atlantic coastal forests of northeastern Brazil. Memoirs of the New York Botanical Garden 100:541-559.

Rodriguez-Trelles, F., Alarcón, L. e Fontdevila, A. 2000. Molecular Evolution and phylogeny of the buzzatii complex (Drosophila repleta group): a maximumlikelihood approach. Mol. Biol. Evol. (17): 1112-1122.

Rogers, A. e Harpending, H. 1992. Population growth makes waves in the distribution of pairwise genetic differences. Molecular Biology and Evolution 9 (3):552.

Rossi, M. S., Barrio, E., Latorre, A., QuezadaDiaz, J. E., Hasson, E., Moya, A., e Fontdevila, A. 1996. The evolutionary history of Drosophila buzzatii .30. Mitochondrial DNA polymorphism in original and colonizing populations. Molecular Biology and Evolution 13 (2):314-323.

Rozas, J., Sánchez-DelBarrio, J., Messeguer, X., e Rozas, R. 2003. DnaSP, DNA polymorphism analyses by the coalescent and other methods. Bioinformatics 19 (18):2496.

Ruiz, A., Cansian, A. M., Kuhn, G. C. S., Alves, M. A. R., e Sene, F. M. 2000. The Drosophila serido speciation puzzle: putting new pieces together. Genetica 108:217-227.

Ruiz, A., Naveira, H., e Fontdevila, A. 1984. La historia evolutiva de Drosophila buzzatii. IV. Aspectos citogenéticos de su polimorfismo cromosómico. Genética Ibérica 36:13-35.

Ruiz, A. e Wasserman, M. 1993. Evolutionary cytogenetics of the Drosophila buzzatii species complex. Heredity 70:582-596.

Russo, C., Takezaki, N., e Nei, M. 1995. Molecular phylogeny and divergence times of drosophilid species. Molecular Biology and Evolution 12 (3):391.

Safford, D. 1999. Brazilian Páramos I. An introduction to the physical environment and vegetation of the campos de altitude. Journal of Biogeography 26 (4):693-712.

Safford, D. 2007. Brazilian Páramos IV. Phytogeography of the campos de altitude. Journal of Biogeography 34 (10):1701-1722.

Salgado-Labouriau, M. 1994. História ecológica da Terra. Edgard Blücher.

Sampaio, E. 1995. Overview of the Brazilian Caatinga. In.: Bullock, SH Mooney; Medina, E. Seasonally dry tropical forests: Cambrige University Press.

Santana-Neto, J., Nery, J., Souza, C., Suguio, K., Oliveira, A., e Oliveira, P. 2005. Variabilidade e mudanças climáticas no Brasil e seus impactos regionais. Quaternário do Brasil (CRG Souza, K. Suguio, AMSP Oliveira \& PE Oliveira, eds.). Holos Editora, Ribeirão Preto:28-51.

Santos, C. 2009. Estrutura populacional da espécie Drosophila buzzatii (Diptera, Drosophilidae) determinada através de morfometria da asa, Faculdade de Ciências Agrárias e Veterinárias - UNESP, Campus Jaboticabal, Univeridade Estadual Paulista, Jaboticabal.

Santos, C. e Manfrin, M. 2010. Morphological variation of the aedagus in Drosophila buzzatii (Diptera, Drosophilidae). Drosophila Information Service 93:no prelo.

Santos, M., Lopes, I., e Del Lama, S. 2008. Population Genetic Study of Mitochondrial DNA in Roseate Spoonbill (Aves; Platalea ajaja) Breeding Colonies from the Pantanal Wetlands, Brazil. Biochemical Genetics 46 (7):492-505.

Saslis-Lagoudakis, C., Chase, M., Robinson, D., Russell, S., e Klitgaard, B. 2008. Phylogenetics of neotropical Platymiscium (Leguminosae: Dalbergieae): systematics, divergence times, and biogeography inferred from nuclear 
ribosomal and plastid DNA sequence data. American Journal of Botany 95 (10):1270.

Scarano, F. 2002. Structure, function and floristic relationships of plant communities in stressful habitats marginal to the Brazilian Atlantic Rainforest. Annals of Botany 90 (4):517.

Schilling, E., Da Costa, F., Lopes, N., e Heise, P. 2000. Brazilian species of Viguiera (Asteraceae) exhibit low levels of ITS sequence variation. Edinburgh Journal of Botany 57 (03):323-332.

Sene, F. M., Pereira, M. A. Q. R., e Vilela, C. R. 1982. Evolutionary aspects of cactus breeding Drosophila in South America. In Ecological Genetics and Evolution. The Cactus-Yeast-Drosophila Model System, edited by J. S. F. B. a. W. T. Starmer. Sydney: Academic Press.

Sene, F. M., Pereira, M. A. Q. R., e Vilela, C. R. 1988. Contrasting patterns of differentiation inferred from traditional genetic markers in the process of speciation. Pacific Science 42 (1-2):81-88.

Silva, A. F. G. e Sene, F. M. 1991. Morphological geographic variability in Drosophila serido (Diptera, Drosophilidae). Revista Brasileira de Entomologia 35:455-468.

Simon, C., Frati, F., Beckenbach, A., Crespi, B., Liu, H., e Flook, P. 1994. Evolution, Weighting, and Phylogenetic Utility of Mitochondrial Gene-Sequences and a Compilation of Conserved Polymerase Chain-Reaction Primers. Annals of the Entomological Society of America 87 (6):651-701.

Slatkin, M. e Hudson, R. 1991. Pairwise comparisons of mitochondrial DNA sequences in stable and exponentially growing populations. Genetics 129 (2):555.

Smith, L. 1962. Origins of the Flora of Southern Brazil: A Synopsis of the American Velloziaceae: Smithsonian Institution.

Smouse, P., Long, J., e Sokal, R. 1986. Multiple regression and correlation extensions of the Mantel test of matrix correspondence. Systematic Biology 35 (4):627.

Soderstrom, T., Judziewicz, E., e Clark, L. 1988. Distribution patterns of Neotropical bamboos. In Proceedings of a workshop on Neotropical distribution patterns, edited by P. Vanzolini and W. Heyer. Rio de Janeiro: Academia Brasileira de Ciências.

Soriano, A. 1992. Río de la Plata grasslands. Ecosystems of the world 8:367-407.

Soto, I., Carreira, V., Fanara, J., e Hasson, E. 2007. Evolution of male genitalia: environmental and genetic factors affect genital morphology in two Drosophila sibling species and their hybrids. BMC evolutionary biology 7 (1):77.

Starmer, W.T., M. Lachance, H.J. Phaff e W.B. Heed, 1990. The biogeography of yeasts associated with decaying cactus tissue in North America the Caribbean and northern Venezuela. Evol. Biol. (24): 253-296.Suguio, K., Sallun, A., e A. Soares, E. 2005. Quaternary:“Quo Vadis”? Rev. Bras. Geociências 28 (003):197-200.

Tajima, F. 1989. Statistical method for testing the neutral mutation hypothesis by DNA polymorphism. Genetics 123 (3):585.

Tamura, K., Dudley, J., Nei, M., e Kumar, S. 2007. MEGA4: molecular evolutionary genetics analysis (MEGA) software version 4.0. Molecular Biology and Evolution 24 (8):1596.

Tamura, K. e Nei, M. 1993. Estimation of the number of nucleotide substitutions in the control region of mitochondrial DNA in humans and chimpanzees. Molecular Biology and Evolution 10 (3):512.

Taylor, N. e Zappi, D. 2004. Cacti of eastern Brazil. Kew: Royal Botanic Gardens, Kew xii, 499p.-col. illus.. ISBN 1842460560. 
Templeton, A. 2004. Statistical phylogeography: methods of evaluating and minimizing inference errors. Molecular Ecology 13 (4):789-809.

Templeton, A. 2009. Why does a method that fails continue to be used? The answer. Evolution 63 (4):807-812.

Templeton, A., Boerwinkle, E., e Sing, C. 1987. A cladistic analysis of phenotypic associations with haplotypes inferred from restriction endonuclease mapping. I. Basic theory and an analysis of alcohol dehydrogenase activity in Drosophila. Genetics 117 (2):343.

Templeton, A. R. 1998. Nested clade analyses of phylogeographic data: testing hypotheses about gene flow and population history. Molec. Ecol. 7:381-397.

Templeton, A. R., Routman, E., e Phillips, C. A. 1995. Separating population structure from population history: A cladistic analysis of the geographical distribution of mitochondrial DNA haplotypes in the tiger salamander, Ambystoma tigrinum. Genetics 140:767-782.

Thomas, R. e Barker, J. 1990. Breeding structure of natural populations of Drosophila buzzatii: effects of the distribution of larval substrates. Heredity 64:355-365.

Thomas, W. e Barbosa, M. 2008. Natural vegetation types in the Atlantic Coastal Forest of Northeastern Brazil. The Atlantic Coastal Forests of Northeastern Brazil (WW Thomas, ed.). Mem. New York Bot. Gard 100:6-20.

Thomé, M., Zamudio, K., Giovanelli, J., Haddad, C., Baldissera Jr, F., e Alexandrino, J. 2010. Phylogeography of endemic toads and post-Pliocene persistence of the Brazilian Atlantic Forest. Molecular Phylogenetics and Evolution 55 (3):10181031.

Thompson, J., Higgins, D., e Gibson, T. 1994. CLUSTAL W: improving the sensitivity of progressive multiple sequence alignment through sequence weighting, position-specific gap penalties and weight matrix choice. Nucleic Acids Research 22 (22):4673.

Tidon-Sklorz, R. e Sene, F. M. 2001. Drosophila antonietae sp. n. and Drosophila gouveai sp. n.: Two new species of the Drosophila serido superspecies taxon (Diptera, Drosophilidae). Iheringia, série Zoologia 90:141-146.

Vanzolini, P. e Williams, E. 1970. South American anoles: the geographic differentiation and evolution of the Anolis chrysolepis species group (Sauria, Iguanidae).

Vilela, C., Sene, F., e Pereira, M. 1980. On the Drosophila fauna of Chaco and east slopes of the Andes in Argentina. Rev. bras. biol 40:837-841.

Vilela, C. R. 1983. A revision of the Drosophila repleta species group (Diptera: Drosophilidae). Revista Brasileira de Entomologia 27:1-114.

Vilela, C. R., Sene, F. M., e Pereira, M. A. Q. R. 1980. On the Drosophila fauna of chaco and east slopes of the Andes in Argentina. Revista Brasileira de Biologia 40 (4):837-841.

Waechter, J. 2002. Padrões geográficos na flora atual do Rio Grande do Sul. Ciência \& Ambiente 24:93-108.

Wang, X., Auler, A., Edwards, R., Cheng, H., Cristalli, P., Smart, P., Richards, D., e Shen, C. 2004. Wet periods in northeastern Brazil over the past $210 \mathrm{kyr}$ linked to distant climate anomalies. Nature 432 (7018):740-743.

Werle, E., Schneider, C., Renner, M., Völker, M., e Fiehn, W. 1994. Convenient singlestep, one tube purification of PCR products for direct sequencing. Nucleic Acids Research 22 (20):4354.

Werneck, F., Costa, G., Colli, G., Prado, D., e Sites, J. 2010. Revisiting the historical distribution of Seasonally Dry Tropical Forests: new insights based on 
palaeodistribution modelling and palynological evidence. Global Ecology and Biogeography.

Wilson, A., Stoneking, M., e Cann, R. 1987. Mitochondrial DNA and human evolution. Nature 325:31-33.

Wirth, T. e Bernatchez, L. 2001. Genetic evidence against panmixia in the European eel. Nature 409 (6823):1037-1040.

Wright, S. 1931. Evolution in Mendelian populations. Genetics 16:97-159.

Wüster, W., Ferguson, J., Quijada-Mascareñas, J., Pook, C., Salomão, M., e Thorpe, R. 2005. Tracing an invasion: landbridges, refugia, and the phylogeography of the Neotropical rattlesnake (Serpentes: Viperidae: Crotalus durissus). Molecular Ecology 14:1095-1108.

Zanella, F. 2010. Padrões da Biota da Diagonal de Formações Abertas e Secas da América do Sul. In Biogeografia da América do Sul Padrões \& Processos, edited by C. Carvalho and E. Almeida. São Paulo: Roca Editora.

Zeisset, I. e Beebee, T. 2008. Amphibian phylogeography: a model for understanding historical aspects of species distributions. Heredity 101 (2):109-119. 
Tabela 9. Localização das amostras utilizadas para as análises de Modelagem de Nicho Ecológico de indivíduos da espécie $D$. buzzatii e suas coordenadas geográficas. Os números após as localidades indicam nova amostragem em localidades próximas.

\begin{tabular}{|c|c|c|c|}
\hline Localização & Estado/País & Longitude & Latitude \\
\hline Acosta & Argentina & -65.200000 & -25.500000 \\
\hline Agua Blanca & Argentina & -67.200000 & -29.000000 \\
\hline Aguilan & Argentina & -67.483333 & -29.200000 \\
\hline Amaicha del Valle & Argentina & -65.900000 & -26.600000 \\
\hline Bajas & Argentina & -65.600000 & -28.400000 \\
\hline Belén de Escobar 1 & Argentina & -58.800000 & -34.300000 \\
\hline Belén de Escobar 2 & Argentina & -58.800000 & -34.300000 \\
\hline Buenos Aires & Argentina & -58.700000 & -34.400000 \\
\hline Calamarca & Argentina & -66.300000 & -28.800000 \\
\hline Catamarca 2 & Argentina & -66.400000 & -28.800000 \\
\hline Catamarca 3 & Argentina & -66.300000 & -28.800000 \\
\hline Choromoro & Argentina & -65.400000 & -26.500000 \\
\hline Colonia Popular & Argentina & -59.116667 & -27.283333 \\
\hline El Alto & Argentina & -65.400000 & -28.300000 \\
\hline El Chaquito & Argentina & -62.050000 & -22.850000 \\
\hline Fontana & Argentina & -59.100000 & -27.400000 \\
\hline Formoso & Argentina & -61.850833 & -23.899444 \\
\hline Jujuy 1 & Argentina & -64.500000 & -23.600000 \\
\hline Jujuy 2 & Argentina & -64.500000 & -23.600000 \\
\hline La Calera & Argentina & -65.900000 & -27.500000 \\
\hline La Cruz & Argentina & -64.491944 & -32.307222 \\
\hline La Rioja 1 & Argentina & -66.800000 & -30.100000 \\
\hline La Rioja 2 & Argentina & -66.933333 & -30.000000 \\
\hline Lora Huasi & Argentina & -66.000000 & -26.100000 \\
\hline Los Colorados & Argentina & -67.300000 & -29.750000 \\
\hline Mar Chiquita & Argentina & -62.700000 & -30.400000 \\
\hline $\begin{array}{l}\text { Matheu/Buenos } \\
\text { Aires }\end{array}$ & Argentina & -58.800000 & -34.400000 \\
\hline Missiones & Argentina & -54.670833 & -26.561944 \\
\hline Pueblo Viejo & Argentina & -65.566667 & -27.983333 \\
\hline Salta 1 & Argentina & -65.400000 & -24.800000 \\
\hline Salta 2 & Argentina & -65.100000 & -24.700000 \\
\hline Salta 3 & Argentina & -65.200000 & -25.100000 \\
\hline $\begin{array}{l}\text { San Antonio de } \\
\text { Arredondo }\end{array}$ & Argentina & -64.400000 & -31.400000 \\
\hline San Lorenzo & Argentina & -64.500000 & -28.000000 \\
\hline San Luis 1 & Argentina & -66.349722 & -33.299722 \\
\hline San Luis 2 & Argentina & -66.200000 & -33.200000 \\
\hline San Luis 3 & Argentina & -66.500000 & -33.300000 \\
\hline San Luis 4 & Argentina & -66.600000 & -33.400000 \\
\hline Santa Fe & Argentina & -59.900000 & -29.300000 \\
\hline Tucumán 1 & Argentina & -65.900000 & -26.600000 \\
\hline Tucumán 2 & Argentina & -65.233333 & -26.650000 \\
\hline Tucumán 3 & Argentina & -65.266667 & -26.583333 \\
\hline Tucumán 4 & Argentina & -65.300000 & -26.500000 \\
\hline
\end{tabular}




\begin{tabular}{|c|c|c|c|}
\hline Tucumán 5 & Argentina & -65.900000 & -27.500000 \\
\hline Vale Fértil & Argentina & -67.474722 & -30.633056 \\
\hline Villa Dolores & Argentina & -65.200000 & -32.000000 \\
\hline Yanda & Argentina & -64.300000 & -27.900000 \\
\hline Barreiras & BA/Brasil & -45.250000 & -12.100000 \\
\hline $\begin{array}{l}\text { Estrada Morro do } \\
\text { Chapéu BA }\end{array}$ & BA/Brasil & -41.316667 & -11.483333 \\
\hline Ibotirama & BA/Brasil & -43.066667 & -12.266667 \\
\hline Irecê & BA/Brasil & -41.783333 & -11.333333 \\
\hline $\begin{array}{l}\text { Luís Eduardo } \\
\text { Magalhães }\end{array}$ & BA/Brasil & -45.716667 & -12.066667 \\
\hline Manoel Vitorino & BA/Brasil & -40.233333 & -14.133333 \\
\hline Milagres & BA/Brasil & -39.883333 & -12.850000 \\
\hline $\begin{array}{l}\text { Morro do Chapéu } \\
\text { BA }\end{array}$ & BA/Brasil & -41.168889 & -11.548889 \\
\hline Morro Torre & BA/Brasil & -40.250000 & -9.933333 \\
\hline Salvador & BA/Brasil & -38.450000 & -12.95000 \\
\hline Xique-Xique & BA/Brasil & -42.716667 & -10.866667 \\
\hline $\begin{array}{l}\text { San } \\
\text { Isidro/Cochabamba } \\
1\end{array}$ & Bolívia & -64.500000 & -18.100000 \\
\hline $\begin{array}{l}\text { San } \\
\text { Isidro/Cochabamba } \\
2\end{array}$ & Bolívia & -64.600000 & -18.100000 \\
\hline Cristalina & GO/Brasil & -47.666667 & -16.716667 \\
\hline Cardeal Mota & MG/Brasil & -43.583333 & -19.283333 \\
\hline $\begin{array}{l}\text { Conceição do Mato } \\
\text { Dentro } 1\end{array}$ & MG/Brasil & -43.433333 & -19.066667 \\
\hline $\begin{array}{l}\text { Conceição do Mato } \\
\text { Dentro } 2\end{array}$ & MG/Brasil & -43.550000 & -19.283333 \\
\hline $\begin{array}{l}\text { Conceição do Mato } \\
\text { Dentro } 3\end{array}$ & MG/Brasil & -43.666667 & -19.000000 \\
\hline Delfinópolis & MG/Brasil & -46.783333 & -20.333333 \\
\hline Estreito & MG/Brasil & -47.266667 & -20.150000 \\
\hline Furnas & MG/Brasil & -46.250000 & -20.616667 \\
\hline Grão Mogol & MG/Brasil & -42.833333 & -16.533333 \\
\hline $\begin{array}{l}\text { Morro do Chapéu } \\
\text { MG }\end{array}$ & MG/Brasil & -47.383333 & -20.050000 \\
\hline Nova Ponte & MG/Brasil & -47.683333 & -19.133333 \\
\hline Serra do Cipó & MG/Brasil & -43.633333 & -19.333333 \\
\hline Bela Vista & MS/Brasil & -56.783333 & -22.216667 \\
\hline Miranda & MS/Brasil & -56.666667 & -20.183333 \\
\hline Piraputanga & MS/Brasil & -55.516667 & -20.416667 \\
\hline Bella Vista Norte & Paraguai & -56.533333 & -22.133333 \\
\hline Junco do Seridó 1 & PB/Brasil & -36.702222 & -7.006944 \\
\hline Junco do Seridó 2 & PB/Brasil & -36.700000 & -6.983333 \\
\hline $\begin{array}{l}\text { Riachão do } \\
\text { Bacamarte }\end{array}$ & PB/Brasil & -35.671389 & -7.259722 \\
\hline Ouricuri & PE/Brasil & -39.983333 & -7.983333 \\
\hline
\end{tabular}




\begin{tabular}{|l|l|l|l|}
\hline Petrolina & PE/Brasil & -40.500000 & -9.416667 \\
\hline Petrolina & PE/Brasil & -40.533333 & -9.383333 \\
\hline Cianorte & PR/Brasil & -52.483333 & -23.650000 \\
\hline Sengés 1 & PR/Brasil & -49.483333 & -24.083333 \\
\hline Sengés 2 & PR/Brasil & -49.383333 & -24.116667 \\
\hline Tibagi & PR/Brasil & -50.415278 & -24.513611 \\
\hline Caçapava do Sul & RS/Brasil & -53.333056 & -30.748889 \\
\hline Capão da Canoa 1 & RS/Brasil & -50.047500 & -29.758611 \\
\hline Capão da Canoa 2 & RS/Brasil & -49.933333 & -29.633333 \\
\hline Cruz Alta 1 & RS/Brasil & -53.605833 & -28.627778 \\
\hline Cruz Alta 2 & RS/Brasil & -53.614722 & -28.569722 \\
\hline Iara Maria & RS/Brasil & -54.716667 & -29.416667 \\
\hline Osório 1 & RS/Brasil & -50.216667 & -29.916667 \\
\hline Osório 2 & RS/Brasil & -50.166667 & -29.883333 \\
\hline Santiago & RS/Brasil & -54.833333 & -29.183333 \\
\hline São Francisco de & RS/Brasil & -55.083333 & -29.500000 \\
Assis & & & \\
\hline Torres & RS/Brasil & -49.750000 & -29.345556 \\
\hline Barra da Lagoa & SC/Brasil & -48.421111 & -27.573333 \\
\hline Joinville & SC/Brasil & -48.916667 & -26.183333 \\
\hline $\begin{array}{l}\text { São Francisco do } \\
\text { Sul }\end{array}$ & SC/Brasil & -48.533333 & -26.283333 \\
\hline Brotas & & & \\
\hline Cajuru & SP/Brasil & -47.950000 & -22.283333 \\
\hline Ibiuna & SP/Brasil & -47.266667 & -21.300000 \\
\hline Itatiba & SP/Brasil & -47.200000 & -23.733333 \\
\hline Itirapina & SP/Brasil & -46.838889 & -23.005833 \\
\hline Jundiaí & SP/Brasil & -47.800000 & -22.266667 \\
\hline Piracicaba & SP/Brasil & -46.950000 & -23.233333 \\
\hline $\begin{array}{l}\text { Santa Maria da } \\
\text { Serra }\end{array}$ & SP/Brasil & -47.683333 & -22.716667 \\
\hline São Simão & SP/Brasil & -48.200000 & -22.566667 \\
\hline Serrana & & \\
\hline Sertãozinho & -47.550000 & -21.466667 \\
\hline Sorocaba & -47.583333 & -21.216667 \\
\hline & SP/Brasil & -47.966667 & -21.150000 \\
\hline
\end{tabular}




\begin{tabular}{|c|c|c|c|}
\hline Haplótipo & Localidade & Domínio & $\begin{array}{l}\text { Número de } \\
\text { indivíduos }\end{array}$ \\
\hline \multirow[t]{36}{*}{ Haplótipo 1} & San Luis & Chaco & 4 \\
\hline & La Cruz & Chaco & 3 \\
\hline & Vale Fertil & Chaco & 1 \\
\hline & Cordoba & Chaco & 1 \\
\hline & San Raphael & Chaco & 1 \\
\hline & San Juan & Chaco & 1 \\
\hline & Cochabamba & Chaco & 2 \\
\hline & Capão da Canoa & Floresta Atlântica & 1 \\
\hline & Tramandaí & Floresta Atlântica & 3 \\
\hline & Arroio Teixeira & Floresta Atlântica & 4 \\
\hline & Sengés & Floresta Atlântica & 5 \\
\hline & Tibagi & Floresta Atlântica & 1 \\
\hline & Osório & Floresta Atlântica & 5 \\
\hline & Ibiúna & Floresta Atlântica & 1 \\
\hline & Sorocaba & Floresta Atlântica & 1 \\
\hline & Itirapina & Floresta Atlântica & 1 \\
\hline & Piracicaba & Floresta Atlântica & 1 \\
\hline & Serra do Japi & Floresta Atlântica & 1 \\
\hline & Guaritas & Pampas & 1 \\
\hline & Santiago & Pampas & 10 \\
\hline & Furnas & Cerrado & 4 \\
\hline & Sertãozinho & Cerrado & 1 \\
\hline & Altinópolis & Cerrado & 1 \\
\hline & Cajuru & Cerrado & 1 \\
\hline & Chapéu MG & Cerrado & 1 \\
\hline & Estreito & Cerrado & 1 \\
\hline & São Simão & Cerrado & 1 \\
\hline & Nova Ponte & Cerrado & 6 \\
\hline & Cardeal Mota & Cerrado & 2 \\
\hline & Ibotirama & Caatinga & 3 \\
\hline & Manoel Vitorino & Caatinga & 3 \\
\hline & Morro Torre & Caatinga & 1 \\
\hline & Chapeu BA & Caatinga & 1 \\
\hline & Irece & Caatinga & 2 \\
\hline & Xique-xique & Caatinga & 1 \\
\hline & Exu & Caatinga & 1 \\
\hline Haplótipo 2 & La Cruz & Chaco & 1 \\
\hline Haplótipo 3 & Vale Fertil & Chaco & 1 \\
\hline Haplótipo 4 & Vale Fertil & Chaco & 1 \\
\hline Haplótipo 5 & La Cruz & Chaco & 1 \\
\hline & Tramandaí & Floresta Atlântica & 1 \\
\hline Haplótipo 6 & San Juan & Chaco & 1 \\
\hline Haplótipo 7 & San Juan & Chaco & 1 \\
\hline Haplótipo 8 & Santiago & Pampas & 1 \\
\hline Haplótipo 9 & Chapéu MG & Cerrado & 1 \\
\hline
\end{tabular}




\begin{tabular}{|c|c|c|c|}
\hline Haplótipo 10 & Chapéu MG & Cerrado & 1 \\
\hline Haplótipo 11 & Guaritas & Pampas & 1 \\
\hline Haplótipo 12 & Guaritas & Pampas & 1 \\
\hline Haplótipo 13 & Sengés & Floresta Atlântica & 1 \\
\hline Haplótipo 14 & Arroio Teixeira & Floresta Atlântica & 1 \\
\hline Haplótipo 15 & Tramandaí & Floresta Atlântica & 1 \\
\hline Haplótipo 16 & Sengés & Floresta Atlântica & 1 \\
\hline Haplótipo 17 & Sorocaba & Floresta Atlântica & 1 \\
\hline Haplótipo 18 & Itatiba & Floresta Atlântica & 1 \\
\hline \multirow[t]{3}{*}{ Haplótipo 19} & Nova Ponte & Cerrado & 1 \\
\hline & Furnas & Cerrado & 1 \\
\hline & Salvador & $\begin{array}{l}\text { Floresta Atlântica } \\
\text { NE }\end{array}$ & 2 \\
\hline \multirow[t]{2}{*}{ Haplótipo 20} & Altinópolis & Cerrado & 2 \\
\hline & Itirapina & Floresta Atlântica & 1 \\
\hline Haplótipo 21 & Itirapina & Floresta Atlântica & 1 \\
\hline Haplótipo 22 & Sertãozinho & Cerrado & 1 \\
\hline Haplótipo 23 & Cajuru & Cerrado & 1 \\
\hline \multirow[t]{2}{*}{ Haplótipo 24} & Ibotirama & Caatinga & 1 \\
\hline & Exu & Caatinga & 2 \\
\hline Haplótipo 25 & Chapéu BA & Caatinga & 1 \\
\hline \multirow[t]{7}{*}{ Haplótipo 26} & Brotas & Cerrado & 1 \\
\hline & Morro Torre & Caatinga & 3 \\
\hline & Xique-xique & Caatinga & 1 \\
\hline & Juazeiro & Caatinga & 1 \\
\hline & Exu & Caatinga & 1 \\
\hline & Campina Grande & Caatinga & 1 \\
\hline & Junco do Seridó & Caatinga & 1 \\
\hline Haplótipo 27 & Piracicaba & Floresta Atlântica & 1 \\
\hline Haplótipo 28 & Juazeiro & Caatinga & 1 \\
\hline Haplótipo 29 & Juazeiro & Caatinga & 1 \\
\hline Haplótipo 30 & Manoel Vitorino & Caatinga & 1 \\
\hline \multirow[t]{2}{*}{ Haplótipo 31} & Milagres & Caatinga & 1 \\
\hline & Campina Grande & Caatinga & 1 \\
\hline Haplótipo 32 & Milagres & Caatinga & 1 \\
\hline Haplótipo 33 & Campina Grande & Caatinga & 1 \\
\hline Haplótipo 34 & Barra da Lagoa & Floresta Atlântica & 1 \\
\hline Haplotipo 35 & Juazeiro & Caatinga & 1 \\
\hline Haplótipo 36 & Milagres & Caatinga & 1 \\
\hline
\end{tabular}




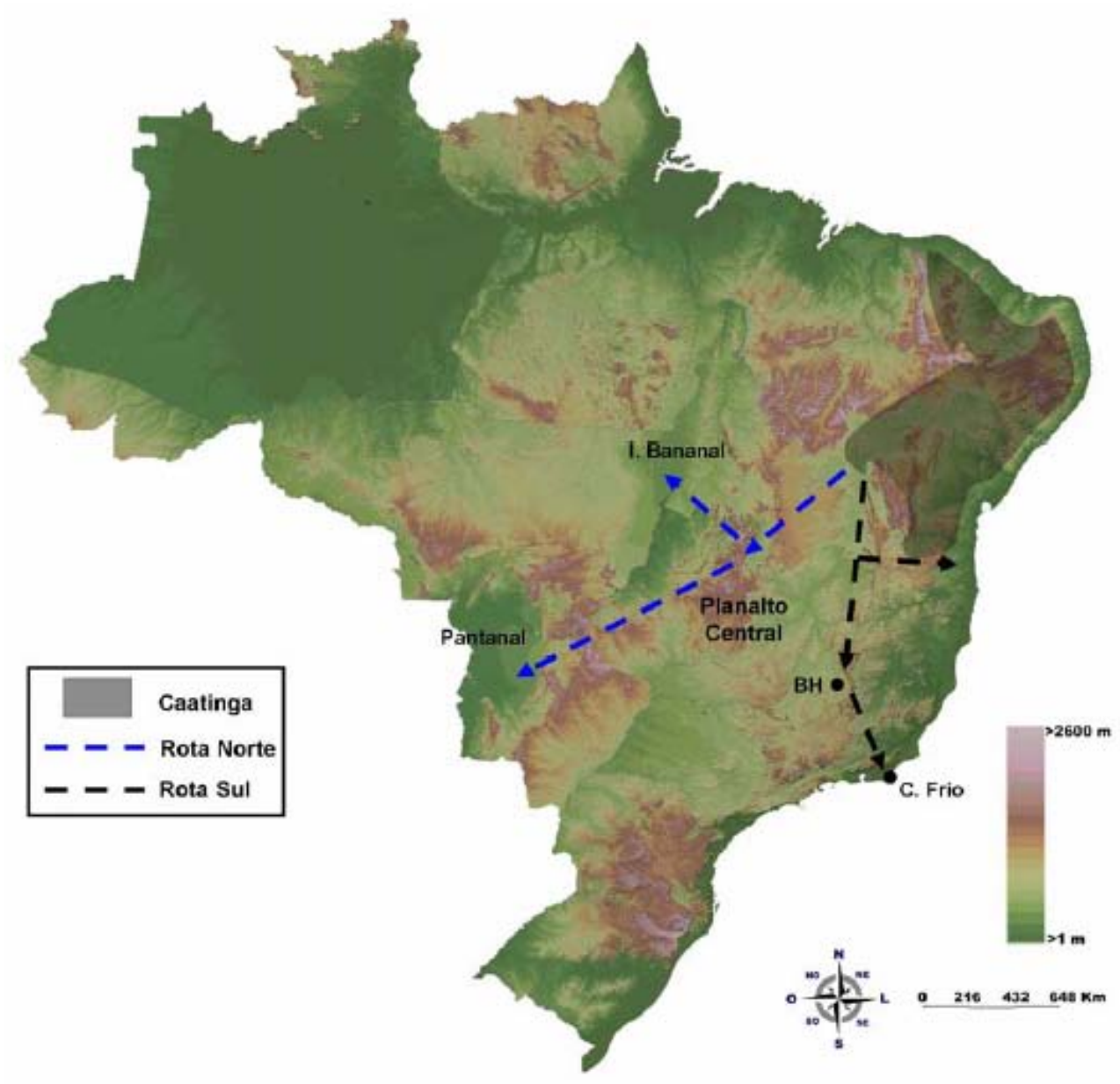

Figura 19. Mapa topográfico do Brasil, retirado de Franco et al (2009). A área sombreada representa a área de ocorrência aproximada atual da Caatinga. Setas tracejadas azuis e pretas representam, respectivamente, as rotas norte e sul propostas para explicar a expansão da vegetação da Caatinga durante os períodos de mais secos do Pleistoceno, na América do Sul (Prado e Gibbs, 1993; Prado, 2000). BH: cidade de Belo Horizonte, MG; C. Frio: cidade de Cabo Frio, RJ. 


\title{
Dispersion Routes of Drosophila buzzatii (Diptara: Drosophilidae) in South America.
}

\author{
Authors: Mateus Henrique Santos ${ }^{1}$, Maura Helena Manfrin ${ }^{2}$ \\ ${ }^{1}$ Universidade de São Paulo, Faculdade de Medicina de Ribeirão Preto - SP - Brazil \\ ${ }^{2}$ Universidade de São Paulo, Faculdade de Filosofia, Ciências e Letras de Ribeirão \\ Preto - SP - Brazil \\ ${ }^{1}$ mateushenrique@yahoo.com.br
}

Keywords: Drosophila buzzatii, Dispersion routes, Phylogeography, mitochondrial DNA, paleomodeling.

\section{Abstract}

The fruit-fly Drosophila buzzatii is a cactophilic species in association with cactus species distributed along the Phytogeographic Domains of Caatinga, Cerrado, Atlantic Forest, Pampas and Chaco. Based in the diversity of chromosomal inversion and populational density of the species, the Chaco Domain was considered the "Center of Origin” of the D. buzzatii. However, recent works, using allozymes and DNAmt, showed a possible origin of the $D$. buzzatii in the Caatinga. The objectives of this work were trace historical dispersion routes of $D$. buzzatii, current and ancient areas of distribution in the South America. We obtained DNA sequences in 132 samples in 44 localities with 714 bp length from the COI mtDNA gene, generating 36 haplotypes. The diversity indexes, AMOVA, neutrality tests, Mismatch Distribution, Baesyan Skyline Plot, NCPA and sense of migration movements was calculated, to describe part of the evolutionary history of the species. The nucleotide diversity was 0,0030 - Caatinga, 0,0019 - Mata Atlântica, 0,0020 - Cerrado, 0,0011 - Pampas and 0,0004 - Chaco. The AMOVA results, grouped by Domain showed that $68,33 \%$ of the variation is intrapopulation and a significant portion of the variation is due to inter-regional differences $(\Phi c t=0,07124 \mathrm{p}=0,00196)$. The Neutrality tests (Tajima's $\mathrm{D}=-2,4150, \mathrm{p}=0,0317$ and Fu's Fs $=-28,6719, \mathrm{p}=0,00001)$, the star-shape of the haplotype network, and Mismatch Distribution showed population expansion signs, estimated in 494.257,3 ybp, according Rogers and Harpending model (1992). However, the BSP showed that the movement is ancient, estimated in $550.000-650.000$ ybp. The NCPA showed restricted 
gene flow with isolation by distance, confirmed by the Mantel Test and some long distance dispersion. The results of the program Migrate N showed a complex pattern of migration between the domains, but a north/south pattern could be identified. The genetic structure can be explained to the widespread distribution of the species, that could generate isolation by distance and by the presence of geographic and climatic barriers (between Cerrado and Caatinga domains) and in the States of Rio de Janeiro and Espírito Santo (along the Atlantic Forest) when there is none or few individuals of the species $D$. buzzatii. The expansion movements occurred in the Quaternary Period during glaciations events in the Illinoian and their subdivisions, due to the decrease of the global moisture that generated favorable conditions to the expansion of the dry vegetation and associated species. Based on the results of this work it was possible to delineate many migration routes between the phytogeographic domains, and the more ancient movement started in the Caatinga and this result not support the hypothesis that Chaco was the "Center of Origin" from D. buzzatii

\section{Introduction}

Many efforts have been devoted to studying the genetic consequences of the climatic changes, especially during the glaciations of the Pleistocene in Northern Hemisphere species (Hewitt 2004). Studies have focus on the investigation of the geographical distribution of gene lineages showing significant results to the past climatic changes in shaping the history and population structure of terrestrial species. However, few works had focus in the dispersion routes adopted by the species during these climatic changes, and comparatively much less attention has been given to the Pleistocene climatic changes effects in the species of South America, especially in the dry areas of South America and eastern Brazil in particular (Carnaval and Moritz 2008). These areas encompass large dry forest crossing the north-eastern of Brazil to Argentina and include the Caatinga domain in north-eastern of Brazil, the Cerrado in the central and south-western portion of Brazil and the Chaco in Argentina, Paraguay and Bolivia. The Caatinga vegetation is composed of xerophytic plants and a high density and diversity of cacti species that survive in a semiarid climate, but the Cerrado vegetation is dominated by a semi-deciduous savanna with enclaves of rock outcrops called "Campos Rupestres" that show favorable conditions to cactus development (Da Silva and Bates 2002). The Chaco domain has xeric vegetation in the southernmost portion of 
the South America and extends through Argentina, Bolivia and Paraguay to the eastern slopes of the Andes. Besides, cactus vegetation is found along all the east coast of South America on the rock and sand dunes.

The dry vegetation showed a more widespread distribution during the glaciations periods of the Pleistocene, including the coastal cactus vegetation (Ab'Saber 1982; Bigarella et al. 1982; Prado and Gibbs 1993; Pennington et al. 2000; Behling et al. 2007) because during the Pleistocene, the Neotropics experienced climatic fluctuations, with cooler conditions and longer dry seasons than today in some regions (Behling and Lima da Costa 2001; Mayle et al. 2004; Ledru et al. 2005) that favored the expansion of species associated with these climatic condition (Behling 2002; Ledru et al. 2006; Werneck and Colli 2006; Behling et al. 2007; Safford 2007; Caetano et al. 2008; Carnaval and Moritz 2008). Species associated with xeric habitats may have experienced recurrent shifts in their distribution, with population mixing, isolation, genetic structure and routes of migration that follow these movements of expansion and contraction.

The Drosophila buzzatii species is a cactophilic fruit-flies member of the repleta group and has a broad geographic distribution in South America and is found in territories such as Argentina, Bolivia, Paraguay and Brazil (Pereira et al. 1983; Vilela 1983; Figueiredo and Sene 1992), but recently invaded Europe and Australia (Fontdevila et al. 1981; Barker et al. 1985). The D. buzzatii live and reproduce in various hosts cactus species, principally in the genera Opuntia, Cereus, Trichocereus and Pilosocereus (Manfrin and Sene 2006). The distribution of these genera of cactus vary substantially along the South America, but are found in high density in two main arid Domains: the Chaco in Northern Argentina and east Bolivia and the Caatinga in Northeast Brazil, areas which are thought to have been connected during the Pleistocene (Prado and Gibbs 1993; Prado 2000). Cacti are not as frequent in other areas, being mostly found in rocky outcrops or in sandy substrates associated with dry deciduous forest.

Natural populations of $D$. buzzatii have been extensively studied in South America, Spain and Australia (Fontdevila et al. 1981; Barker et al. 1985; Betrán et al. 1998) and these studies have indicated little population substructure and high levels of gene flow (Thomas and Barker 1990; Rossi et al. 1996; De Brito et al. 2002), the exception is the detection of private allozyme alleles in Northeastern Brazil (Barker et al. 1985) and the fact that brazilian populations of $D$ buzzatii showed $50 \%$ more 
polymorphism in the mtDNA than Argentinean populations (De Brito, Manfrin, and Sene 2002; Manfrin and Sene 2006). Although D. buzzatii is very common in Argentinean Chaco showing high density and high level of chromosomal inversion polymorphism, suggesting that $D$. buzzatii was originated from the Argentinean Chaco and expanded its area of occurrence towards the northeast of Brazil (Carson and Wasserman 1965; Vilela et al. 1980; Figueiredo and Sene 1992). However, the observation of high diversity of nucleotides and most divergent haplotypes in the northeast populations of Brazil are in conflict with the hypothesis of recent expansion towards the northeast of Brazil from Chaco populations and the concept of a center of origin in Chaco domain must be revised (De Brito, Manfrin, and Sene 2002).

The works of De Brito et al. (2002) showed that D. buzzatii was presented in the northeast of Brazil more than 100.000 years before present confirming natural dispersion of the specie along your distribution; however the route followed by the species was not mensurated. According Prado and Gibbs (1993) and Prado (2000) a north/south vegetation route along the Parana-Paraguay river occurred to the vegetation of the Caatinga domain and this pattern seems to be followed by some fruit-fly species (Moraes et al. 2009). With the absence of dispersion routes suggested and the indications of conflicts in the center of origin by $D$. buzzatii this work used recent statistical and genetic analyses, to suggest possible dispersion routes, time of expansion, genetic structure and area of distribution current and ancient of $D$. buzzatii along the South America.

\section{Material and Methods}

\section{Samples and Genetic Analysis}

One hundred and thirty two male Drosophila buzzatii were sampled along their distribution area from Northeast of Brazil to Argentina (Fig. 1). All the individuals analyzed was collected in natural environments (wild-caught flies) using traps with a mix of banana, orange and the Sacharomices cerevisae, and stocked in ethanol $70 \%$ solution. The species identification occurred in the laboratory by analysis of the male aedeagus morphology (Vilela et al. 1983). The DNA extraction was performed using the Wizard Genomics DNA Purification Kit (Promega), following the instruction from the manufacturer's protocol. The COI gene fragment from mtDNA was amplified using 
the primers 1406f and 2191r (De Brito, Manfrin, and Sene 2002). All samples was amplified by polymerase chain reaction (PCR) in a final volume of $20 \mu \mathrm{l}$ using 2,0 mM $\mathrm{MgCl}^{+}$buffer, 0,2 $\mathrm{nmol} / \mu \mathrm{l} \mathrm{dNTPs}, 4 \mathrm{mM}$ each primer and 0,14 $\mu \mathrm{l}$ Taq polymerase (5U/ $\mu \mathrm{l})$ The reaction mix was submitted to the following cycling program: one step of $1^{\prime} 30^{\prime \prime}$ at $94^{\circ} \mathrm{C}, 30$ cycles of $40^{\prime \prime}$ at $94^{\circ} \mathrm{C}, 40^{\prime \prime}$ at $47^{\circ} \mathrm{C}$ and $2^{\prime}$ at $72^{\circ} \mathrm{C}$, and a final extension of $10^{\prime}$ at $72^{\circ} \mathrm{C}$. The PCR products were purified by incubating 5-7 $\mu$ l of PCR product with 1,5 - 2,6 $\mu \mathrm{l}$ of shrimp alkaline phosphatase and exonuclease I (Exo-SAP; Pharmacia) at $37{ }^{\circ} \mathrm{C}$ for $15 \mathrm{~min}$ followed by $15 \mathrm{~min}$ at $80{ }^{\circ} \mathrm{C}$ (Modified from Werle et al. 1994). The Purified PCR product was prepared for sequencing according to the BigDye Terminator Cycle Sequencing Ready Reaction Kit (Perkin-Elmer) manual. Automatic DNA sequencing was performed on an ABI Prism ${ }^{\mathrm{TM}} 377$ (Perkin- Elmer) sequencer.

\section{Statistical Analysis}

Sequences were checked by eye using the program Chromas Lite 2.0, a freeware program (http://www.technelysium.com.au/chromas_lite.html) and aligned using the Bioedit version 7.0.9 program (Hall 1999) and Clustal W v. 1.8 (Thompson et al. 1994). To describe the amount of genetic variation in a population, we calculated haplotype diversity (h) and nucleotide diversity $(\pi)$ (Nei 1987) and their standard deviations (s), using the program Arlequin version 3.01 (Excoffier et al. 2005). The existence of population genetic differentiation was tested using the AMOVA test (Excoffier et al. 1992), which uses a conventional F-statistic based on analysis of variance in genetic frequencies. AMOVA was performed by grouping samples according to geographic location of samples in relation of the correlated Domains. We first used a global AMOVA, with no separation of localities or region units, and then performed tests with hierarchical groups in relation of the Domains of the samples (Caatinga, Cerrado, Atlantic Forest, Pampa and Chaco).

We performed several statistical tests that permit inferences about a number of events that could cause deviations from neutrality: Fu's Fs (Yun-xin 1997) and Tajima’s D (Tajima 1989) tests implemented in Arlequin, and Fu and Li's F* and $\mathrm{D}^{*}$ statistics (Fu and Li 1993) using DnaSP version 5.0 (Librado and Rozas 2009). Fu's Fs values have been shown to be more sensitive to departures from demographic equilibrium due to population expansion and selective sweep (Yun-xin 1997), while Tajima’s D exhibits 
significantly positive deviations generally caused by population bottlenecks and significantly negative values due to expansions (Aris-Brosou and Excoffier 1996). Fu and Li's $\mathrm{F}^{*}$ and $\mathrm{D}^{*}$ tests are more sensitive to background selection than Fs, and they do not present significant deviations from neutrality due to historic expansion (Yun-xin 1997). The Mismatch distribution, which measures the differences between sequence pairs, was estimated as an additional test for demographic expansion (Rogers and Harpending 1992). Pairwise differences present a multimodal distribution in samples of populations that are in demographic equilibrium, but generally a unimodal distribution in samples of populations that underwent recent demographic expansion (Rogers and Harpending 1992; Schneider and Excoffier 1999). Fit between the observed and expected distributions was evaluated by the sum of square deviations (SSD) (Schneider and Excoffier 1999). We performed a model selection test in the program Mega v. 5.0. (Tamura et al. 2007) to find the best model of substitution to use in the analyses.

Nested clade phylogeographical analyses (NCPA) (Templeton et al. 1995) was used to investigate the evolutionary processes responsible for the observed genetic structure patterns in the mtDNA fragment analyzed. Aligned DNA sequences were put into the TCS program v. 1.13 (Clement et al. 2000) to generate a haplotype network. The nested clade was performed by hand, according Templeton (1998). The GeoDis program (Posada et al. 2000) was used to test for significant association between the nested clade design from haplotype network and the geographic distances between sampled colonies. The inference key from Templeton (2004) was used to infer the historical events in the significant results from GeoDis program. Since 2007, many works have criticized and defended the valid use of the NCPA and the isolation by distance was showed the most common erroneous results generated by these analyses. To minimize the effect of these erroneous results, we performed the Mantel test (Mantel 1967; Smouse et al. 1986). in the Arlequin program, to confirm probably isolation by distance events in the analyses. The Mantel test was performed using the Fst values and the geographical distance in kilometers to construct and compare the values.

The demographic parameters describing population expansion were obtained from mismatch analysis through estimation of the age of expansion $(\tau)$ and population sizes before $\left(\theta_{0}\right)$ and after $\left(\theta_{1}\right)$ the expansion in units of mutational time, using the Arlequin program. Possible population expansion events detected by the statistical programs, described above, was dated by the Rogers and Harpending model (1992) that was used to estimate the time in years since population expansion, using the equation $t$ 
$=\tau / 2 \mathrm{u}$, where $\mathrm{u}$ is the mutation rate per sequence per generation and additionally dated by the Bayesian Skyline Plot (BSP) using the base substitution model HKY, calculated by the program Mega 5.0 (Tamura et al. 2007), a bayesian method that estimate the variation in the effective size of population through time (Drummond et al. 2005). The BSP analysis was calculated using the Beast program v 1.5.4 (Drummond and Rambaut 2007). The t values were calculated using $714 \mathrm{bp}$, a generation time of ten generation a year (Moraes et al. 2009) and a mutation rate of $4.45 \times 10^{-7}$ mutations per sequence per generation. This mutation rate was obtained by comparison between the COI gene from D. melanogaster and D. yakuba, that diverged to approximately 6.1 million years (Russo et al. 1995; Nagaraju and Ranganath 2004).

To estimate the direction of migration movements we used the program Migrate N 3.1.6 (Beerli and Felsenstein 1999, 2001; Beerli 2006). This program calculates the number of migration per generation from one group to another and viceversa. We performed these test a priori without a geofile and a posteriori with a geofile, when we calculated the average geographic center point of any Domain and the pairwise distance in kilometers between all Domains.

\section{Ecological niche modeling}

To understand some movements in the glaciations periods we used ecological niche modeling approach to recreate some conditions for the $D$. buzzatii species in an environment dryer than today and probably more adequate for the species expansion. We used estimations from the last glaciations maximum with present conditions to compare the distribution in those two scenarios. The maximum entropy algorithm implemented in the MAXENT program (Phillips et al. 2006) was used to modeling the presence maps. The points used for these analyses are listed in table 1 . The current distribution was estimated using maps with spatial resolution of $1 \mathrm{~km}$ and the follow bioclimatic conditions plus altitude layer: mean diurnal range, temperature seasonality, maximum temperature of warmest month, minimum temperature of coldest month, temperature annual range, annual precipitation, precipitation seasonality, precipitation of wettest quarter, precipitation of warmest quarter (Hijmans et al. 2005; Thomé et al. 2010), precipitation of driest quarter and precipitation of coldest quarter. We used the "dontextrapolate" function in the MAXENT program to avoid spurious projections (Giovanelli et al. 2008; Thomé et al. 2010). We used the minimum presence 
criterion for the threshold definition that is equal the minimum model prediction value for any occurrence data and the probabilities below the threshold value were transformed to zero and a binary map were produced. The model accuracy was checked using $75 \%$ of the data like training data and $25 \%$ like test data for model validation. Evaluation of the model resulting was made by the underlying area (AUC) (Fielding and Bell 1997; Manel et al. 2001), that ranges from 0.5 (random accuracy) to a maximum value of 1.0 (perfect discrimination). To test expansion movements we tested the current time model to two paleoclimate scenarios, simulating the last glacial maximum period (LGM) 21.000 years ago: CCSM and MIROC (both available at: http://www.worldclim.org/past). The settings, threshold and background for the past projections were the same used for current time modeling with the exception of the altitude layers that was not used for past simulations one time that the sea level in these conditions are not the same.

\section{Results}

A 714 bp fragment from the COI gene was sequenced in 134 individuals from 44 localities along the distribution of the species from Northeast of the Brazil (Caatinga Domain) to Argentina and Bolivia (Chaco Domain) (Fig. 1). We found a total of 36 haplotypes, described by 41 variable sites and base proportions of $\mathrm{C}=17,12 \%, \mathrm{~T}=$ 37,44\%, $\mathrm{A}=28,76 \%$, and $\mathrm{G}=16,69 \%$. The most frequent haplotype "Hap01" were found in all Domains, accounting for 58,95\% and the second more frequent haplotype "Hap25”, only in the Caatinga and Cerrado Domains with frequency of 6,71\%. Results from Mega v. 5.0. program showed that the substitution models HKY and Tamura-Nei was the best substitution models to be used in the further analyses and we used those models when necessary. The highest levels of nucleotide diversity were found in the samples from the Caatinga Domain $(\pi=0,002946, \mathrm{~s}=0,001999)$ and a decreasing cline north/south followed by Cerrado, Atlantic Forest, Pampa and Chaco (table 2). The Caatinga Domain showed the highest number of private haplotypes -10 , followed by Atlantic Forest - 8, Chaco - 5, Cerrado - 4 and Pampas - 3. Results from AMOVA provided evidence that $64,04 \%$ of the variation was found within populations (table 3 ) and the Fst results showed that Caatinga Domain is genetic structured with significant values of Fst among all other Domains and Atlantic Forest NE has genetic structure among Chaco, Pampas, Cerrado and Caatinga (table 4). 
Significantly large negative Fu’s Fs $(-28,6719, \mathrm{p}=0,0000)$ and Tajima’s D ($2,4150, \mathrm{p}=0,001$ ) values rejected populations stasis/neutrality and further indicate an excess of recent mutations. We compared the results of Fu's Fs and Tajima's D for all Domains, in separate, with the results of $\mathrm{D}^{*}$ and $\mathrm{F}^{*}$ one time that significant and negative values of Fu's Fs and Tajima's D against not significant values of $\mathrm{D}^{*}$ and $\mathrm{F}^{*}$ indicate expansion (Peck and Congdon 2004). From this comparison we found that only the Domains Caatinga, Cerrado and Chaco showed the conditions described above and suffered expansion movement (table 2). The mismatch distribution analysis presented a curve adjusted to the model of population growth tested for the total sample, but when tested in any separated Domain, only the Atlantic Forest don't showed the unimodal curve expected from a population in an expansion process (Fig. 2).

The haplotype network showed a star-shape form that according Avise (2000) is an indication of a population expansion process. We performed a NCPA analyses (Fig. 3) and found three separated clades. The ancestral haplotype "Hap01" was found in the clade 2-1 and all the Domains has this haplotype with the exception of the Atlantic Forest NE that only has the haplotype 18 "Hap18" shared with the Cerrado Domain in the localities of Nova Ponte and Furnas on Minas Gerais State in the geographic center of the species distribution. The other two clades are almost formed by samples of the Caatinga Domain with the exceptions of one sample of the Cerrado, two from Atlantic Forest and one from Chaco. Evolutionary events found by this analysis were expansion and long distance colonization and restricted gene flow with isolation by distance or past gene flow with extinction in some areas and the results are summarized in the table 5 .

To estimate the time of the expansion event we use the Bayesian Skyline Plot and the Mismatch distribution, according Rogers and Harpending (1992). The Mismatch analysis was based on the values of tau $(\tau)$ performed in the Arlequin program with 95\% of confidence. The BSP was performed with all samples and separated for all Domains and the global results showed a constant growth with an increase in the population size around 550.000 - 600.000 years before present (Fig. 4) and by the Mismatch distribution, that the expansion time occurred 494.269,70 (confidence interval 95\%) before present. The tests for any Domain are showed in Figure 5, and indicated that, according to BSP analyses, the Caatinga Domain was the ancient one, and the expansion occurred 510.000 years ago followed by Atlantic forest 295.000; Chaco - 270.000; Cerrado - 240.000 and Pampas - 190.000. The results from 
Mismatch distribution showed that the ancient expansion occurred in the Cerrado Domain - 297.357, followed by Caatinga - 288.798, Chaco - 122.453, Pampas 35.112 and Atlantic Forest - 27.431 years ago.

Using the Migrate $\mathrm{N}$ program we found that the Caatinga Domain donate migrants for the Atlantic Forest NE, receiving migrants from the Cerrado and Atlantic Forest NE. The Cerrado Domain donate for Caatinga, Atlantic Forest NE and Pampas in the Southern distribution of the Brazil, receiving migrants from both Atlantic Forest regions, but the Atlantic Forest only donate migrants for Cerrado and Chaco, receiving migrants from the Chaco Domain. The Pampas only donate from Atlantic Forest NE, receiving from Cerrado and Chaco and finally the Chaco that donate for Atlantic Forest and Pampas, receiving from Atlantic Forest (table 6).

The AUC showed high values to current - 0,911, CCSM - 0,912, MIROC 0,900 , and indicates that the distribution model tested performed better than a random model. Predictive maps (Fig 6, 7 and 8.) were generated after a minimum presence threshold of 0,10. The current time model predicted an area compatible with the current distribution of the species and two areas when it is not naturally found, along the countries of Peru and Chile. The current time model, the MIROC-LGM and CCSMLGM projections showed similar results, but the LGM projections showed along the Brazilian and Uruguay coast an area under the current sea level making a corridor like area, more contiguous in the MIROC-LGM projections. This projection also showed an area of presence in the Ecuador and in south of Chile. Already the CCSM-LGM projections showed a narrow corridor along the Cordillera of Andes connecting the Peru with the actual Chaco distribution. The three projections showed in general a huge connective area of probability of the species distribution along the South America, what is expected for the $D$. buzzatii species.

\section{Discussion}

The hypothesis that the center of origin of $D$. buzzatii is the Chaco Domain was originally proposed based in the fact that the populations of $D$. buzzatii in the Argentina has three kinds of chromosomal inversions (Carson and Wasserman 1965). Additionally to this, the work of Vilela and Sene (1980) showed a huge concentration of D. buzzatii in the Chaco reinforcing this idea and, according Figueiredo and Sene (1992) the low chromosomal variability found in the Brazilian populations reflects a loss of variability along the dispersion routes and are considered ecologically marginal. However, the 
work of De Brito et al. (2002) found high polymorphisms of the mtDNA in the Caatinga populations and the presence of private allozyme alleles in the Northeast region of the Brazil (Barker et al. 1985) raise a doubt about the center of origin proposed by the other authors. The results of the present work, using mtDNA showed a cline in the diversity from northeast to south of the natural distribution of D. buzzatii in South America. Also the estimations of expansion times showed that the more ancient expansion movement started from the Caatinga Domain and not from Chaco, reinforcing the idea proposed by De Brito et al. (2002) that the center of origin was not be the Chaco. The high density found in the Chaco by Vilela et al. (1980) could be a result of a well succeed colonization of a new area with no or few predators and competitors, and full of new resources to be colonized, one time that in the Caatinga, there are other four sister species of Drosophilids that potentially can use the same resources of $D$. buzzatii, in contrast to the Chaco that has only $D$. koepferae that uses the same resources that $D$. buzzatii (Manfrin and Sene 2006). An increase in the samples and tests for chromosomal inversions must be done in the Caatinga area to confirm the previously idea of the center of origin. We are not saying that the center of origin is the Caatinga Domain but the mtDNA showed that the expansion movements started from the Caatinga and we have no data to measure when the ancestral of $D$. buzzatii became this species and your first distribution.

The BSP analyses showed that the increase in the population size of $D$. buzzatii occurred more than 550.000 years ago (Fig. 5) and the Caatinga expansion occurred 510.000 (Fig. 5). According with the work of Gibbard and Kohen (2008) (data to 2010 found in: http://www.quaternary.stratigraphy.org.uk/correlation/chart.html) we plot the results of the BSP and possible glaciations events and all the expansion movements are in accordance with one of these periods. During the glaciations events, the south hemisphere become more dry and cold, with the exception of parts of Patagonia (Zeisset and Beebee 2008), there are no significant increase in the glaciers, but the environmental conditions changed. These dry conditions provided good condition to the expansion of the xeric vegetation, like the Cerrado, Caatinga and Chaco, replacing the mesophilic vegetation like the Amazonian and Atlantic forest (Haffer 1969; Vanzolini and Williams 1970). Comparisons of the neutrality tests showed that these three Domains showed expansion signals (table 2 and Fig. 5). Many works with geomorphology (Ab’Saber 1977; Wang et al. 2004), palinologic (Behling and Lichte 1997; Behling 2002; Ledru, Rousseau, and Cruz 2005; Ledru et al. 2006), 
paleomodeling (Mayle et al. 2004; Carnaval and Bates 2007), phyto and phylogeographic (Pennington, Prado, and Pendry 2000; Taylor and Zappi 2004; Carnaval and Bates 2007; Moraes et al. 2009), give support to the idea of cyclic fluctuations in the temperature and moisture in the South America, changing the vegetation and the landscape.

According with the results of the Migrate $\mathrm{N}$ and BSP together we could estimated the sense and movements chronology of $D$. buzatii. The first expansion movement occurred 510.000 years ago from Caatinga to the Atlantic Forest, during the Pre-illinoian D period (Fig. 5). This time of expansion is closer to the values estimated by $D$. gouveae - 450.000 years ago (Moraes et al. 2009), a sister species belonging to the $D$. buzzatii Cluster. The second expansion occurred 295.000 years ago from the Atlantic Forest to the Cerrado and Chaco Domains, during the Pre-illinoian A period. The thirty movements occurred 270.000 years ago from Chaco to Pampas and back to the Altantic Forest in the Pre-illinoian A period. The fourth movement occurred from Cerrado to Caatinga 240.000 years ago and was in the same glaciations period of the second and thirty movements (Fig. 5). The fifth expansion occurred 190.000 years ago from the Pampa to Caatinga. Using the niche modeling to the last glaciations period (21.000 years ago) we found that was a high probability area of presence of $D$. buzzatii along the Brazil and Uruguay coast, an area when under the current sea level but in the last glaciations, because of the dry conditions, the sea level was lower than today and could be a dispersion corridor to the Pampa populations. This hypothesis is reinforced by the presence of the haplotype 34, from Barra da Lagoa, in the clade 2-3 when there is a predominance of haplotypes from Caatinga Domain and a lack of the species in the states of Rio de Janeiro and Espirito Santo, Brazil, when after many sample expeditions, we don't found the D. buzzatii in these areas. The past projections showed many connections between all Domains in the LGM, and if the conditions for the other glaciations events were similar to these projections, we can extrapolate these results to the other glaciations maximums and the connectivity between the Domains support the dispersion movements.

The AMOVA and Fst analyses of mtDNA revealed that the Caatinga Domain is genetic structured (see tables 3 and 4 ) and this could be due to the presence of some geographic barrier between these Domain with the others like the Atlantic Forest in the states of Espirito Santo and Rio de Janeiro. This region seems it was a moist region since in the glaciations periods (Thomé et al. 2010). The Caatinga is a very dry 
environment and has many species of cactus and could support a large population of $D$. buzzatii and other cactophilic species and this is a very important characteristic that differentiate it from the others Domains. The ecological niche modeling showed a corridor of high presence probability in the interior of the Serra do Mar in the northeast states of Brazil to Rio Grande do Sul and a very high probability in the Chaco region. But in the south of Bahia and north of Minas Gerais states there are an area with less than $50 \%$ of presence and could explain this pattern of isolation showed by the AMOVA and Fst analyses. This region is in a border of the climatic system, a transition region between two kinds of climatic environments that influence the characteristics of these two Domains and can to difficult the gene flow between Caatinga and other Domains. Using a high threshold of 0,6 (Fig. 9) for current projection, we found a pattern of distribution similar to those proposed by Prado (2000) for the Tropical Seasonal Forests Region of South America and even the doubt records of Prado in the Peru are similar to found in this work. According Brncic (1987) the D. buzzatii was found in Chile in a region very near to the predicted area projected in this work (Fig. 6) that confirm party of the predictions and according Ruiz, A. in a personal communication, the D. buzzatii species was found in the Peru, confirming party of the predicted distribution. The NCPA analyses showed isolation by distances in nearly all clades (table 5) and if we consider the huge range of distribution of the species $D$. buzzatii, it seems to be a plausible possibility. The NCPA was much criticized (Panchal and Beaumont 2007; Knowles 2008; Petit 2008; Nielsen and Beaumont 2009) and a cross validation with more than one gene was proposed with solution for the falsepositive results (Templeton 2009). Even working with one gene, we can test the isolation by distance results from the NCPA using the Mantel test (Mantel 1967; Smouse, Long, and Sokal 1986). The comparison between Fst (an index of genetic differentiation) with the geographic distance between samples if correlated can generate isolation by distance confirmation (correlation coefficient $-0.1261, \mathrm{p}-0.048$ ) and our results showed a correlation between the distance and the values of Fst and we can confirm the isolation by distance results from NCPA.

\section{Conclusions}

According with the results of this work, we can conclude that $D$. buzzatii:

1) Showed expansion movements in the Domains of the Caatinga, Cerrado and Chaco and the genetic diversity index and the BSP analyses showed 
that the more ancient movement begin in the Caatinga region approximately 510.000 years ago.

2) These movements followed a route north/south from Caatinga to Atlantic Forest, this for Chaco and Cerrado, back from Chaco to Atlantic Forest and to Pampas, from Cerrado to Caatinga and more recently from Pampas to Caatinga by a "undersea" route found in the glaciations maximums.

3) The Caatinga populations showed a genetic structure and low gene flow with the other Domains, result of a possible climatic barrier resulted from a climatic border system between Caatinga and other Domains.

\section{Acknowledgments}

Luiz Maestrelli Bizzo for the help support in the construction of the niche modeling projections; Dr. Fernando de Faria Franco for the support in the samples collections from the Paraíba state expedition; Dra. Nilce Maria Martinez Rossi for making available their laboratory to perform the sequencing reactions; Mendelson Mazucato for your essential assistance in the sequence; Dr. Reinaldo Antônio De Brito that kindly released some mtDNA sequences; Paulo Ricardo Epifanio for the laboratorial support;Dr. Fábio de Melo Sene for all the knowledge and intellectual support and to all other laboratory co-workers.

\section{References}

Ab'Saber, A. 1982. The paleoclimate and paleoecology of Brazilian Amazonia. Biological diversification in the tropics: Columbia University Press, New York.

Ab’Saber, A. 1977. Espaços ocupados pela expansão dos climas secos na América do Sul, por ocasião dos períodos glaciais quaternários. Paleoclimas 3:1-19.

Aris-Brosou, S. and Excoffier, L. 1996. The impact of population expansion and mutation rate heterogeneity on DNA sequence polymorphism. Molecular biology and evolution 13 (3):494.

Avise, J. 2000. Phylogeography: the history and formation of species: Harvard Univ Pr.

Barker, J. S. F., Sene, F. M., East, P. D., and Pereira, M. A. Q. R. 1985. Allozyme and chromosomal polymorphism of Drosophila buzzatii in Brazil and Argentina. Genética 67:161-170. 
Beerli, P. 2006. Comparison of Bayesian and maximum-likelihood inference of population genetic parameters. Bioinformatics 22 (3):341.

Beerli, P. and Felsenstein, J. 1999. Maximum-likelihood estimation of migration rates and effective population numbers in two populations using a coalescent approach. Genetics 152 (2):763.

Beerli, P. 2001. Maximum likelihood estimation of a migration matrix and effective population sizes in $\mathrm{n}$ subpopulations by using a coalescent approach. Proceedings of the National Academy of Sciences of the United States of America 98 (8):4563.

Behling, H. 2002. Late Quaternary vegetation and climate dynamics in southeastern Amazonia inferred from Lagoa da Confusao in Tocantins State, northern Brazil. Amazoniana 17 (1):27-39.

Behling, H., Dupont, L., DeForest Safford, H., and Wefer, G. 2007. Late Quaternary vegetation and climate dynamics in the Serra da Bocaina, southeastern Brazil. Quaternary International 161 (1):22-31.

Behling, H. and Lichte, M. 1997. Evidence of Dry and Cold Climatic Conditions at Glacial Times in Tropical Southeastern Brazil* 1. Quaternary Research 48 (3):348-358.

Behling, H. and Lima da Costa, M. 2001. Holocene vegetational and coastal environmental changes from the Lago Crispim record in northeastern Pará State, eastern Amazonia. Review of Palaeobotany and Palynology 114 (3-4):145-155.

Betrán, E., Santos, M., and Ruiz, A. 1998. Antagonistic pleiotropic effect of secondchromosome inversions on body size and early life-history traits in Drosophila buzzatii. Evolution 52 (1):144-154.

Bigarella, J., Andrade-Lima, D., and Prance, G. 1982. Biological diversification in the tropics: Columbia University Press New York.

Brncic, D. 1987. A review of the genus Drosophila Fallen (Diptera: Drosophilidae) in Chile with the description of Drosophila atacamensis sp.nov. Revista Chilena de Entomologia 15:37-60.

Caetano, S., Prado, D., Pennington, R., Beck, S., OLIVEIRA FILHO, A., Spichiger, R., and Naciri, Y. 2008. The history of seasonally dry tropical forests in eastern South America: inferences from the genetic structure of the tree Astronium urundeuva (Anacardiaceae). Molecular Ecology 17 (13):3147-3159. 
Carnaval, A. and Bates, J. 2007. Amphibian DNA shows marked genetic structure and tracks Pleistocene climate change in northeastern Brazil. Evolution 61 (12):2942-2957.

Carnaval, A. and Moritz, C. 2008. Historical climate modelling predicts patterns of current biodiversity in the Brazilian Atlantic forest. Journal of Biogeography 35 (7):1187-1201.

Carson, H. L. and Wasserman, M. 1965. A widespread chromosomal polymorphism in a widespread species, Drosophila buzzatii. The American Naturalist 99:111-115.

Clement, M., Posada, D., and Crandall, K. 2000. TCS: a computer program to estimate gene genealogies. Molecular Ecology 9 (10):1657-1659.

Da Silva, J. and Bates, J. 2002. Biogeographic patterns and conservation in the South American Cerrado: a tropical savanna hotspot. BioScience 52 (3):225-234.

De Brito, R. A., Manfrin, M. H., and Sene, F. M. 2002. Mitochondrial DNA phylogeography of Brazilian populations of Drosophila buzzatii. Genetics and Molecular Biology 25 (2):161-171.

De Brito, R. A. 2002. Nested cladistic analysis of Brazilian populations of Drosophila serido. Molecular Phylogenetics and Evolution 22 (1):131-143.

Drummond, A. and Rambaut, A. 2007. BEAST: Bayesian evolutionary analysis by sampling trees. BMC Evolutionary Biology 7 (1):214.

Drummond, A., Rambaut, A., Shapiro, B., and Pybus, O. 2005. Bayesian coalescent inference of past population dynamics from molecular sequences. Molecular biology and evolution 22 (5):1185.

Excoffier, L., Laval, G., and Schneider, S. 2005. Arlequin version 3.0: an integrated software package for population genetics data analysis. Evolutionary Bioinformatics Online 1:47-50.

Excoffier, L., Smouse, P. E., and Quattro, J. M. 1992. Analysis of molecular variance inferred from metric distances among DNA haplotypes: application to human mitochondrial DNA restriction data. Genetics 131:479-491.

Fielding, A. and Bell, J. 1997. A review of methods for the assessment of prediction errors in conservation presence/absence models. Environmental conservation 24 (01):38-49.

Figueiredo, V. and Sene, F. 1992. Chromosome variability in Brazilian populations of Drosophila buzzatii (Diptera, Drosophilidae). Rev. bras. biol 52 (4):555. 
Fontdevila, A., Ruiz, A., Alonso, G., and Ocaña, J. 1981. Evolutionary history of Drosophila buzzatii. I. Natural chromosomal polymorphism in colonized populations of the Old World. Evolution:148-157.

Fu, Y. and Li, W. 1993. Statistical tests of neutrality of mutations. Genetics 133 (3):693.

Gibbard, P. and Cohen, K. M. 2008. Global chronostratigraphical correlation table for the last 2.7 million years. Episodes 31 (2):4.

Giovanelli, J., Haddad, C., and Alexandrino, J. 2008. Predicting the potential distribution of the alien invasive American bullfrog (Lithobates catesbeianus) in Brazil. Biological Invasions 10 (5):585-590.

Haffer, J. 1969. Speciation in Amazonian forest birds. Science 165 (3889):131-137.

Hall, T. 1999. BioEdit: a user-friendly biological sequence alignment editor and analysis program for Windows 95/98/NT.

Hewitt, G. M. 2004. Genetic consequences of climatic oscillations in the Quaternary. Philosophical Transactions of the Royal Society of London, Series B: Biological Science 359:183-195.

Hijmans, R., Cameron, S., Parra, J., Jones, P., and Jarvis, A. 2005. Very high resolution interpolated climate surfaces for global land areas. International Journal of Climatology 25 (15):1965-1978.

Knowles, L. 2008. Why does a method that fails continue to be used? Evolution 62 (11):2713-2717.

Ledru, M., Ceccantini, G., Gouveia, S., López-Sáez, J., Pessenda, L., and Ribeiro, A. 2006. Millenial-scale climatic and vegetation changes in a northern Cerrado (Northeast, Brazil) since the Last Glacial Maximum. Quaternary Science Reviews 25 (9-10):1110-1126.

Ledru, M., Rousseau, D., and Cruz, F. 2005. Paleoclimate changes during the last $100,000 \mathrm{yr}$ from a record in the Brazilian Atlantic rainforest region and interhemispheric comparison. Quaternary Research 64 (3):444-450.

Librado, P. and Rozas, J. 2009. DnaSP v5: a software for comprehensive analysis of DNA polymorphism data. Bioinformatics 25 (11):1451.

Manel, S., Williams, H., and Ormerod, S. 2001. Evaluating presence-absence models in ecology: the need to account for prevalence. Journal of Applied Ecology 38 (5):921-931.

Manfrin, M. H. and Sene, F. M. 2006. Cactophilic Drosophila in South America: A model for evolutionary studies. Genética 126 (1-2):57-75. 
Mantel, N. 1967. The detection of disease clustering and a generalized regression approach. Cancer research 27 (2 Part 1):209.

Mayle, F., Beerling, D., Gosling, W., and Bush, M. 2004. Responses of Amazonian ecosystems to climatic and atmospheric carbon dioxide changes since the last glacial maximum. Philosophical Transactions of the Royal Society of London. Series B: Biological Sciences 359 (1443):499.

Moraes, E., Yotoko, K., Manfrin, M., Solferini, V., and Sene, F. 2009. Phylogeography of the cactophilic species Drosophila gouveai: demographic events and divergence timing in dry vegetation enclaves in eastern Brazil. Journal of Biogeography 36 (11):2136-2147.

Nagaraju, J. and Ranganath, H. 2004. Molecular phylogeny of the nasuta subgroup of Drosophila based on 12S rRNA, 16S rRNA and CoI mitochondrial genes, RAPD and ISSR polymorphisms. Genes \& Genetic Systems 79 (5):293-299.

Nei, M. 1987. Molecular Evolutionary Genetics: Columbia University Press.

Nielsen, R. and Beaumont, M. 2009. Statistical inferences in phylogeography. Molecular Ecology 18 (6):1034-1047.

Panchal, M. and Beaumont, M. 2007. The automation and evaluation of nested clade phylogeographic analysis. Evolution 61 (6):1466-1480.

Peck, D. and Congdon, B. 2004. Reconciling historical processes and population structure in the sooty tern Sterna fuscata. Journal of Avian Biology 35 (4):327335.

Pennington, R., Prado, D., and Pendry, C. 2000. Neotropical seasonally dry forests and Quaternary vegetation changes. Journal of Biogeography 27 (2):261-273.

Pereira, M. A. Q. R., Vilela, C. R., and Sene, F. M. 1983. Notes on breeding and feeding sites of some species of the repleta group of the genus Drosophila (Diptera, Drosophilidae). Ciência e Cultura 35:1313-1319.

Petit, R. 2008. The coup de grâce for the nested clade phylogeographic analysis? Molecular Ecology 17 (2):516-518.

Phillips, S., Anderson, R., and Schapire, R. 2006. Maximum entropy modeling of species geographic distributions. Ecological modelling 190 (3-4):231-259.

Posada, D., Crandall, K., and Templeton, A. 2000. GeoDis: a program for the cladistic nested analysis of the geographical distribution of genetic haplotypes. Molecular Ecology 9 (4):487-488. 
Prado, D. 2000. Seasonally dry forests of tropical South America: from forgotten ecosystems to a new phytogeographic unit. Edinburgh Journal of Botany 57 (03):437-461.

Prado, D. and Gibbs, P. 1993. Patterns of species distributions in the dry seasonal forests of South America. Annals of the Missouri Botanical Garden 80 (4):902927.

Rogers, A. and Harpending, H. 1992. Population growth makes waves in the distribution of pairwise genetic differences. Molecular biology and evolution 9 (3):552.

Rossi, M. S., Barrio, E., Latorre, A., QuezadaDiaz, J. E., Hasson, E., Moya, A., and Fontdevila, A. 1996. The evolutionary history of Drosophila buzzatii .30. Mitochondrial DNA polymorphism in original and colonizing populations. Molecular biology and evolution 13 (2):314-323.

Russo, C., Takezaki, N., and Nei, M. 1995. Molecular phylogeny and divergence times of drosophilid species. Molecular biology and evolution 12 (3):391.

Safford, D. 2007. Brazilian Páramos IV. Phytogeography of the campos de altitude. Journal of Biogeography 34 (10):1701-1722.

Schneider, S. and Excoffier, L. 1999. Estimation of past demographic parameters from the distribution of pairwise differences when the mutation rates vary among sites: application to human mitochondrial DNA. Genetics 152 (3):1079.

Smouse, P., Long, J., and Sokal, R. 1986. Multiple regression and correlation extensions of the Mantel test of matrix correspondence. Systematic Biology 35 (4):627.

Tajima, F. 1989. Statistical method for testing the neutral mutation hypothesis by DNA polymorphism. Genetics 123 (3):585.

Tamura, K., Dudley, J., Nei, M., and Kumar, S. 2007. MEGA4: molecular evolutionary genetics analysis (MEGA) software version 4.0. Molecular biology and evolution 24 (8):1596.

Taylor, N. and Zappi, D. 2004. Cacti of eastern Brazil. Kew: Royal Botanic Gardens, Kew xii, 499p.-col. illus.. ISBN 1842460560.

Templeton, A. 2004. Statistical phylogeography: methods of evaluating and minimizing inference errors. Molecular Ecology 13 (4):789-809.

Templeton, A. 2009. Why does a method that fails continue to be used? The answer. Evolution 63 (4):807-812. 
Templeton, A. R. 1998. Nested clade analyses of phylogeographic data: testing hypotheses about gene flow and population history. Molec. Ecol. 7:381-397.

Templeton, A. R., Routman, E., and Phillips, C. A. 1995. Separating population structure from population history: A cladistic analysis of the geographical distribution of mitochondrial DNA haplotypes in the tiger salamander, Ambystoma tigrinum. Genetics 140:767-782.

Thomas, R. and Barker, J. 1990. Breeding structure of natural populations of Drosophila buzzatii: effects of the distribution of larval substrates. Heredity 64:355-365.

Thomé, M., Zamudio, K., Giovanelli, J., Haddad, C., Baldissera Jr, F., and Alexandrino, J. 2010. Phylogeography of endemic toads and post-Pliocene persistence of the Brazilian Atlantic Forest. Molecular Phylogenetics and Evolution 55 (3):10181031.

Thompson, J., Higgins, D., and Gibson, T. 1994. CLUSTAL W: improving the sensitivity of progressive multiple sequence alignment through sequence weighting, position-specific gap penalties and weight matrix choice. Nucleic Acids Research 22 (22):4673.

Vanzolini, P. and Williams, E. 1970. South American anoles: the geographic differentiation and evolution of the Anolis chrysolepis species group (Sauria, Iguanidae).

Vilela, C., Sene, F., and Pereira, M. 1980. On the Drosophila fauna of Chaco and east slopes of the Andes in Argentina. Rev. bras. biol 40:837-841.

Vilela, C. R. 1983. A revision of the Drosophila repleta species group (Diptera: Drosophilidae). Revista Brasileira de Entomologia 27:1-114.

Vilela, C. R., Pereira, M. A. Q. R., and Sene, F. M. 1983. Preliminary data on the geographical distribution of Drosophila species within morphoclimatic domains in Brazil. II. The repleta group. Ciência e Cultura 35 (1):66-70.

Vilela, C. R., Sene, F. M., and Pereira, M. A. Q. R. 1980. On the Drosophila fauna of chaco and east slopes of the Andes in Argentina. Revista Brasileira de Biologia 40 (4):837-841.

Wang, M.-H., Lazebny, O., Harshman, L. G., and Nuzhdin, S. V. 2004. Environmentdependent survival of Drosophila melanogaster: a quantitative genetic analysis. Aging Cell 3 (3):133-140. 
Werle, E., Schneider, C., Renner, M., Völker, M., and Fiehn, W. 1994. Convenient single-step, one tube purification of PCR products for direct sequencing. Nucleic Acids Research 22 (20):4354.

Werneck, F. and Colli, G. 2006. The lizard assemblage from Seasonally Dry Tropical Forest enclaves in the Cerrado biome, Brazil, and its association with the Pleistocenic Arc. Journal of Biogeography 33 (11):1983-1992.

Yun-xin, F. 1997. Statistical tests of neutrality of mutations against population growth, hitchhiking and background selection. Genetics 147 (2).

Zeisset, I. and Beebee, T. 2008. Amphibian phylogeography: a model for understanding historical aspects of species distributions. Heredity 101 (2):109-119. 


\begin{tabular}{|c|c|c|c|}
\hline Location & State/Country & Longitude & Latitude \\
\hline 1- Junco do Seridó & PB-Brazil & -36.702222 & -7.006944 \\
\hline 2- Campina Grande & PB-Brazil & -35.671389 & -7.259722 \\
\hline 3- Exu & PE-Brazil & -39.983333 & -7.983333 \\
\hline 4- Juazeiro & BA-Brazil & -40.500000 & -9.416667 \\
\hline 5- Morro Torre & BA-Brazil & -40.250000 & -9.933333 \\
\hline 6- Xique-Xique & BA-Brazil & -42.716667 & -10.866667 \\
\hline 7- Irecê & BA-Brazil & -41.783333 & -11.333333 \\
\hline 8- Morro do Chapéu & BA-Brazil & -41.168889 & -11.548889 \\
\hline 9- Ibotirama & BA-Brazil & -43.066667 & -12.266667 \\
\hline 10- Milagres & BA-Brazil & -39.883333 & -12.850000 \\
\hline 11- Salvador & BA-Brazil & -38.450000 & -12.950000 \\
\hline 12- Manoel Vitorino & BA-Brazil & -40.233333 & -14.133333 \\
\hline 13- Cardeal Mota & MG-Brazil & -43.583333 & -19.283333 \\
\hline 14- Nova Ponte & MG-Brazil & -47.683333 & -19.133333 \\
\hline $\begin{array}{l}\text { 15- Morro Chapéu } \\
\text { MG }\end{array}$ & MG-Brazil & -47.383333 & -20.050000 \\
\hline 16- Estreito & MG-Brazil & -47.266667 & -20.150000 \\
\hline 17- Furnas & MG-Brazil & -46.250000 & -20.616667 \\
\hline 18- Altinópolis & SP-Brazil & -47.900000 & -21.100000 \\
\hline 19- Sertãozinho & SP-Brazil & -47.966667 & -21.150000 \\
\hline 20- Cajuru & SP-Brazil & -47.266667 & -21.300000 \\
\hline 21- São Simão & SP-Brazil & -47.550000 & -21.466667 \\
\hline 22- Brotas & SP-Brazil & -47.950000 & -22.283333 \\
\hline 23- Itirapina & SP-Brazil & -47.800000 & -22.266667 \\
\hline 24- Piracicaba & SP-Brazil & -47.683333 & -22.716667 \\
\hline 25- Itatiba & SP-Brazil & -46.838889 & -23.005833 \\
\hline 26- Serra Japi & SP-Brazil & -46.950000 & -23.233333 \\
\hline 27- Ibiuna & SP-Brazil & -47.200000 & -23.733333 \\
\hline 28- Sorocaba & SP-Brazil & -47.566667 & -23.500000 \\
\hline 29- Sengés & PR-Brazil & -49.483333 & -24.083333 \\
\hline 30- Tibagi & PR-Brazil & -50.415278 & -24.513611 \\
\hline 31- Florianópolis & SC-Brazil & -48.421111 & -27.573333 \\
\hline 32- Arroio Teixeira & RS-Brazil & -49.933333 & -29.633333 \\
\hline 33- Capão da Canoa & RS-Brazil & -50.047500 & -29.758611 \\
\hline 34- Osório & RS-Brazil & -50.166667 & -29.883333 \\
\hline 35- Tramandaí & RS-Brazil & -50.216667 & -29.916667 \\
\hline 36- Santiago & RS-Brazil & -54.833333 & -29.183333 \\
\hline 37- Guaritas & RS-Brazil & -53.333056 & -30.748889 \\
\hline 38- Cordoba & Argentina & -64.400000 & -31.400000 \\
\hline 39- La Cruz & Argentina & -64.491944 & -32.307222 \\
\hline 40- San Luis & Argentina & -66.300000 & -33.270000 \\
\hline 41- San Raphael & Argentina & -68.210000 & -34.450000 \\
\hline 42- San Juan & Argentina & -68.410000 & -31.450000 \\
\hline 43- Vale Fertil & Argentina & -67.474722 & -30.633056 \\
\hline 44- Cochabamba & Bolivia & -66.120000 & -17.350000 \\
\hline
\end{tabular}




\begin{tabular}{|l|l|l|l|l|l|l|l|}
\hline \multicolumn{7}{|l|}{ Table 2. Genetic Diversity index and Neutrality tests results of Drosophila buzzatii species. } \\
\hline Biomes & $\mathrm{n}$ & \multicolumn{1}{l|}{ Diversity index } & \multicolumn{1}{l|}{ Neutrality Index } & \\
\hline & & $h$ & $\mathrm{p}$ & Tajima's D & Fu's Fs & $\mathrm{D}^{*}$ & $\mathrm{~F}^{*}$ \\
\hline Caatinga & 34 & 0.8039 & 0.0030 & -1.1325 & $-6.4022^{* *}$ & $-1,234$ & $-1,432$ \\
\hline Cerrado & 31 & 0.6215 & 0.0020 & $-1.9577^{* *}$ & $-4.9310^{* *}$ & -1.596 & -2.001 \\
\hline Atlantic Forest & 32 & 0.4899 & 0.0019 & $-2.3538^{*}$ & $-5.7081^{* *}$ & $-3.079^{*}$ & $-3.257^{*}$ \\
\hline $\begin{array}{l}\text { Atlantic Forest } \\
\text { NE }\end{array}$ & 2 & 0.0000 & 0.0000 & 0.0000 & NA & NA & NA \\
\hline Pampa & 14 & 0.3956 & 0.0011 & $-1.7976^{*}$ & -1.1512 & $-2.274^{*}$ & $-2.449^{*}$ \\
\hline Chaco & 19 & 0.3860 & 0.0004 & -1.5108 & $-3.5706^{* *}$ & -1.658 & $-1,797$ \\
\hline Total & 132 & 0.6192 & 0.0022 & $-2.4150^{* *}$ & $-28.6719^{* *}$ & $-3.889^{*}$ & $-3.959^{*}$ \\
\hline
\end{tabular}

* Significant results to alpha $=0.05$

$* *$ Significant results to alpha $=0.01$

\begin{tabular}{|l|l|l|l|l|}
\hline \multicolumn{6}{|l|}{ Table 3. AMOVA results. Samples grouped by Biomes. } \\
\hline $\begin{array}{l}\text { Source of } \\
\text { variation }\end{array}$ & d.f. & Sum of squares & $\begin{array}{l}\text { Variance } \\
\text { components }\end{array}$ & $\begin{array}{l}\text { Percentage of } \\
\text { variation }\end{array}$ \\
\hline Among groups & 5 & 10.491 & $0.0463 \mathrm{Va}$ & 7.48 \\
\hline $\begin{array}{l}\text { Among } \\
\text { populations } \\
\text { within groups }\end{array}$ & 35 & 31.573 & $0.1764 \mathrm{Vb}$ & 28.49 \\
\hline $\begin{array}{l}\text { Within } \\
\text { populations }\end{array}$ & 86 & 34.103 & $0.3966 \mathrm{Vc}$ & 64.04 \\
\hline Total & 126 & 76.167 & & NA \\
\hline
\end{tabular}

$\Phi_{\mathrm{SC}}: 0.3079 \mathrm{p}<0.01$

$\Phi_{\mathrm{ST}}: 0.3597 \mathrm{p}<0.01$

$\Phi_{\text {СТ }}: 0.0748 \mathrm{p}<0.05$

Table 4. Fst values, in the left diagonal values of Fst from all Biomes, in the right $\mathrm{p}$ values from the Fst in Bold.

\begin{tabular}{|c|c|c|c|c|c|c|}
\hline Biome & Chaco & Pampa & $\begin{array}{c}\text { Atlantic } \\
\text { Forest }\end{array}$ & $\begin{array}{c}\text { Atlantic } \\
\text { Forest NE }\end{array}$ & Cerrado & Caatinga \\
\hline Chaco & 0.0000 & $\mathbf{0 . 1 4 4 1}$ & $\mathbf{0 . 9 8 1 9}$ & $\mathbf{0 . 0 0 0 0} *$ & $\mathbf{0 . 3 8 7 4}$ & $\mathbf{0 . 0 0 0 0 *}$ \\
\hline Pampa & 0.0097 & 0.0000 & $\mathbf{0 . 6 0 3 6}$ & $\mathbf{0 . 0 5 4 0}$ & $\mathbf{0 . 7 0 2 7}$ & $\mathbf{0 . 0 0 0 0} *$ \\
\hline $\begin{array}{c}\text { Atlantic } \\
\text { Forest }\end{array}$ & -0.0143 & -0.0055 & 0.0000 & $\mathbf{0 . 1 0 8 1}$ & $\mathbf{0 . 1 1 7 1}$ & $\mathbf{0 . 0 0 0 0 *}$ \\
\hline $\begin{array}{c}\text { Atlantic } \\
\text { Forest NE }\end{array}$ & 0.8266 & 0.6209 & 0.4149 & 0.0000 & $\mathbf{0 . 0 2 7 0} *$ & $\mathbf{0 . 0 2 7 0 *}$ \\
\hline Cerrado & 0.0063 & -0.0105 & 0.0092 & 0.3749 & 0.0000 & $\mathbf{0 . 0 0 0 0 *}$ \\
\hline Caatinga & 0.1944 & 0.1665 & 0.1384 & 0.3554 & 0.1688 & 0.0000 \\
\hline
\end{tabular}

* Significant results to alpha $=0.05$ 
Table 5. Results from the NCPA analyses interpreted by the inference key in Templeton 2004.

\begin{tabular}{|l|l|l|}
\hline Sample/Clade & Key steps & Conclusion \\
\hline Haplotype 20 & $1-2-3-4-N o$ & $\begin{array}{l}\text { Restricted gene flow with } \\
\text { isolation by distance. }\end{array}$ \\
\hline Clade 1-2 & $\begin{array}{l}\text { Restricted gene flow/dispersal } \\
\text { but with some } \\
\text { long-distance dispersal. }\end{array}$ \\
\hline Clade 1-3 & $\begin{array}{l}\text { Restricted gene flow with } \\
\text { isolation by distance. }\end{array}$ \\
\hline Clade 2-1 & $\begin{array}{l}\text { Restricted gene flow with } \\
\text { isolation by distance. }\end{array}$ \\
\hline
\end{tabular}

Table 6. Migrate results using no geofile and no restriction of dispersion for all Biomes. The number represents the Effective number of migrants per generation and Biomes with the "+" symbol are receiving Biomes.

\begin{tabular}{|l|l|l|l|l|l|l|}
\hline Biomes & Caatinga+ & Cerrado+ & $\begin{array}{l}\text { Atlantic } \\
\text { Forest NE }+\end{array}$ & $\begin{array}{l}\text { Atlantic } \\
\text { Forest }+\end{array}$ & Pampa+ & Chaco $^{+}$ \\
\hline Caatinga & - & 0.000 & $2.10 \mathrm{e}^{3}$ & 0.000 & 0.000 & 0.000 \\
\hline Cerrado & 242.96 & - & 403.09 & 0.000 & $2.19 \mathrm{e}^{3}$ & 0.000 \\
\hline $\begin{array}{l}\text { Atlantic } \\
\text { Forest NE }\end{array}$ & 173.11 & 207.51 & - & 0.000 & 0.000 & 0.000 \\
\hline $\begin{array}{l}\text { Atlantic } \\
\text { Forest }\end{array}$ & 0.000 & 966.52 & 0.000 & - & 0.000 & $2.67 \mathrm{e}^{3}$ \\
\hline Pampa & 0.000 & 0.000 & 107.23 & 0.000 & - & 0.000 \\
\hline Chaco & 0.000 & 0.000 & 0.000 & $1.23 \mathrm{e}^{3}$ & $1.02 \mathrm{e}^{3}$ & - \\
\hline
\end{tabular}




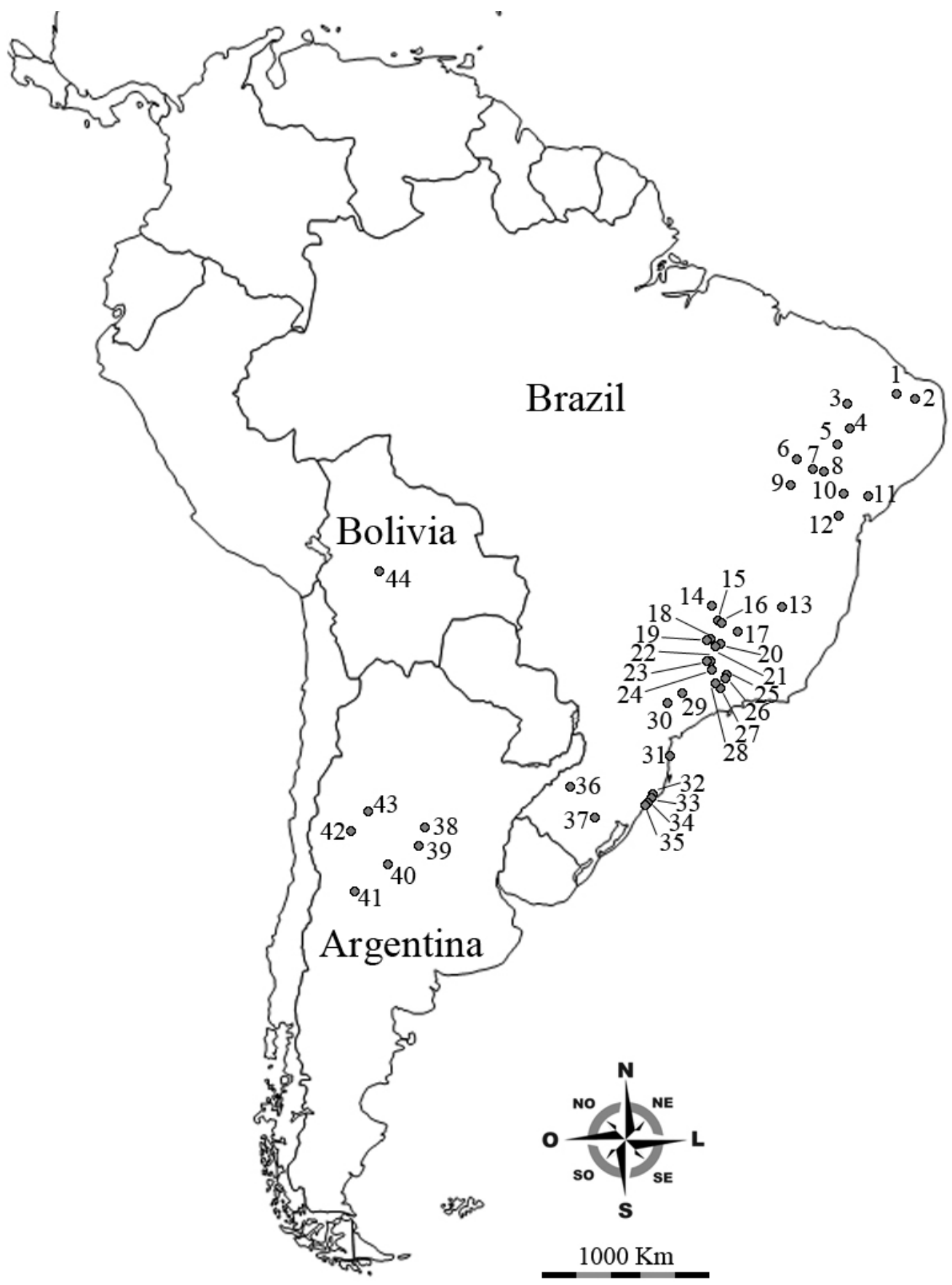

Figure 1. The samples locations of $D$. buzzatii individuals along their natural distribution in South America. 


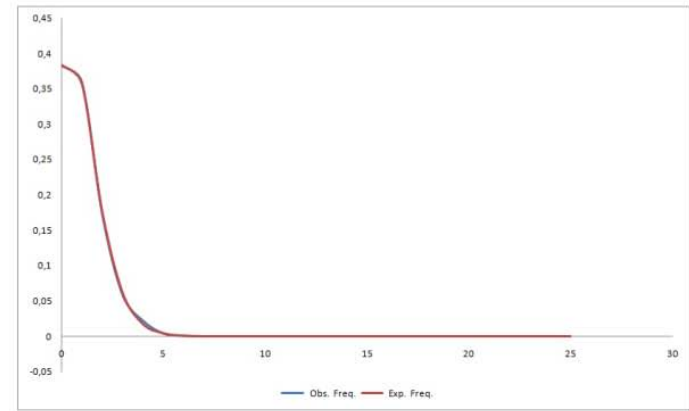

D. buzzatii especies

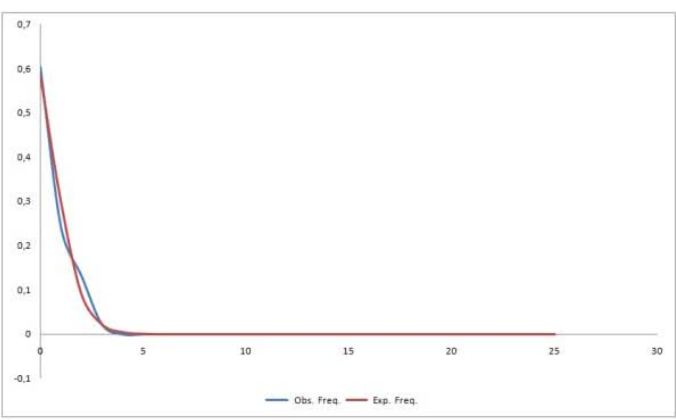

Pampas

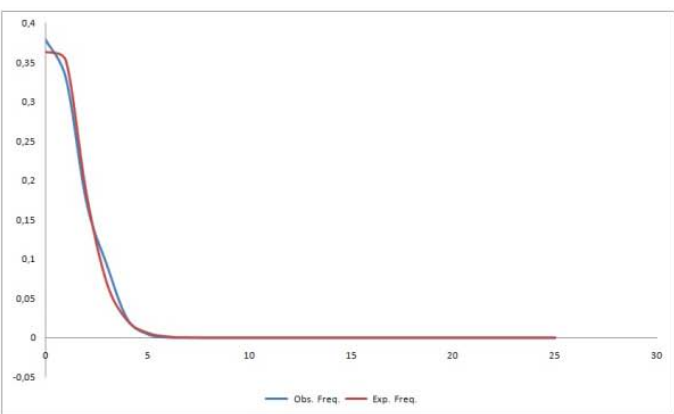

Cerrado

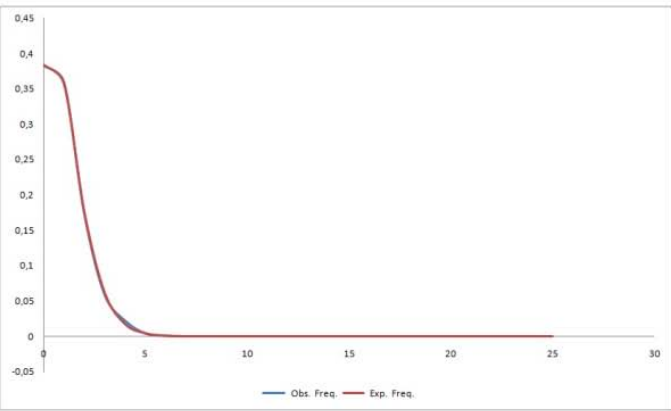

Chaco

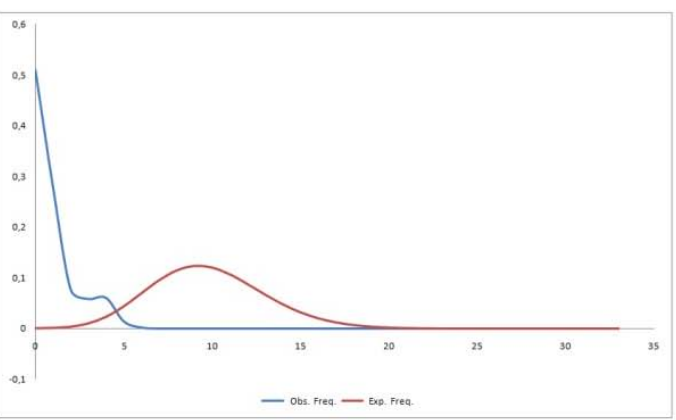

Atlantic Forest

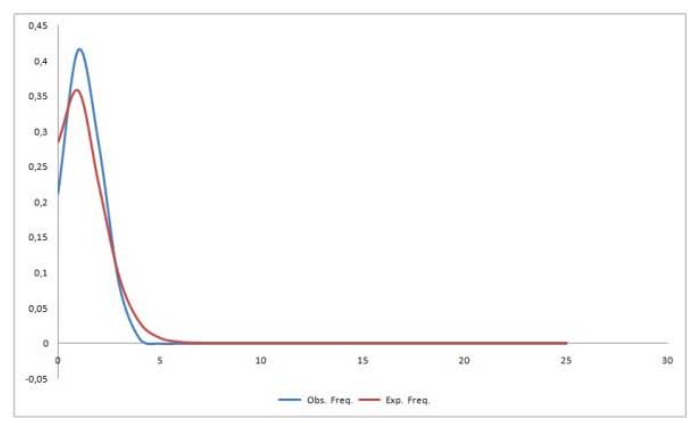

Caatinga

Figure 2. Mismatch distribution of $D$. buzzatii species. In left high corner distribution for the species and subdivided by Ecological Domain. Red curves represent the expected frequencies and the Blue curves the observed frequencies. Unimodal distribution is an indicative of population expansion event. 


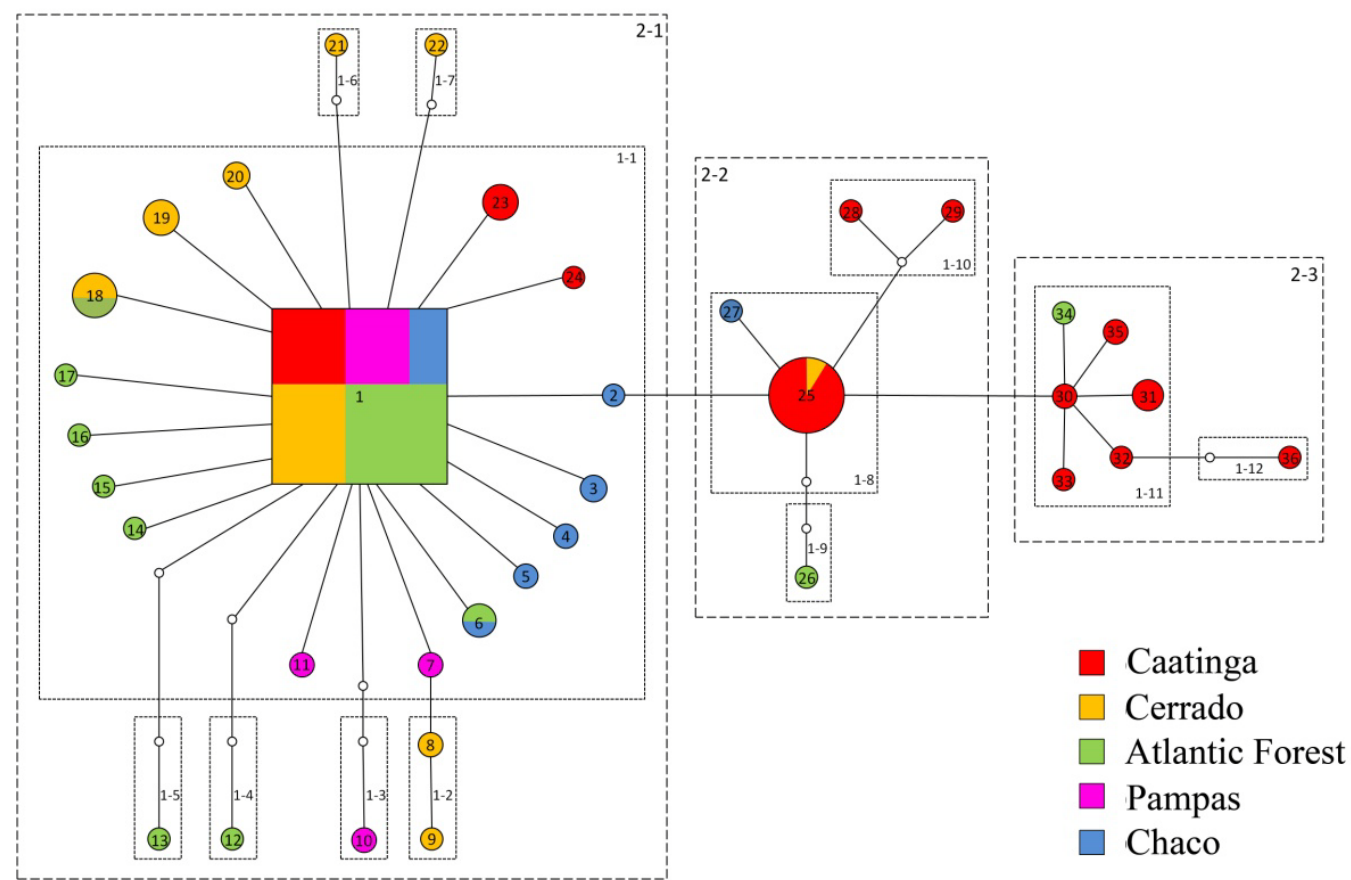

Figure 3. Haplotype network generate by the TCS program. The circles are proportional of the frequence of sequences. The rectangle represent the ancestral haplotype. The colors represents the Domains sampled. 
Apêndice 4

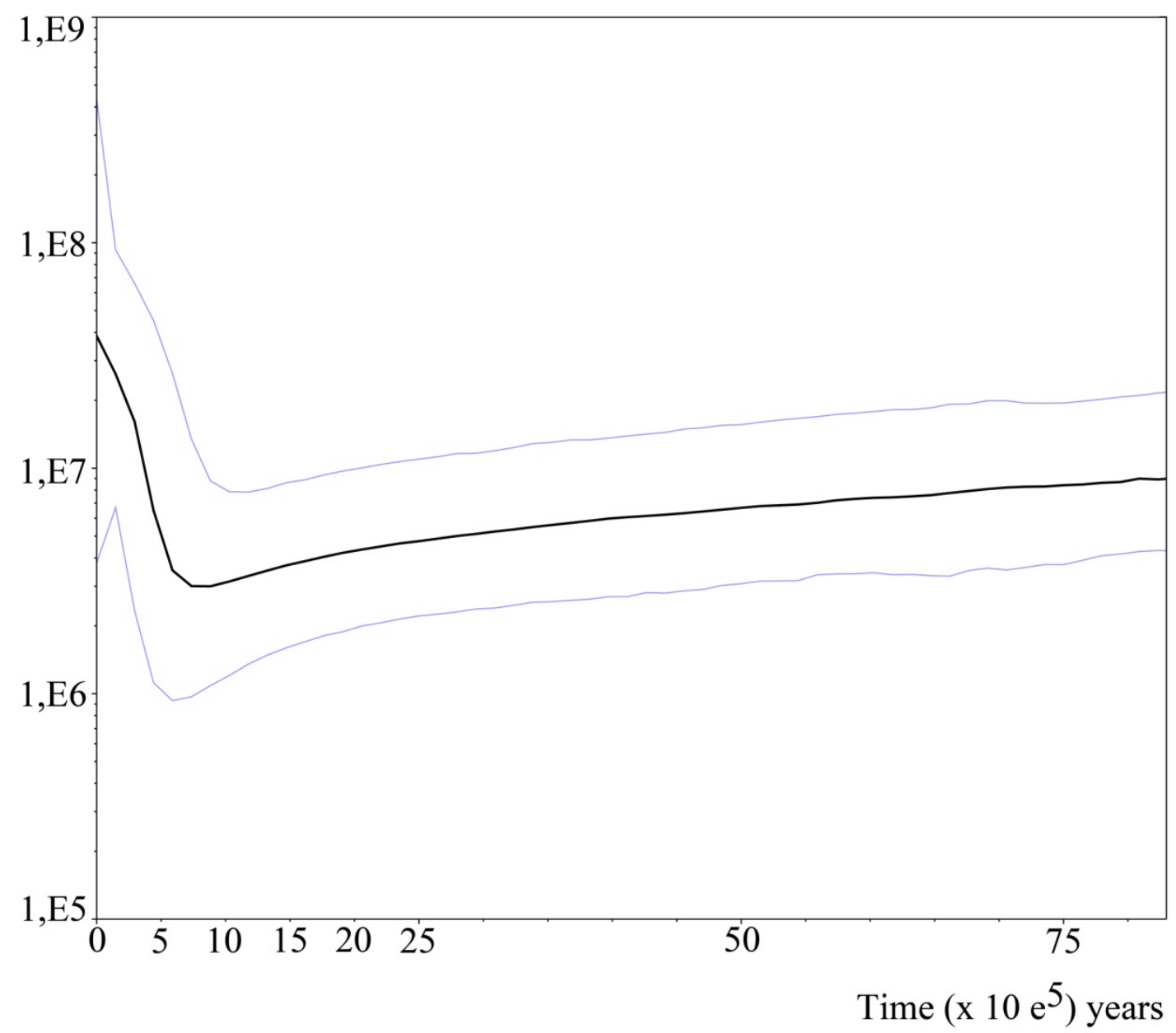

Figure 4. The BSP curve representing the population growth in time. 


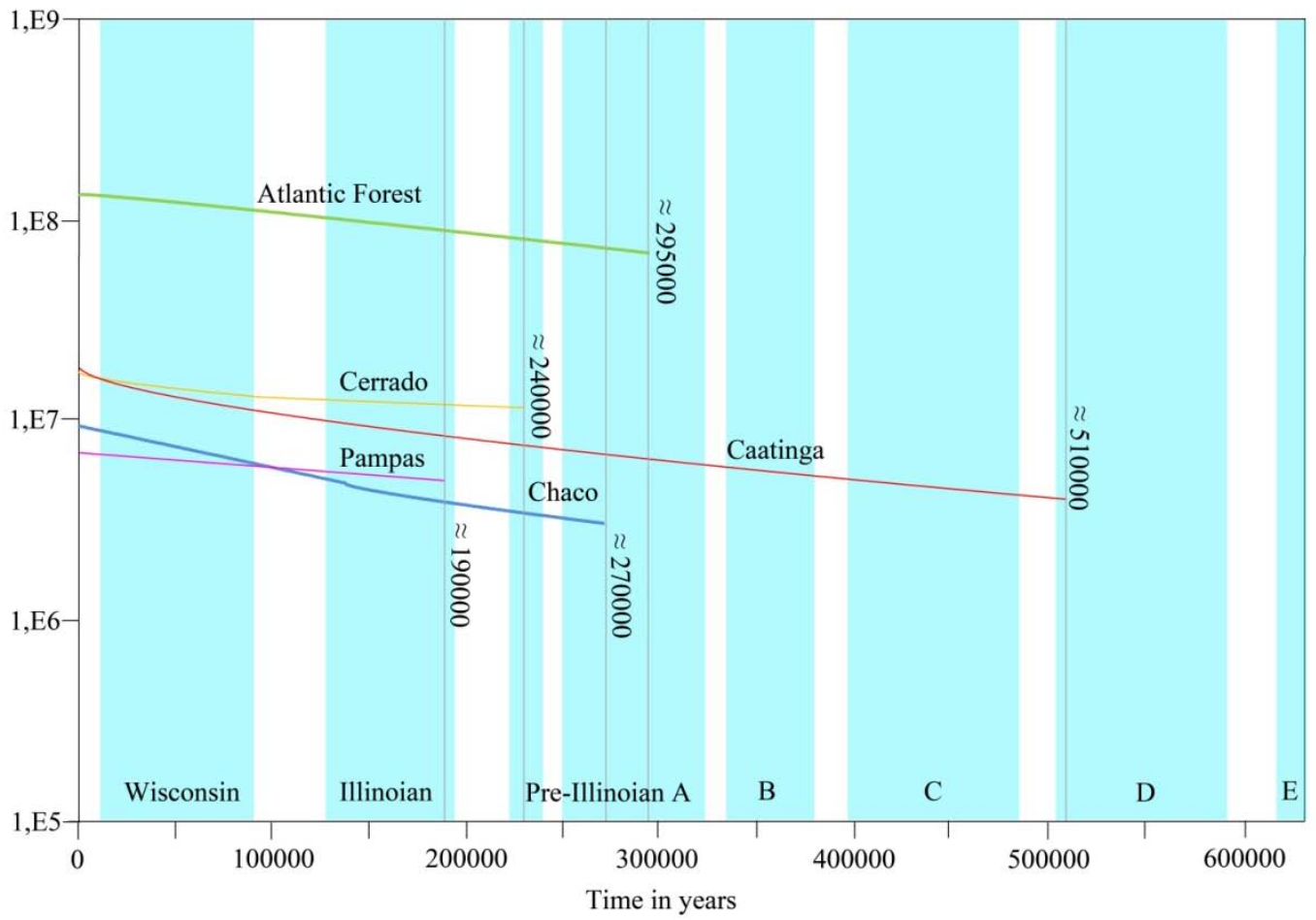

Figure 5. BSP generated by Domain. The numbers represent the estimated time of expansion by every domain. Blue columns represent possible glaciation events. 
Apêndice 4

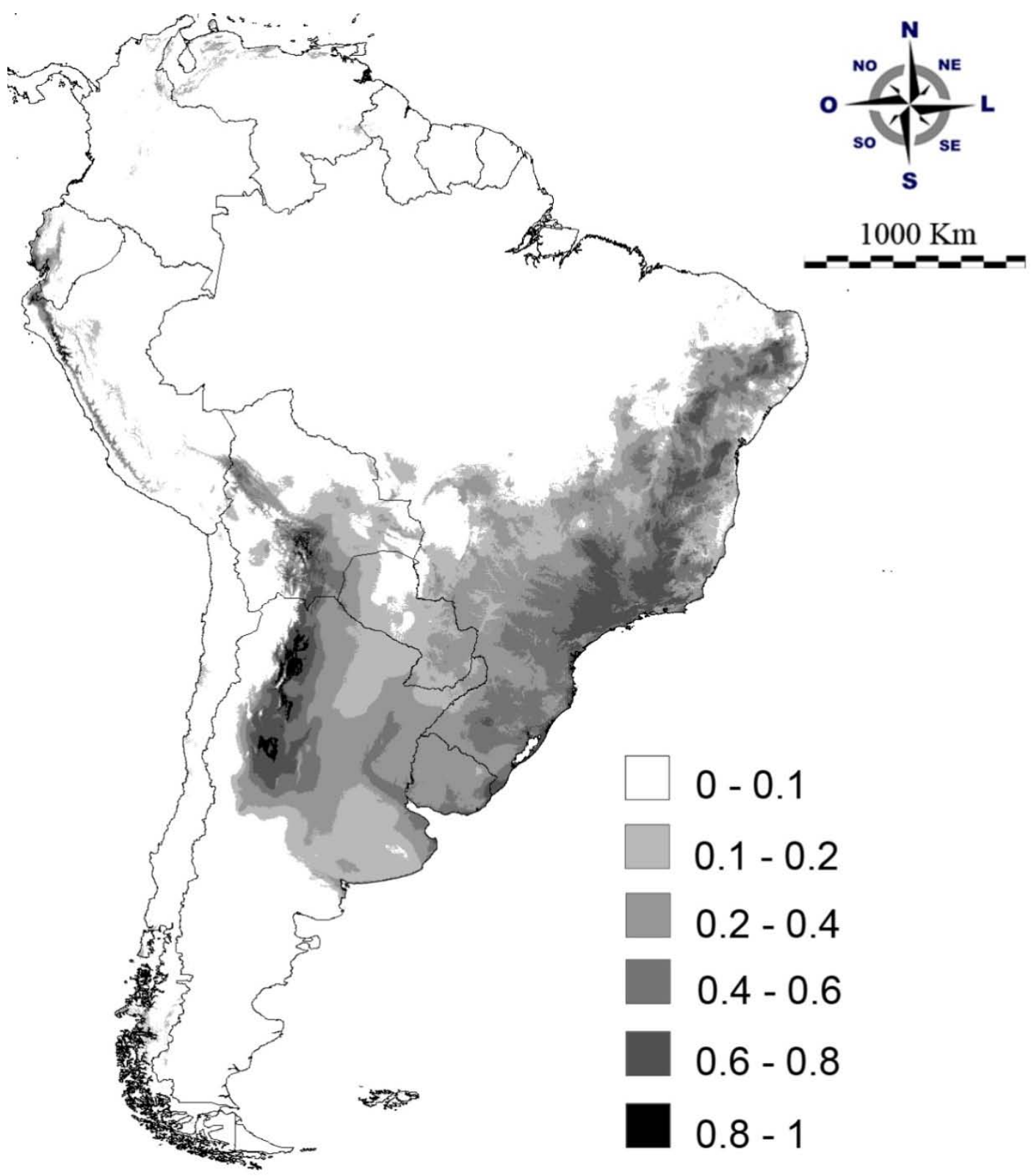

Figure 6. Current modeling distribution of $D$. buzzatii generated by the MaxEnt program. The gray scale represent the probability of presence of the species. 
Apêndice 4

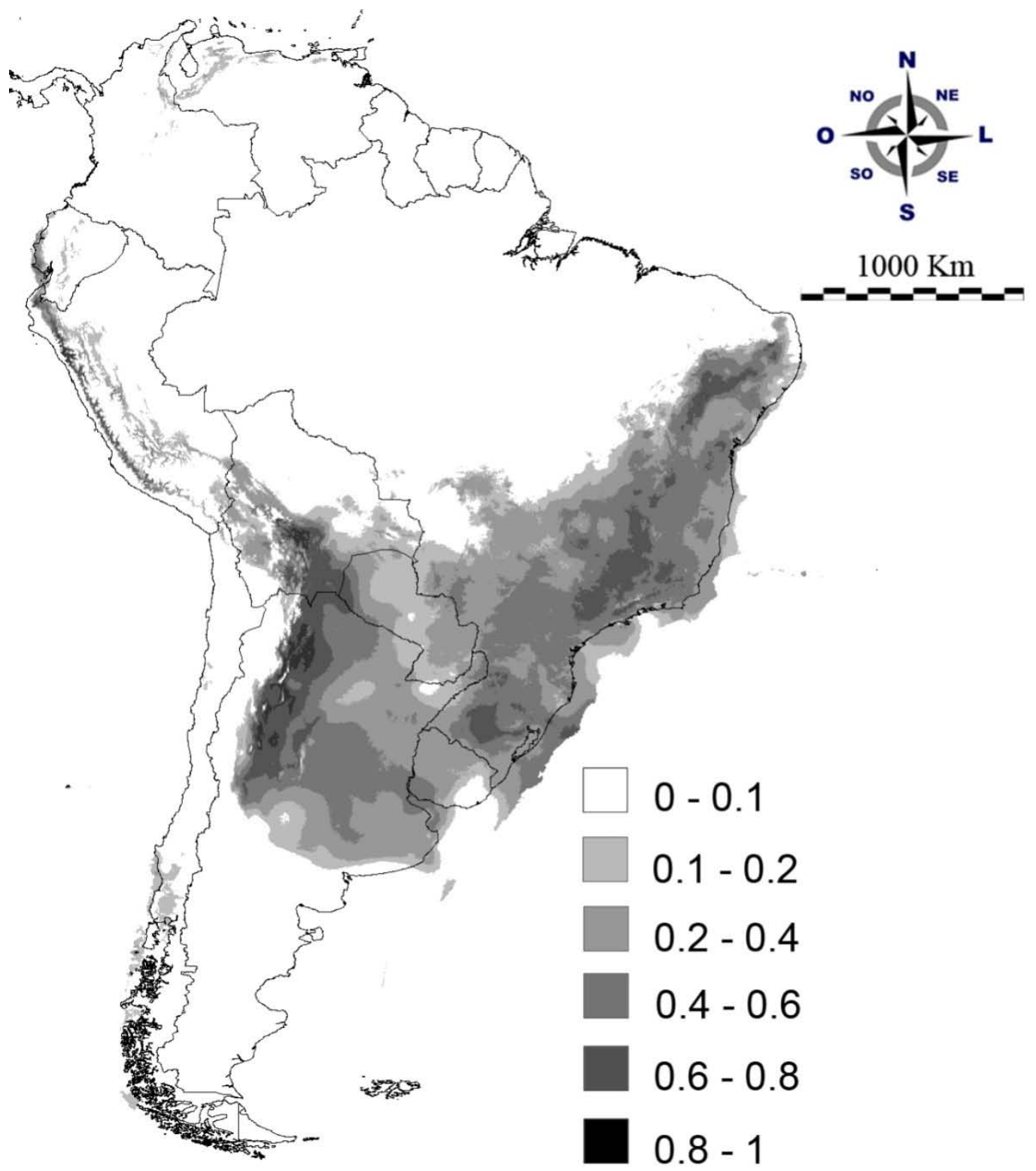

Figure 7. Past representation of distribution of $D$. buzzatii based in the estimations of the CCSM model for $\mathbf{2 1 . 0 0 0}$ years ago. The gray scale represent the probability of presence of the species. 


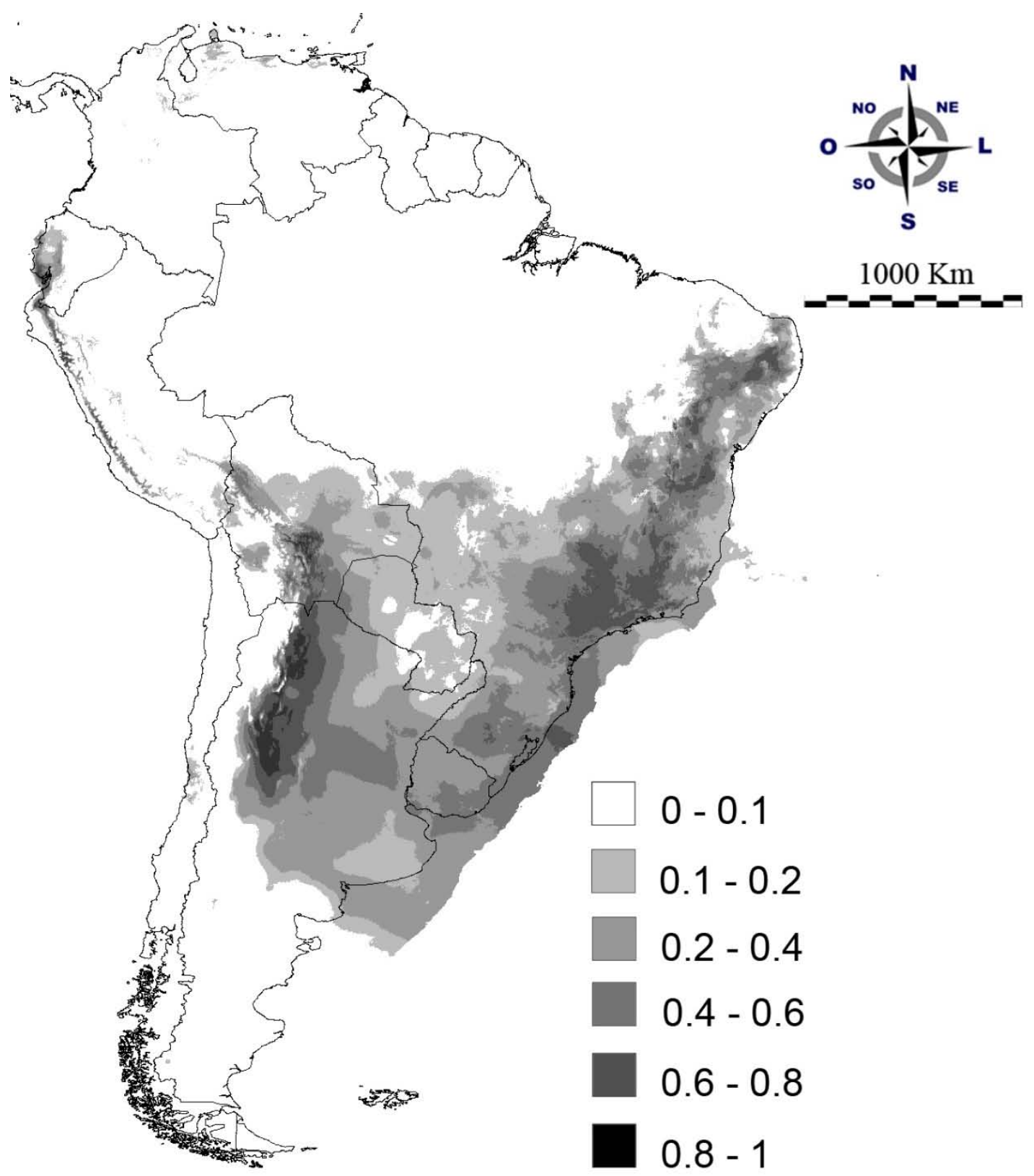

Figure 8. Past representation of distribution of $D$. buzzatii based in the estimations of the MIROC model for 21.000 years ago. The gray scale represent the probability of presence of the species. 


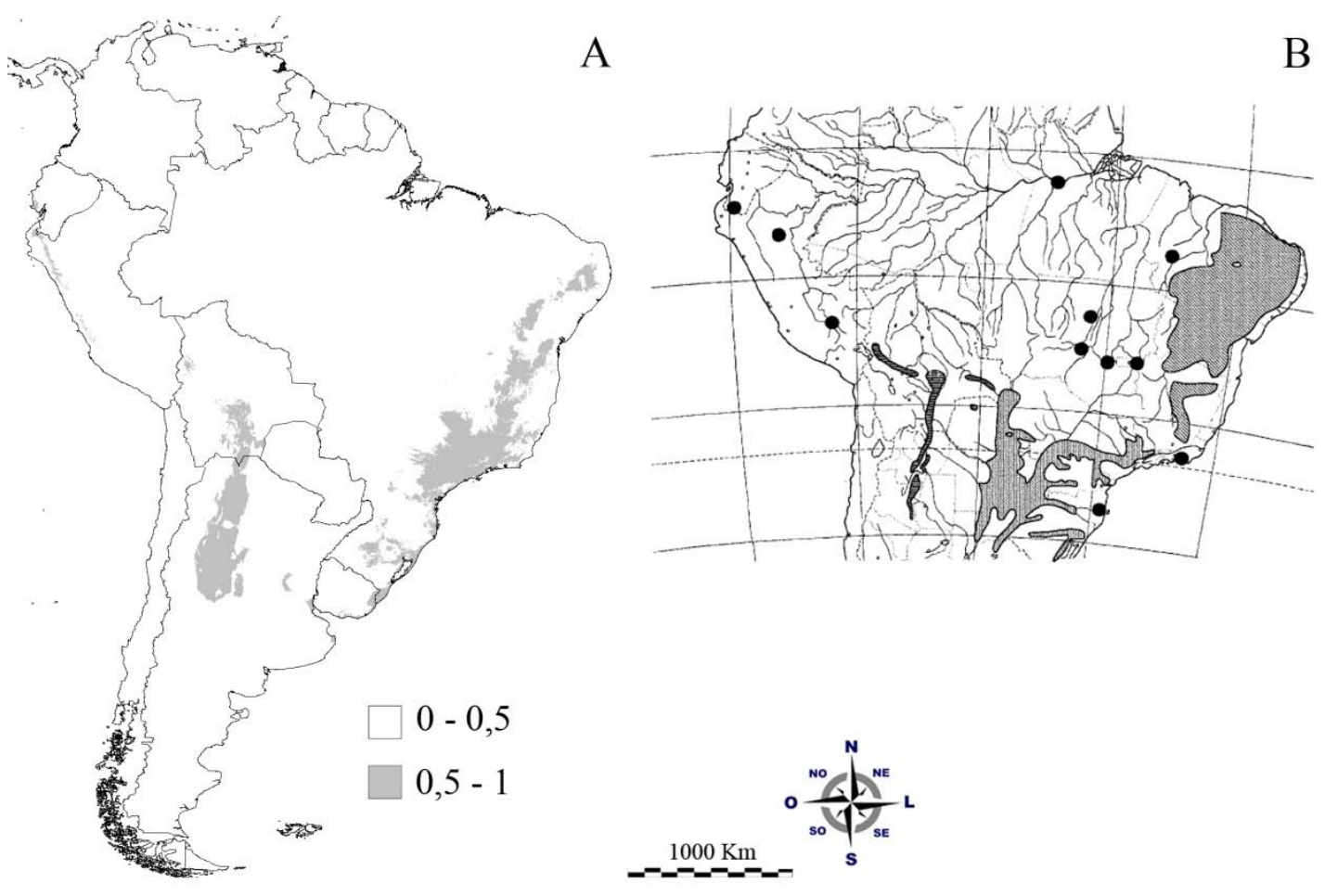

Figure 9. A. Current modeling of presence distribution for the $D$. buzzatii species with high threshold values of 0.5. B. Map of probable distribution of Tropical Seasonal Forests Regions of South America, modified by Prado, 2000. 